UNIVERSIDADE DE SÃO PAULO

INSTITUTO DE PSICOLOGIA

\title{
LISETE BARLACH
}

A criatividade humana sob a ótica do empreendedorismo inovador

São Paulo

2009 


\section{LISETE BARLACH}

\section{A criatividade humana sob a ótica do empreendedorismo inovador}

Tese apresentada ao Instituto de Psicologia da Universidade de São Paulo para obtenção do título de Doutor em Psicologia

Área de Concentração: Psicologia Social

Orientador: Prof. Dr. Sigmar Malvezzi

São Paulo

2009 
AUTORIZO A REPRODUÇÃO E DIVULGAÇÃO TOTAL OU PARCIAL DESTE TRABALHO, POR QUALQUER MEIO CONVENCIONAL OU ELETRÔNICO, PARA FINS DE ESTUDO E PESQUISA, DESDE QUE CITADA A FONTE.

Catalogação na publicação

Biblioteca Dante Moreira Leite

Instituto de Psicologia da Universidade de São Paulo

Barlach, Lisete.

A criatividade humana sob a ótica do empreendorismo inovador / Lisete Barlach; orientador Sigmar Malvezzi. -- São Paulo, 2009.

278 p.

Tese (Doutorado - Programa de Pós-Graduação em Psicologia. Área de Concentração: Psicologia Social) - Instituto de Psicologia da Universidade de São Paulo.

1. Criatividade 2. Empreendedorismo 3. Inovação 4. Causalidade Pessoal 5. Resiliência (Psicologia) I. Título. 


\section{Agradecimentos}

Ao Prof. Sigmar Malvezzi, modelo de professor e profissional que, durante o mestrado, eu aprendi a admirar - descontração no momento certo e rigor no que é necessário - e que, ao longo deste doutorado, teve a paciência de tolerar a minha inquietação e a minha ansiedade, sempre transmitindo serenidade. Agradeço as críticas às várias versões deste texto que contribuíram para seu aprimoramento e para aumentar a minha compreensão sobre o assunto.

Ao Prof. John F. Cabra, que, em Buffalo (NY), me introduziu à melhor biblioteca (que já conheci) sobre criatividade, além de ter me recebido de forma acolhedora como sua orientanda brasileira.

À Jô Yudess, que tão carinhosamente, me relatou a percepção de uma americana sobre o Brasil e, descontraidamente, ministrou uma aula sobre o fator intercultural na criatividade.

Ao International Center for Creative Studies, representados pelos docentes: John F. Cabra, Jô Yudess, Gerard Puccio e Michael Fox. Muito obrigada pela oportunidade de conhecer e conviver com vocês!

À Leia Maria Cardenuto, amiga de todas as horas e situações.

Ao Prof. Marcos Nogueira Martins (Marcão), que muito contribuiu com a revisão do texto apresentado ao II International Congress of Creativity and Innovation. 
À Adriana Albertal, pela revisão em inglês e espanhol e, mais do que tudo, pela amizade e pelos momentos de crescimento pessoal.

Ao Emílio Terron, que me ajudou sobremaneira com a revisão desta tese.

Ao Ítalo Minello, que conhece e pratica o sentido verdadeiro da amizade.

Ao Paulo Emílio Alves, colega de momentos de descontração, seriedade e aprendizado.

À K, mestre e orientador, pelo reencontro e pela oportunidade de convivência. 


\section{Prefácio}

Escrever uma tese é, em si mesmo, um ato criativo. Utilizo aqui da primeira pessoa para descrever alguns processos que, vivenciados, tornaram-se subsídios para o estudo, objeto desta tese. Dentre os temas que adquiriram um colorido especial em função da vivência pessoal estão a criatividade, a pessoa criativa e o empreendedorismo.

Poder-se-ia perguntar por que incluir o empreendedorismo no rol desses temas. A resposta está em que, entre o sonho de escrever a tese e a concretização desse projeto, foi necessária uma boa dose de atitude empreendedora e de crença na causalidade pessoal, nas palavras de De Charms (1968).

Quando comecei a pensar no objeto da tese, encantei-me pelo tema da criatividade humana. Naquele momento, esse interesse era tão vasto que poderia abranger tudo, o mundo inteiro, qualquer objeto ou situação. Ao longo do percurso, percebi que, sem estabelecer um foco, dificilmente eu conseguiria chegar a empreender este estudo. Delimitar o tema, abrir mão de querer abarcar tudo, exigiu a elaboração de muitos lutos internos. Esse é um primeiro aspecto que demanda reflexão: criar é também renunciar, especialmente no plano da abrangência.

Nesse caminho, também foi possível compreender, do ponto de vista vivencial, a tensão “criação - mercado", a necessidade de considerar que o produto da criação - a tese - será submetida a agentes do reconhecimento que analisarão a originalidade, a consistência interna e outros quesitos. Isso coloca qualquer pessoa que crie diante da questão: escrever para o público leitor (avaliador) ou "empenhar-se na perfeição interna de sua obra, 
independentemente do sufrágio que o público dedicará àquela"? O tipo de impacto que tal questão suscita na pessoa que cria poderá ser determinante da qualidade da obra.

Ao longo do percurso, tive muitas experiências de serendipidade: momentos em que, inesperadamente, soluções arduamente buscadas se apresentavam e eu sentia a urgência de não perdê-las. Como descrito nesta tese, esses momentos ocorrem, geralmente, entre a atividade e o repouso. No meu caso, tive que deixar um bloco de notas na cabeceira da cama, pois antes de "pegar no sono" as idéias apareciam e eu temia não mais recuperá-las na manhã seguinte.

Tenho agora a convicção, apoiada numa vivência, de que a elaboração criativa é um processo de auto-realização. Concluir a tese - produto único, singular, original -, entregála, submetê-la à crítica de uma banca e - assim espero - ser aprovada, representa, para mim, competir com um padrão de excelência interiorizado. Como qualquer outro (a) autor (a), envolvi-me neste trabalho com paixão o que, nas palavras de Cardon et al. (2009), relaciona-se positivamente à motivação, à tenacidade, ao desejo de trabalhar por muitas horas, à coragem e aos altos níveis de iniciativa e persistência frente a obstáculos.

Instantes antes de concluir esta tese, senti na pele o peso restritivo / obstaculizador da burocracia com relação ao criar. Como toda tese na Universidade de São Paulo, esta também necessitava de uma ficha catalográfica fornecida pela biblioteca da unidade à qual estou vinculada. Qual não foi a minha surpresa ao receber uma mensagem informando que criatividade e inovação são sinônimos e, portanto, não podem ser elencadas juntas como palavras-chave? Tanto tempo para tentar descaracterizar esta falsa sinonimia... 


\section{A criatividade humana sob a ótica do empreendedorismo inovador}

\section{Resumo}

O presente trabalho investiga a criatividade no contexto da inovação nas organizações. Em diversos campos da vida humana a criatividade tem sido uma questão relevante, em função da complexidade das soluções exigidas em situações e ambientes marcados pelas incertezas, ausência de modelos ou paradigmas e falência de outros. Na esfera dos negócios e das organizações é exatamente esta ambiência que caracteriza o cenário atual, onde predomina a demanda por inovação como fator competitivo. A criatividade surge, então, como força motriz para as inovações, fundamento de sua qualidade e fator diferencial frente aos desafios e problemas do cotidiano e dos negócios. Entendida como potencialidade sempre presente no ser humano, quando aliada à atitude e à ação empreendedora, a criatividade é capaz de contribuir para a inovação. A relação entre criatividade e inovação é aqui estudada, tendo como foco da análise a gênese de empreendimentos inovadores, pois, embora seja conhecida a necessidade de inovar, as organizações devem lidar permanentemente com a chamada ambidestria organizacional, caracterizada como a simultaneidade da manutenção e da inovação de seu negócio. Mesmo reconhecendo necessidade de inovação para garantir o sucesso dos negócios, sua implementação depende da legitimação por parte dos agentes de reconhecimento e sua viabilização, de contextos burocráticos, resistentes e cegos. A investigação foi apoiada em estudo empírico, que teve como sujeitos pessoas que tiveram projetos criativos recusados pelas organizações em que trabalhavam e que, sem abandonar suas idéias, criaram empresas próprias, revelando, nesse processo, a criatividade pessoal, a resiliência, o empreendedorismo e a causalidade pessoal. 
Palavras-chave: criatividade, inovação, empreendedorismo, resiliência, causalidade pessoal. 


\title{
Human creativity seen through innovative entrepreneurship lens
}

\begin{abstract}
This thesis aims at investigating creativity within the context of innovation in organizations. Creativity is a relevant issue in several realms of human life if the requirements stemming from situations and environments characterized by uncertainties, lack or failure of paradigms and models are concerned. This is the prevailing status of innovation nowadays, a condition of competition. Creativity emerges as crucial element of innovation, rooting its quality and differentiating its outcomes. Understood as a potential ever present in human beings, creativity when aligned with entrepreneurship is enabled to contribute to innovation. Here, the relationship between creativity and innovation is scrutinized through the lens of the genesis of innovative entrepreneurship since the recognition of the need of innovation does not free organizations from the manning of the traditional and the new - organizational ambidextry. Although the recognition of innovation is required by the business effectiveness, its implementation relies on legitimacy on the part of organizational agents as well as its achievement faces bureaucracy, resistance and blindness. The analysis here carried out was supported by empirical data surveyed through individuals whose creative projects were rebuked by the enterprises where they had worked. Without giving up their ideas they settled their own enterprises to carry out their projects thus putting into light the creative process grounded on resilience, personal causation and entrepreneurship.
\end{abstract}

In many of the fields of human life creativity has emerged more frequently as a relevant theme of study, due to the complexity of the solutions demanded in situations and environments characterized by uncertainty, absence of frameworks or paradigms and 
breakdown of others. In business and organizational sphere, that's exactly the ambience of present scenario, in which demand for innovation is prevalent as a competitive factor. Creativity comes up, then, as a requisite for innovation, differential element when facing challenges and problems of daily life and business.

Assumed as a human potential always present, when allied to entrepreneurial attitude and action, creativity is capable to contribute to innovation. The relationship between creativity and innovation is studied, focused on the genesis of innovative enterprises, because, even knowing the necessity of innovate, organizations have to deal permanently with the so called organizational ambidestry, characterized by simultaneity of maintenance and innovation of the business. Even recognizing that innovation is necessary to guarantee success of business, organizations and society, implementation of any innovative process depend upon facing agents of recognition, in charge of identifying and authorizing it as a way of doing and of making in a certain environment and, for that, the tradition of taylorist and bureaucratic models of management is, sometimes, cause of blindness. The "success threat" is one of the contingent factors of their refusal of creative proposals, potentially innovative. This factor relates to organizational culture and its flexibility and openness to the new. Present investigation was supported by empirical study, with subjects whose projects were refused by organizations to which they worked for who, then, decided to create own organizations, revealing not only resilience, but, especially, personal causality.

Key-words: creativity, innovation, entrepreneurship, resilience, personal causality. 


\section{La creatividad humana bajo las lentes del empreendedorismo innovador}

\section{Resumo}

Esta tesis estudia la creatividad dentro del contexto de la innovación en las organizaciones. La creatividad es una cuestión relevante en diversos campos de la vida humana, en razón de la complejidad de las soluciones exigidas en situaciones y contornos marcados por incertidumbres, ausencia o fracaso de modelos y de paradigmas. Ese entorno caracteriza el escenario actual adonde predomina la innovación como factor competitivo. La creatividad surge como fuerza motriz para las innovaciones, fundamento de su calidad y factor diferencial delante de los desafíos y problemas de los negocios. Entendida como potencialidad siempre presente en el ser humano, cuando en alianza con a la actitud y a la acción emprendedora, la creatividad es capaz de contribuir para la innovación. La relación entre creatividad y innovación es aquí estudiada bajo el foco de la génesis de los emprendimientos innovadores porque mientras se reconoce la necesidad de innovar, las organizaciones tienen que manejar la ambidestría que es la simultaneidad del mantenimiento y de la innovación en su negocio. Mismo reconociendo la necesidad de la innovación para el éxito del negocio, su implementación depende de la legitimación por parte de los agentes y su viabilización mismo dentro de contextos burocráticos, resistentes y ciegos. Este análisis fue apoyado en investigación empírica que estudio sujetos que tuvieron proyectos creativos recusados en las organizaciones adonde trabajaban y sin abandonar sus ideas crearan empresas propias, revelando en ese proceso, creatividad, resiliencia, emprendedorismo y causalidad personal.

Palabras clave: creatividad, innovación, emprendedorismo, resiliencia, causalidad personal. 


\section{Sumário}

Capítulo I: O capitalismo da inovação

1.1. O imperativo e os paradoxos da inovação 4

1.1.1. Uma questão complexa

1.1.2. O custo e o risco da inovação $\quad 8$

1.1.3. A velocidade da inovação 9

1.1.4. A abrangência da inovação 11

1.1.5. A gestão da inovação 12

1.2. A era da diferença e do diferencial competitivo 13

1.3. Criatividade, empreendedorismo e inovação 16

$\begin{array}{ll}\text { 1.3.1. A questão do reconhecimento } & 18\end{array}$

1.4. Motivação e realização humana $\quad 21$

1.5. Objeto e objetivo 24

1.6. Componentes deste estudo 26

Capítulo II: Criatividade, um conceito plural 29

2.1. A criatividade como questão teórica 30

2.1.1. Criação divina, criação humana: o livro do Gênesis 31

2.2. Platão e Aristóteles: objetivação ou transcendência? 34

2.3. Outra ordem de critérios: o conceito de criatividade como categoria de prática 38

2.3.1. A combinação de elementos $\quad 39$

2.4. Novas Gestalts: a dinâmica da subjetividade 43 
2.6. A dimensão estética 52

2.7. Abordagem psico-social do fenômeno criativo 55

2.7.1. A questão do valor: quanto vale uma idéia? 59

$\begin{array}{ll}\text { 2.7.2. Tipologias da criatividade } & 60\end{array}$

2.8. O que é a criatividade?

Capítulo III: A pessoa criativa

3.1. As grandes linhas teóricas da psicologia e a criatividade $\quad 71$

3.1. Personalidade criativa? $\quad 71$

3.2. Adaptadores (as) ou inovadores (as)? 75

3.3.1. Hector Fiorini: a saúde mental e a criatividade 79

3.3.2. Winnicott: o brincar e o criar $\quad 84$

3.3.3. Freud: inconsciente, associação livre, chiste, sublimação 86

3.3.4. Wilhelm Reich e o trabalho criativo. Alexander Lowen, o prazer e a

$\begin{array}{ll}\text { criatividade } & 88\end{array}$

3.4. A visão cognitivista: Piaget e a inteligência reflexiva 90

3.5. A psicologia humanista e a elaboração individual 93

3.6. De Guilford a Amabile: os alicerces teóricos de um campo de conhecimento numa

$\begin{array}{ll}\text { perspectiva histórica } & 98\end{array}$

3.7. Motivação intrínseca ou causalidade pessoal? 108

3.8. A psicologia da criatividade 112

Capítulo IV: A necessidade de diferenciação dos conceitos 117 
4.1. Criatividade, inteligência e sabedoria

4.2. Entre a criatividade e a inovação: o mercado

4.2.1. Diferenças entre criatividade e inovação

4.3. A tensão entre criação e mercado

4.4. Invenção e descoberta

4.5. Invenção e inovação

4.6. Originalidade e autoralidade da criação: a problemática da avaliação e aceitação do novo pelo ambiente social

4.7. Propriedade intelectual e patentes

4.8. O problema do plágio e sua relação com a criatividade

4.9. Criatividade, inovação e empreendedorismo

4.10. Empreendedorismo inovador: paixão e emancipação humana

4.11. Criatividade e conceitos correlatos

5.1.3. Economia criativa e indústrias criativas

5.1.4. Racionalidade versus criatividade 
5.2.4. A cultura organizacional e o efeito Einstellung

5.2.5. Ambidestria organizacional: investigação do novo e utilização do consagrado 189

5.3. Criatividade e empreendedorismo

5.3.2. Incubação de empresas

\section{Capítulo VI: Do intraempreendedorismo criativo ao empreendedorismo inovador}


Capítulo I 


\section{O capitalismo da inovação}

“O talento e a criatividade são o petróleo do futuro” (Francis Ford Coppola).

Leonardo da Vinci desenhou o helicóptero e o submarino, dentre as inúmeras invenções oriundas de seu gênio criativo, mas nenhum desses meios de transporte, tão comuns e valorizados no século $\mathrm{XX}$, poderia ter-se convertido em inovação com a tecnologia e os materiais disponíveis no século XVI. Por esse motivo, a inventividade de Leonardo não sensibilizou a sociedade e economia da época (Drucker, 1985).

Fatos como esses ensinam muito sobre invenções e inovações, pois, embora o arsenal tecnológico atual possibilite viabilizar muitas idéias como as de Leonardo, certamente algumas idéias criativas do mundo atual podem estar sendo igualmente ignoradas. A sociedade atual, diferentemente daquela em que viveu Leonardo da Vinci, estimula, viabiliza e depende de inovações e invenções. A dinâmica de sua economia e a velocidade do avanço tecnológico requer idéias criativas que possam ser transformadas em inovações pela via do empreendedorismo, mas essa dependência expõe o conjunto de contingências históricas, culturais e econômicas atinentes ao reconhecimento das mesmas. Assim, mesmo com as demandas sociais e econômicas atuais por idéias criativas que possam ser transformadas em inovações, propostas inovadoras economicamente viáveis têm sido recusadas, revelando que a relação entre empreendedorismo e inovação é mais complexa do que parece.

Esse campo multidisciplinar é o território de estudo desta tese. Pergunta-se porque, em um momento de tão alta competitividade, avanço tecnológico e disponibilidade de capital, 
tantos (as) inventores (as) e inovadores (as) enfrentam dificuldades e obstáculos para viabilizar e empreender suas idéias. Esta questão abrangente é o eixo norteador desta tese, na qual se pretende contribuir para a compreensão do ato criativo e sua viabilização.

O presente capítulo, introdutório, é dedicado à apresentação desse território de estudos, integrando alguns aspectos do cenário atual das organizações, as mudanças do trabalho humano nesse contexto e o incremento do empreendedorismo no Brasil e no mundo, bem como a problemática do reconhecimento, elemento moderador da cadeia de eventos situada entre a criação e a viabilização de idéias e projetos inovadores. Elaborações criativas em vários campos de atividade são também comentadas como pano de fundo da inovação no universo da vida social e produtiva. 
Há não mais de cem anos nem o óleo vegetal jorrando do solo nem a bauxita-minério de alumínio - constituíam recursos. Eram apenas coisas que tornavam o solo improdutivo. $O$ fungo da penicilina era uma praga, não um recurso e, portanto, os bacteriologistas faziam todo o possível para proteger as culturas de bactérias da contaminação pelo fungo. Até que, nos anos 1920, Alexander Fleming, médico londrino, percebeu que esta "praga” era o assassino de bactérias que os bacteriologistas vinham procurando e, a partir de então, o fungo da penicilina tornou-se recurso de valor (Drucker, 1985).

\subsection{O imperativo e os paradoxos da inovação}

A profunda transformação econômica e social das últimas décadas traz consigo a demanda acelerada pela inovação e seus impactos visíveis na adaptação das empresas e instituições a novas contingências internas e externas.

No contexto atual, inovar não é uma opção, mas um imperativo da competitividade. Os mercados não só têm absorvido bem muitas inovações, como até mesmo buscam novidades e as empresas já não esperam a inovação chegar até elas, mas investem para ser pioneiras como meio de diferenciação de sua marca. Se quiserem ser competitivas, elas mesmas são obrigadas a produzir o novo. Inovar é um processo que atinge produtos, processos e serviços de todos os tipos e categorias. "Inovar ou morrer" é um lema que vem se tornando um imperativo (Plonski, 2006). Nas palavras de Drucker (1985, p. 208): “A empresa que não inova inevitavelmente envelhece e declina”. 
A competitividade tem demandado diferenciação dos concorrentes e as inovações, ainda que incrementais, têm sido o caminho para esse rumo. Essa tendência não se limita a um modismo, mas oferece dezenas de sinais de que se vive uma nova etapa da era industrial, uma fase da evolução do sistema capitalista em que a propriedade dos negócios e a riqueza decorrente da produção de bens e serviços não são suficientes para garantir os resultados financeiros, pois a velocidade de transformação da vida produtiva expulsa as empresas e organizações que não inovam para competir em mercados cada vez mais exigentes (Malvezzi, 2008, mimeo).

Esta equação revela que os produtos e serviços apresentam a potencialidade de serem inovados. Segundo Tarde (2007), a inovação tem origem na potencialidade dos eventos de ser diferente daquilo que são. A exploração dessa potencialidade é denominada processo de inovação e tem sido uma das atividades da gerência em todas as empresas que buscam ser competitivas. Se, desde o final do século XIX, a gestão dos negócios (produção de massa) depende do apoio da ação racional, na atualidade, pode-se afirmar que ela depende igualmente da inovação. Assim, a convivência entre racionalidade e inovação tem sido um dos desafios dos gestores (as) e pesquisadores (as).

\subsubsection{Uma questão complexa}

O estudo da inovação tem merecido freqüentes debates na literatura (Prahalad, 2005; Hamel, 2006) pela sua complexidade, pelo impacto na cultura organizacional, pelo custo, pela demanda de competências, por suas fronteiras com outras questões e por seu caráter estratégico. A inovação é uma questão complexa até mesmo pela dificuldade encontrada em sua conceituação e seus critérios. Até que ponto um modo diferente de se realizar 
uma tarefa merece a alcunha de inovação? Assume-se como inovação qualquer aperfeiçoamento em algum dispositivo ou serviço ou somente aquelas melhorias que trazem efeitos significativos? As velhas questões da sociologia sobre critério de mudança (Burrell \& Morgan, 1979) se concentram na compreensão desse conceito. Frente a isso, a propaganda tem sido uma má conselheira porque denomina a tudo de inovação como esta fosse uma alteração sem critério algum.

Fala-se frequentemente, não apenas no capitalismo, mas na cultura da inovação (Gargioni et al., 2005; Shyniashiki, 2004). E não apenas nos negócios, mas também nas empresas que os abrigam e os promovem criou-se uma subjetividade relacionada à inovação, como se inovar fosse preciso em todos os aspectos da vida social e econômica. Em função dessa cultura, valoriza-se o novo, sem se aprofundar se, de fato, é melhor ou compensa mais do que o antigo, pois pode ocorrer, por exemplo, que a compensação financeira venha acompanhada de interesses contrários à sociedade ou à preservação do meio ambiente como no caso do DDT, mencionado mais adiante.

Alguns setores da economia, como a indústria da moda, dependem e reproduzem essa cultura. Inúmeras propagandas são vistas tentando convencer o cliente a mudar por algo que lhe é apresentado como novo, ou seja, como algo que o servirá melhor do que o objeto ou serviço anterior. Entendida dessa forma, a inovação é "a arte da transição" (Hirsch, 1972) porque altera o mundo adaptando-o a novas contingências. Pode-se dizer, de maneira simples, inovar é a habilidade de reformular algo de sua condição (ou forma) original para torná-lo apropriado, seu valor enriquecido e seu status de qualidade mais elevado, para alguma finalidade. 
Esse conceito é compatível com aquele proposto por Drucker (1985) para o empreendedorismo, a saber, a "transferência de recursos de áreas de baixa produtividade e rendimento [para adentrar] áreas de produtividade e rendimentos mais elevados" (Drucker, 1985, p. 37). Revelam-se, pois, algumas das relações entre criatividade, inovação e empreendedorismo, sendo a criatividade a via para identificar um recurso onde antes havia matéria ou natureza e o empreendedorismo, a possibilidade do recurso criado adentrar áreas mais elevadas de produtividade, o que caracterizaria a inovação.

Para a gestão das organizações, a inovação traz um paradoxo: estimulam-se os indivíduos a inovar e, quando isto ocorre, elas [organizações] podem se ver obrigadas a mudar muitos aspectos, como a equipe, os custos, as prioridades, os produtos e, não raramente, até mesmo sua estratégia, sendo a não implementação dos projetos fonte de frustração e desalento nos indivíduos envolvidos.

Os obstáculos ao empreendimento e à inovação são reais, significando a saúde de uma organização ou algum tipo de doença degenerativa, tais como burocracia, formalidade ou complacência. "Se o espírito empreendedor e a inovação não vicejam numa organização, alguma coisa deve estar sufocando-as". "A organização deve ser receptiva à inovação e predisposta a ver a mudança como oportunidade e não como ameaça" (Drucker, 1985, p. 209), mas a flexibilidade necessária para essa predisposição nem sempre é encontrada no universo organizacional, mesmo naquelas organizações que têm a inovação como princípio estratégico.

As organizações carregam o peso de mais de cinqüenta anos de convívio com a teoria da administração científica proposta por Taylor (1948), ou seja, ainda prevalece o modelo em 
que o controle, a busca de evitar o erro e o conflito e a quase ausência do fator estético são valores e características marcantes, seja da gestão, seja na cultura organizacional. A explicação desse fenômeno pode estar no efeito Einstellung, discutido no capítulo 5 deste estudo, referente à armadilha do sucesso nas organizações, à valorização daquilo que deu certo no passado ou à própria cultura organizacional que, muitas vezes, atua como uma força contrária à inovação no contexto das organizações. Por isso, a compreensão da inovação nos negócios torna-se mais realista se for entendida como um processo, uma vez que cada mudança gera outras mudanças.

\subsubsection{O custo e o risco da inovação}

Inovar tem custo e demanda investimentos. Frequentemente, a inovação implica pesquisa, contratação de especialistas, alterações de instalações, preparação de pessoas e mudança de critérios de avaliação. Muitas empresas que cuidam de negócios volumosos têm previsto, em seus orçamentos, investimentos em inovação. Os riscos envolvidos nesses investimentos são altos porque implicam em se acompanhar uma tendência para se evitar a produção de algo que terá vida curta ou que não compensará pela baixa atratividade ou mesmo pela estratégia comercial do concorrente. O acompanhamento permanente de tendências, por sua vez, demanda que uma organização esteja constantemente em contato com a realidade externa a ela, não se isolando do que a cerca, uma vez que, na dinâmica da inovação é possível que outras empresas que participam deste mesmo processo, inovem antes, implicando perda de grandes quantias de dinheiro em risco e é bom lembrar que uma abertura contínua para o ambiente circundante à organização tampouco faz parte da “cartilha” proposta por Taylor (1948). 
Nas palavras de Drucker (1985), uma a cada cem patentes produz receita suficiente para repor os custos de desenvolvimento e as taxas da própria patente. Além disso, não se sabe ao certo quais idéias têm chance de ser bem sucedidas. $\mathrm{O}$ próprio autor se pergunta: porque o aerosol foi bem sucedido? E porque o zíper tem aceitação e praticamente substitui os botões embora tenda a emperrar? (Drucker, 1985). Tais perguntas remetem ao fato de que a dedicação à inovação implica em competências específicas para seu desenvolvimento e justifica que muitas empresas pedem a criatividade como critério de seleção ou a colocam como meta em programas de treinamento, imaginando que inovação e criatividade guardam estreita relação e são habilidades que podem ser desenvolvidas.

\subsubsection{A velocidade da inovação}

A velocidade de penetração das inovações, especialmente de natureza tecnológica, na vida cotidiana, é fato incontestável. Em menos de cem anos, operou-se uma profunda transformação na escrita de textos, passando da escrita à mão para das máquinas de escrever - mecânicas, elétricas e programadas - e destas, aos processadores. Neste percurso, novas funcionalidades produziram alterações em toda a teia social, fazendo com que algumas profissões tendessem à extinção, como os (as) datilógrafos (as) e, simultaneamente, redefinindo parâmetros de ensino, aprendizagem e qualificação dos (as) profissionais de acordo com a atualização (ou não) frente às inovações introduzidas. No domínio da informática, a tendência é que, rapidamente, uma versão de programa (software) venha a atualizar a anterior, passando os (as) usuários (as) a depender da versão mais moderna para efetuar as operações com as quais estavam familiarizados (as). As atualizações periódicas demandam, por vezes, configurações distintas das máquinas, 
criando um ciclo infindável de mudanças, confirmando a inovação como a arte da transição.

O aumento da velocidade das inovações pode ser constatado também a partir do tempo necessário para que determinado produto ou funcionalidade seja incorporado socialmente, tornando-se corriqueiro no cotidiano. Se a televisão em branco e preto levou cerca de vinte anos para este resultado, a televisão colorida demorou menos de dez anos para atingi-lo e o aparelho de videocassete, cerca de oito anos. Para o computador pessoal, foram necessários apenas cinco anos e para a telefonia celular, cerca de três anos (Vasconcellos, 2008). A literatura desta área entende que "é necessária a aceitação de pelo menos $15 \%$ de uma dada população antes que a idéia possa ser considerada mainstream" (Neilson, 2008, mimeo) e a história da inovação, das invenções e descobertas indica que o tempo necessário para a introdução de elementos tidos hoje como corriqueiros ou imprescindíveis, tais como a penicilina, o transistor ou o nylon, foi muito superior à dos produtos mencionados acima.

É fato também que a velocidade de desenvolvimento de novas tecnologias traz consigo a alteração do ciclo de vida, das funcionalidades e do uso dos produtos, fenômeno observável na indústria automobilística, por exemplo, em que o número de lançamentos de novos modelos que cada fabricante realiza a cada ano tem crescido, se comparado às décadas passadas (Vasconcellos, 2008). Também o aparelho de fax exemplifica este fenômeno, à medida que sua função incorpora-se aos softwares dos computadores, tornando supérfluo o aparelho em si. Todas essas questões já haviam sido abordadas por Baudrillard (1981) em sua análise da sociedade de consumo, mas os fenômenos têm se intensificado sobremaneira na fase atual do sistema capitalista. 


\subsubsection{A abrangência da inovação}

A inovação não se restringe aos produtos ou funcionalidades voltadas ao universo do consumo, nem se limita a coisas tangíveis. "Inovação é um termo econômico ou social, mais que técnico" (Drucker, 1985, p. 43). Inovações sociais, introduzidas mundialmente na década passada, alocaram assentos preferenciais no transporte coletivo e possibilitaram que fossem instalados telefones públicos diferenciados para pessoas com deficiências. Nielson (2008) explica que tais inovações tiveram início com as reivindicações de igualdade de direitos derivadas do retorno de soldados americanos mutilados aos Estados Unidos da América após a Guerra do Vietnã e posteriormente, se estenderam a outros indivíduos com diversos tipos de deficiência. Recentemente, também os idosos (as) têm se beneficiado com políticas públicas em muitos países que, no caso brasileiro, proporcionaram acessos rebaixados em ônibus urbanos e fila preferencial em bancos, além de assentos preferenciais no transporte coletivo. Todas estas inovações seriam difíceis de antever há um século atrás e seriam impensáveis em outros momentos históricos, possibilitando concluir que a velocidade da absorção do novo na sociedade capitalista pósindustrial é pervasiva a todos os campos da vida e não somente às organizações produtivas.

Drucker exemplifica que inovações não se restringem aos aspectos econômicos a partir da transformação sofrida pela universidade americana ao longo do século XX. Estudantes viajando diariamente para a universidade ao invés da condição anterior que incluía moradia nos campi universitários com dedicação plena aos estudos, cinco dias por semana, das nove às cinco foi a resposta a uma importante mudança de rumo no mercado, no 
prestígio do diploma universitário, passando da "classe alta" à "classe média", alterando a importância de ter um curso superior. Para o autor, também o hospital, como inovação social, teve maior impacto na assistência médica que muitos avanços da medicina, bem como a compra a prazo que possibilitou a fazendeiros, no século passado, a aquisição de máquinas agrícolas (Drucker, 1985).

\subsubsection{A gestão da inovação}

Velocidade, abrangência, risco, custo, todos esses são aspectos gerenciais da inovação. Tanto nas inovações sociais quanto nas tecnológicas e organizacionais fica claro que não basta a introdução de uma lei ou a determinação de uma gerência. A implantação de assentos preferenciais no transporte coletivo não se resolveu com a promulgação da lei e com a fabricação de novos veículos ou adaptação desses assentos. Campanhas educacionais com foco no respeito ao direito alheio têm sido necessárias para que o processo se complete e a população adquira o hábito de respeitá-lo.

É importante ressaltar que, em geral, a inovação, para ser aceita, deve ser contraposta ao modo prevalente até então e, desta forma, comprovar que sua substituição pode ser vantajosa em algum nível para um grupo, comunidade ou para a sociedade como um todo. Este processo envolve diversos fenômenos e mecanismos que serão aprofundados nesta tese. Os exemplos são inúmeros, mas importa citar dois casos mundialmente conhecidos: o primeiro deles foi a introdução do leite em pó, na década de 1950, que veio acompanhada de uma campanha de marketing que desqualificava o aleitamento materno, o que fez com que, na época, muitas mães deixassem de amamentar bebês, acreditando na "praticidade" do novo processo, não vendo os prejuízos graves para o sistema imunológico dos bebês. O 
segundo exemplo, de conotação mais positiva, refere-se à introdução da triagem prenatal, o popularmente denominado "teste do pezinho", introduzido nas maternidades brasileiras por força da lei federal (que o tornou obrigatório) a partir de 1992, visando à prevenção de doenças como fenilcetonúria e hipertireodismo congênito. Sua introdução enfrentou resistências de natureza diferente, uma vez que ele não teve que "competir" com outros testes ou outras práticas diagnósticas existentes até então. $\mathrm{O}$ teste tem enfrentado alguns receios de mães e pais sobre a logística de entrega dos mesmos, mas tem sido bem aceito pela maioria da população.

Inovar é, portanto, diferenciar-se, mostrando vantagens em relação ao que prevaleceu até então. O processo de diferenciação é a criação do novo.

\subsection{A era da diferença e do diferencial competitivo}

Conforme mencionado anteriormente, o cenário empresarial atual enfatiza a necessidade de estabelecer um diferencial competitivo, prescrevendo o diferente, o não igual e a nãorepetição como parâmetros para a sobrevivência das organizações em relação aos competidores. Fica implícita a participação da criatividade neste processo, em função da conceituação desta como "instituição da alteridade" (Bartoli, 2008), do que é o outro, o não idêntico ${ }^{1}$. Para a construção de um diferencial, é mister considerar as potencialidades que se pode explorar em relação ao outro e, se definida a criatividade como a combinação de certos elementos de forma peculiar, singular, resultando numa síntese única, distintiva de outras, certamente ela será essencial para a singularização de uma organização no cenário competitivo atual. Identidade e alteridade, como se verá no capítulo II, se mesclam na discussão do conceito do que é criativo.

\footnotetext{
${ }^{1}$ O capítulo II apresenta a visão de Bártoli (2008), dentre outros.
} 
Diferenciar-se tem valor ou agrega valor ao que é feito ou produzido. O diferencial não é só necessário para as organizações, mas impacta e é fator crítico de sucesso de profissionais em mercados de trabalho competitivos, demandando uma busca constante de atualização de si mesmos para a sobrevivência nesse ambiente. Os casos estudados, objeto do capítulo VI, revelam algumas facetas desta questão.

$\mathrm{Na}$ era atual, o design emerge como uma ferramenta para a criação deste diferencial. Termo da língua inglesa que se refere a um determinado esforço criativo, segundo o qual se projetam objetos ou meios de comunicação diversos para o uso humano, pode ser entendido simultaneamente como uma área do conhecimento humano e uma arte ou ciência aplicada. Contém uma parte subjetiva e outra objetiva, sendo esta ligada à consciência à ciência e a parte subjetiva, à imaginação e criatividade.

Costuma-se traçar as origens do design moderno junto ao apogeu da Era Industrial a partir da emergência de novos profissionais que, apesar de não executarem os produtos, projetavam-nos. Um marco na história do design moderno ocorre com as experiências da escola alemã Bauhaus (1919-1933), que se tornou a base para o ensino do design e arquitetura no século XX. Design é um dos elementos que contribuem para a diluição das fronteiras entre o universo artístico e produtivo / empresarial fazendo com que a demanda por resultados se coloque para além da eficácia convencional e inclua a dimensão do belo e do sensível. A partir do design, a criatividade emerge pela via da bissociação (Koestler, 1964) entre as matrizes do sensível e do prático, do belo e do útil. Importante frisar que, ao introduzir fatores que vão além da eficiência, o design impõe mudanças no modelo taylorista dominante nas organizações que os desconsiderava. 
No mundo moderno, o design se estabelece dentro das organizações como o processo criativo institucionalizado. Embora nem todas as empresas disponham de áreas específicas que lidem com o design, os negócios dependem cada vez mais dele para a criação do diferencial competitivo. Há empresas que se utilizam de uma ferramenta denominada "think tanq" para geração de idéias e resolução de problemas, não como área institucionalizada. Trata-se de espaços criados para esta finalidade que transcendem os organogramas formais das organizações, fato que tem se mostrado como tendência alternativa às áreas tradicionais de pesquisa e desenvolvimento. O design de brinquedos da empresa Fischer - Price, por exemplo, quando do lançamento do brinquedo Smart Cycle, teve que superar preconceitos dos pais e das crianças com relação ao formato do objeto, desenhar uma forma neutra em termos de gênero (feminino e masculino) para satisfazer crianças de ambos os sexos e agradar pais e mães com filhos e filhas, e enfrentar inúmeros outros problemas (Kelley, 2008); para este desenvolvimento, foram utilizadas técnicas de incentivo à criatividade. Este caso, apresentado durante um congresso internacional sobre criatividade e inovação em 2008, ilustra o desenvolvimento criativo de um produto envolvendo técnicos (as) e profissionais de distintas áreas da empresa que não se limitou à área de pesquisa e desenvolvimento da mesma.

O design é, simultaneamente, instrumento de inovação e processo criativo, revelando como os dois temas se mesclam e se interpenetram quando estudados no contexto das organizações.

\subsection{Criatividade, empreendedorismo e inovação}


Como duas velas que, acesas juntas, não mais permitem a individualização de cada chama, também a criatividade e a inovação apresentam níveis de sobreposição que torna difícil separá-las e reconhecê-las individualmente. De maneira análoga à gramática da língua portuguesa, a criatividade pode ser associada a um verbo intransitivo, processo completo em si mesmo, ao passo que a inovação é análoga a um verbo transitivo, demandando pronomes ou advérbios para se completar. Nesta analogia, a atitude empreendedora corresponderia a uma terceira vela, àquilo que completa o verbo inovar. Autores como Drucker (1985) entendem que “inovação é o instrumento específico dos empreendedores, o meio pelo qual eles exploram a mudança como uma oportunidade para um negócio ou serviço diferente" (p. 25).

O estudo da inovação tem inúmeros pontos de contato com a análise da criatividade. Embora reconhecidas como questões intimamente relacionadas, não se sabe bem como e por que ambas se justapõem e se diferenciam, ao mesmo tempo, e o quanto uma participa da outra, ou o quanto uma concorre com a outra. Se for considerada a conceituação de Shapiro (2001), que entende que o ethos artístico demanda do (a) artista se empenhar na perfeição interna de sua obra, independentemente do sufrágio que o público dedicará àquela, a inovação nos negócios oferece uma diferença a partir da criatividade, uma vez que, do ponto de vista dos negócios, a prioridade não tem sido a perfeição interna, mas sua aceitação por parte do público. A inovação, portanto, constitui um dos contextos possíveis para a criatividade, agregando a ela a problemática do reconhecimento, uma vez que algo pode ser criativo num dado país e não noutro, em dado momento histórico, mas não em outro e a contextualização do que é criativo impacta sobremaneira a inovação. 
Dizem alguns autores que "A criatividade é uma condição necessária, mas não suficiente para a inovação" (Vehar, 2008), uma vez que, na inovação está implicada uma relação com uma determinada realidade social [econômica, comercial] e a aceitação da inovação pela sociedade ou comunidade em que ela está inserida; trata-se de um processo que só termina com a introdução desta no mercado ou, segundo outros autores, pela criação de uma nova realidade social, econômica ou comercial (Smulders, 2008, citado por Vehar, 2008). Em outras palavras, a criatividade não tem o poder, por si só, de fertilizar sua instrumentalidade e, para que se transforme em inovação, depende da atitude empreendedora para fazê-lo e também demanda a avaliação externa de seus efeitos, como na analogia do verbo transitivo.

\subsubsection{A questão do reconhecimento}

Um conceito correlato tanto à inovação como à criatividade é o do reconhecimento. Em cada um dos campos em que a criação ou a inovação estiver inserida, haverá agentes do reconhecimento que podem ser críticos (cinema, literatura, dentre outros), órgãos governamentais (inovações institucionais ou políticas) ou pares (trabalhos acadêmicos, por exemplo). Estes se verão imbuídos do poder de avaliar seja a originalidade da criação, seja a viabilidade da inovação e neste processo estará envolvida a inserção numa escala de valores, a ser discutida no capítulo II. Assim, a subjetividade humana se faz presente como fator essencial no processo de inovação.

Inúmeras premiações foram instituídas ao longo do último século com a finalidade de tornar público este processo de reconhecimento bem como, na maior parte dos casos, seus critérios. O Prêmio Nobel, nas categorias de literatura, economia, paz e ciências básicas, é 
um deles. Na música popular, destaca-se o Grammy e no cinema, o "Oscar". No campo do empreendedorismo inovador, vale ressaltar a importância do Prêmio ANPROTEC e também o prêmio FINEP $^{2}$ de Inovação. Em qualquer um deles, o processo de reconhecimento estará sempre sujeito a preconceitos, estereótipos e vieses cognitivos de vários matizes que podem comprometer projetos de qualidade (Barlach, 2008).

Como se disse anteriormente, a questão é complexa, pois pode suceder, como no caso de certos produtos, que estes sejam inovadores e eficazes no curto prazo e revelem-se nefastos no longo prazo. É o caso do DDT (diclorodifeniltricloroetano), inseticida largamente empregado no combate a mosquitos transmissores de doenças, como a malária, e de pragas da monocultura. O caso foi um dos precursores da Revolução Verde dos anos 1970, ao questionar fortemente o impacto da tecnologia na saúde humana e ambiental. Os efeitos cumulativos do DDT — no organismo e meio ambiente — só aparecem no longo prazo. Na década de 1960, problemas também ocorreram na indústria farmacêutica com os inúmeros casos de deformações constatadas em fetos e recém-nascidos, consequiência do uso indiscriminado da talidomida, usada até então como sedativo e hipnótico (Barata, 2009).

Da singularidade da criação à pluralidade - ou multiplicidade - da inovação, há inúmeros passos a empreender, no sentido de viabilizar aquilo que foi potencializado pela criação. Como mencionado anteriormente, se a criatividade pode ser vista como um processo relativamente autônomo, a inovação estará sempre inserida num contexto histórico, encarregado de compará-la ao que existia anteriormente ou ainda promover a recriação frente a algo que foi superado. A autonomia da criação com relação ao processo histórico

\footnotetext{
${ }^{2}$ FINEP - Financiadora de Estudos e Projetos. Empresa governamental brasileira com a missão de fomentar a inovação e a pesquisa científica e tecnológica.
} 
pode ser comprovada em inúmeras histórias de compositores, artistas plásticos e cientistas que só obtiveram reconhecimento pós-mortem (Carpeaux, 1958; Neilson, 2008) ou na referência que faz Drucker (1985) a Leonardo da Vinci que desenhou o helicóptero e o submarino, dentre outros, mas não teve qualquer de suas invenções convertida em inovação em função da tecnologia e dos materiais existentes em sua época, ou seja, suas invenções não puderam alcançar receptividade na sociedade ou economia de seu tempo.

Assume-se aqui que a criatividade refere-se aos produtos únicos, singulares, sejam eles idéias, invenções, processos ou soluções de problemas, ao passo que a inovação diz respeito à inserção dessas criações no mercado e, nesse sentido, seriam processos análogos à produção de singularities (criatividade) ou de commodities (inovações) (Busch, 2000; Lash, 2007).

Se a inovação é o processo pelo qual os (as) empreendedores (as) convertem oportunidades em idéias vendáveis ou comercializáveis (marketable), “a inovação é a função específica do [a] empreendedor [a]... é o meio pelo qual ele [ela] cria novos recursos produtivos de riqueza ou dota os recursos existentes de potencial aumentado para criar riqueza" (Drucker, 1985, In: Couger et al., 1995, p.374). Assim, a diferenciação entre criatividade e inovação não seria completa sem o terceiro fator que pertence ao tripé, a saber, o empreendedorismo.

Uma das hipóteses desta tese é que a inovação demanda a presença de dois vetores, a saber, a criatividade - o novo e o original - e o empreendedorismo, ou seja, sua viabilização. Se a criatividade humana for entendida como geradora de valor de uso e a inovação for associada ao valor de troca (Marx, [1867], 1980), a transição de uma a outra 
dependerá da implementação da idéia ou processo em determinado contexto, para a qual será necessária a atitude empreendedora. Embora o vetor criativo tenha em comum com a inovação a sujeição ao reconhecimento, ele pode ser identificado, mas não possuir valor de troca, ao passo que a inovação sempre terá este valor. Obras importantes da história da música foram legitimadas, mas não alcançaram sucesso comercial, como ocorreu com Carmem, de Bizet. A análise dessas questões demanda um caminho integrador que abarca conceitos correlatos, tais como invenção e descoberta, que se interpenetram e o reconhecimento, que faz a ponte entre as duas.

\subsection{Motivação e realização humana}

Subjacente tanto à criatividade quanto à inovação, está a condição humana da autorealização. Motor do empreendedorismo e componente da inovação, será objeto de estudo mais aprofundado nos capítulo III e V. Aqui o assunto é introduzido.

Abraham Maslow é um estudioso clássico da motivação humana que cunhou o termo "criatividade auto-realizadora", referindo-se ao potencial humano para a criação e para a auto-realização que, uma vez presentes, corporificariam a saúde mental, a vida produtiva e a flexibilidade no modo de viver ${ }^{3}$. Individuação, realização de potenciais, realização de missão (vocação ou destino), conhecimento mais completo e aceitação da própria natureza, todos estes são elementos que caracterizariam a mais elevada motivação humana, a criatividade auto-realizadora, para Maslow. Para ele, pessoas que realizam o potencial criativo podem não ser brilhantes em uma área específica nem necessitam sê-lo, pois o que importa neste processo é "tornar-se aquilo que se é capaz de ser", em graus

\footnotetext{
${ }^{3}$ A associação da criatividade à saúde mental e não à doença indica uma transformação na visão dominante até então, fundada em Platão, para quem a pessoa que cria estaria dominada por forças sobrenaturais (mesmo que divinas) e, assim, distante de sua consciência e próxima da insanidade.
} 
crescentes de integração e sinergia interna, pela unificação de aspectos isolados ou mesmo opostos da personalidade e da realidade (Maslow, 1971), pois a base da auto-realização é a motivação para o crescimento e não o medo ou a falta.

Em seus estudos, Maslow identificou características específicas dos indivíduos criativos, mentalmente saudáveis e auto-realizados. Tais indivíduos tendem a não necessitar ou procurar fama, aplauso, popularidade, status, prestígio ou mesmo enormes quantias de dinheiro (Maslow, 1971; Neilson, 2008, manuscrito); tendem, também, a não temer e, por vezes, a serem atraídos, pelo mistério, pelos problemas não resolvidos, pelo desconhecido e pelo desafio.

Ao comparar a abordagem de Maslow às proposições de McClelland (1961), que estudou o comportamento empreendedor, é possível identificar inúmeros aspectos convergentes. Os estudos de David McClelland associam a necessidade de realização - base do comportamento criativo em Maslow - ao comportamento empreendedor e indicam que são características das pessoas motivadas para a realização: a) a capacidade de estabelecer objetivos altos, mas alcançáveis; b) a preocupação com a realização pessoal ao invés de recompensas - extrínsecas - pelo sucesso e c) o desejo de receber feedback relevante sobre o trabalho (como estou me saindo?), ao invés de feedback atitudinal (quanto você gosta de mim?). McClelland aponta ainda alguns traços da personalidade empreendedora, tais como: a) correr risco (moderadamente); b) ser desviante (com relação aos padrões sociais convencionais); c) ter alta necessidade de realização; d) possuir lócus de controle interno; e) ser tolerante à ambigüidade e f) apresentar extremos de competitividade, agressividade, impaciência, luta pela realização e a sensação permanente de estar sob pressão. Para ele, 
este é um conjunto de características psico-sociais que explicariam a preferência de alguns indivíduos por um "estilo de vida sem patrão" (McClelland, 1961).

As propostas de Abraham Maslow e David McClelland são fundamentais para a construção de um referencial teórico que permita a análise das manifestações criativas no empreendedorismo inovador, objeto desta tese. Ao associar a criatividade à necessidade de auto-realização, inclui-se a criação como uma força na dinâmica da personalidade e evidencia-se que, embora o impulso criativo esteja presente, isso não significa que o indivíduo seja capaz de transformá-lo em algo concreto, dependendo da atitude empreendedora para fazê-lo. O impulso criativo, por si só, não significa a capacidade de auto-realização, mencionada por Maslow. É necessário que o indivíduo identifique uma oportunidade e possa viabilizar um projeto a partir dela ou que se apresente um limite e, neste último caso, o indivíduo seja capaz de transformá-lo.

Confirmando a visão de McClelland et al. (1953), Rindova et al. (2009) afirmam que o ímpeto empreendedor revela o desejo de ficar livre da autoridade e quebrar com as restrições percebidas. Não se trata somente de perseguir oportunidades, mas de superar ou remover obstáculos, restrições percebidas no ambiente dos atores. O empreendedorismo é visto "como processo emancipatório com potencial de mudança mais amplo" (p. 477). Esses aspectos emancipatórios do empreendedorismo estão ligados aos sonhos e esforços para criar mudanças no mundo. Da mesma forma, De Charms (1968), que será estudado em mais detalhes no capítulo III desta tese, contribui para a compreensão do empreendedorismo a partir do conceito de causalidade pessoal, assim definido: “Causalidade pessoal é a iniciação, por um indivíduo, de um comportamento com a intenção de produzir uma mudança no seu ambiente" (p.6). 
Também no sentido de enfatizar a importância do elemento humano no processo de empreender, Cardon et al. (2009) buscam entender como a paixão poderia explicar comportamentos empreendedores que desafiam a visão racional, tais como correr riscos de forma não convencional, foco de intensidade incomum e crença em seu sonho. A paixão empreendedora é definida como um sentimento positivo intenso, acessível conscientemente, resultante do engajamento em atividades com sentido de identidade e saliência para o empreendedor. A paixão promove estados intensos de fluir e total absorção em suas atividades, fazendo com que as pessoas invistam tempo e energia, manifestem entusiasmo, zelo e intensa duração da sua atenção. Atividades são intensamente significativas, os objetos são reais, desejáveis e passíveis de memória, podendo ser imaginados e antecipados (Cardon et al., 2009, p. 512).

As profundas transformações pelas quais têm passado o trabalho humano nas organizações, assim como as mudanças nas próprias organizações, justificam a atualidade deste estudo, uma vez que este "estilo de vida sem patrão" descrito por McClelland tornase, muitas vezes, um parâmetro de busca para aqueles indivíduos que almejam a autorealização criativa, não a encontrando nos ambientes organizacionais convencionais. Este será um dos focos da análise aqui proposta, empreendida por meio do estudo de casos de pessoas que "criaram" empresas próprias a partir do reconhecimento da impossibilidade de realização pessoal e profissional dentro das organizações com as quais estiveram em relação. Essas pessoas estabeleceram empresas inovadoras a partir de uma atitude empreendedora que, a princípio, foi interna às organizações para, depois, transformar-se em empreendedorismo na acepção mais conhecida do termo. 


\subsection{Objeto e objetivo}

As questões que suscitaram esta tese referem-se à natureza e às características da criatividade no ambiente organizacional, no contexto da necessidade de inovação como diferencial competitivo. Especificamente, discute-se se a ambidestria organizacional - a necessidade de inovar e, simultaneamente, de manter aquilo que já se mostrou satisfatório ou bem sucedido (Soosay \& Hyland, 2008) é o fator causal que poderia explicar a criação de novas empresas por indivíduos que exerceram ativamente o papel intraempreendedor nas organizações em que estiveram inseridos. Em outras palavras, embora a pressão pela inovação seja um imperativo para a competitividade e sobrevivência dos negócios na atualidade, a dificuldade de gerenciar com ambidestria poderia expulsar indivíduos altamente criativos das organizações e estes, como manifestação da sua resiliência, criariam empresas, transcendendo a adversidade de ter suas propostas ou projetos negados pela organização, revelando não só a força da causalidade pessoal, mas contribuindo de outra maneira - uma maneira criativa - para a inovação a partir da proposição de novos empreendimentos. A criação de empreendimentos inovadores seria, então, a resposta resiliente de indivíduos criativos, tipicamente contributivos (Unsworth, 2001), inicialmente intraempreendedores e, posteriormente, criadores de empresas ou negócios.

As questões de pesquisa aqui colocada são: uma vez imersas no cenário de pressão pela inovação, o que leva as organizações a rejeitar idéias ou projetos criativos propostos por empreendedores (as) internos (as)? A resiliência e a crença na causalidade pessoal poderiam explicar o fato de que algumas das pessoas empreendedoras que têm seus projetos ou propostas - criativas - rejeitadas empreendem a criação de empreendimentos inovadores? 
Buscando resposta a essas questões, a estratégia de pesquisa aqui desenvolvida tem por objetivo desvendar o processo criativo - empreendedor - inovador que tem início num ato pessoal, passa por labirintos e veredas que o dificultam ou ajudam a amadurecer, até a realização empreendedora. Busca-se dissecar os elementos e os conceitos neles implicados, ao longo desta trajetória.

\subsection{Componentes deste estudo}

O capítulo I, Introdução, comentou o cenário atual das organizações, do trabalho humano no contexto organizacional e da relação entre empreendedorismo, criatividade e inovação. Os diversos paradoxos atinentes ao imperativo da inovação no universo da vida produtiva, a necessidade de diferenciação e a presença do design como manifestação criativa por excelência foram apresentados preliminarmente e serão aprofundados nos capítulos seguintes.

O capítulo II é dedicado ao estudo do conceito criatividade, abrangendo seu aspecto ontológico e sua utilização como categoria de prática. O capítulo traz as macro-questões tratadas pelos estudiosos "de Guilford a Amabile”, reconhecendo no discurso de J. P. Guilford como presidente da Associação Americana de Psicologia em 1950 um marco teórico do início das pesquisas e em Teresa Amabile, uma pioneira na introdução da psicologia social como referencial para este tipo de estudo e dos estudos que relacionam a motivação intrínseca à criatividade. São discutidas possíveis respostas à pergunta se há uma criatividade ou várias criatividades. O processo criativo, bem como sua avaliação, integra este capítulo. 
O capítulo III trata da caracterização da pessoa criativa, abrangendo uma revisão teórica do conceito de criatividade pelas grandes correntes teóricas da psicologia, bem como a análise da literatura deste campo de estudos sobre a personalidade criativa. São discutidas também as relações entre inteligência, criatividade e sabedoria (Sternberg, 2001).

No capítulo IV, são diferenciados os principais conceitos que compõem o arcabouço teórico deste estudo, a saber, a criatividade, a inovação, a invenção, a descoberta e o empreendedorismo inovador.

O capítulo $\mathbf{V}$ é dedicado a questões específicas da criatividade no ambiente organizacional, tais como o impacto da estrutura, cultura e mudança organizacional sobre as produções criativas, distinguindo neste contexto a criatividade da inovação. $\mathrm{O}$ ambiente ou clima propício à criação e os problemas ligados à pressão para a inovação e a criatividade, além da problemática da avaliação e do erro, especificamente no âmbito das organizações, integram este capítulo.

Os resultados da pesquisa empírica, a estratégia utilizada e as conclusões estão contidos no capítulo VI e as principais conclusões da tese, no capítulo VII. 
Capítulo II 


\section{Criatividade, um conceito plural}

Há consenso na literatura sobre a relação necessária entre criatividade, o novo e a originalidade. Qualquer enquete, mesmo processada fora do rigor de uma pesquisa acadêmica, confirmaria estes fatores. Mas até que ponto se poderia definir o novo como tudo aquilo que difere do que está estabelecido, do que é corriqueiro, cotidiano ou rotineiro? Seria concebível algo ser novo ou original e não ser criativo? Além disso, como reunir num mesmo conceito a criatividade artística, científica, social e comercial? Esses são alguns dos desafios do presente estudo.

Analisar a criatividade como questão teórica requer uma estratégia multidisciplinar, uma vez que ela tem sido estudada como conceito e como categoria de prática, nos campos da filosofia, teologia, sociologia, psicologia, semiótica, arte e literatura, dentre outros, e em cada um desses, um aspecto ou característica do conceito é revelada, incitando a uma síntese. Este é o escopo do presente capítulo, que constitui a base para a discussão da criatividade nas organizações e nos negócios, a ser empreendida nos capítulos seguintes. Ele abordará a criatividade nos diversos campos do saber e como categoria de prática, buscando, no referencial ontológico, a essencialidade do conceito. 


\subsection{A criatividade como questão teórica}

A compreensão da criatividade humana tem sido um desafio em todas as ciências que a incluem em seu objeto. Muitos são os obstáculos e inúmeras as dificuldades, a começar pelas contradições inerentes ao próprio conceito. Há um paradoxo intrínseco que se revela no simples reconhecimento de que, ao definir aquilo que é criativo, seja classificando-o, seja criando categorias, impõem-se limites que não são compatíveis com a liberdade - que se pressupõe intrínseca - ao ato de criar. Além dessa contradição, outra dificuldade bastante conhecida é a de que, não obstante os avanços dos estudos e pesquisas conhecidos, a diferenciação entre o que é criativo e o que não é continua problemática, fonte de contradições entre critérios em campos distintos como a arte, a administração e a ciência social. Se criatividade for assumida no sentido de trazer à existência algo que antes não existia, o conceito é inapropriado para explicar determinados tipos de fenômenos artísticos, ao passo que a não consideração deste mesmo sentido impossibilita a compreensão de inovações radicais. De forma semelhante à resiliência, estudada anteriormente, parece que se está diante de um conceito "fácil de entender, mas difícil de explicar" (Barlach, 2005).

Embora sejam conhecidas as dificuldades para definir o que é criativo, é ainda mais difícil fazê-lo no contexto atual do capitalismo da inovação, no qual a busca pelo novo, pelo diferente e pelo inusual como fator diferencial em todos os níveis torna-se cada vez mais necessária, em especial na esfera dos negócios e da tecnologia. A aproximação à questão conceitual permitirá distingui-lo de outros termos correlatos e constituirá uma bússola norteadora na navegação por este intrincado campo do conhecimento. 
Uma primeira abordagem ao conceito, pela via da etimologia, revela a faceta da criatividade como um ato divino. Criar é definido, nos dicionários, como "trazer à existência ou formar do nada" (Boden, 1999), “tirar do nada” (Michaelis, 1979), “dar existência a", "dar origem a", "formar" (Ferreira, 2000). O mesmo se dá nas línguas grega e latina, em que o vocábulo guarda o significado de "tirar do nada" (Pereira, 1951 / 1990, p.62), "formar, instituir, produzir, causar e gerar" (Torrinha, 1939, p. 338). Porém, na língua hebraica, há dois sentidos, um reservado à criação divina e outro, à humana. Em função da associação freqüente do vocábulo com a criação divina, a análise tem início pela leitura do Gênesis.

\subsubsection{Criação divina, criação humana: o livro do Gênesis}

No Gênesis, primeiro capítulo do livro sagrado das tradições judaica, cristã e muçulmana, está contido o mito corrente no mundo ocidental sobre a criação do mundo em sete dias e o surgimento do casal - Adão e Eva - a partir do qual se desenvolve a humanidade.

A leitura do Gênesis na língua hebraica revela um detalhe interessante: nela, utiliza-se um verbo para o "criar" divino ${ }^{4}$, mas este verbo não é usado quando há referência a outros tipos de criação. O verbo utilizado ao longo da descrição da criação divina não é o mesmo quando da construção do tabernáculo, por exemplo, que o texto atribui a uma obra humana. No hebraico, o verbo criar no sentido divino só é utilizado para as criações da natureza (os frutos da terra) e para a saúde humana. Em ambos, há a presença do novo, mas sua produção é diferenciada quanto ao sujeito criador e o objeto da criação. Seria, então, a capacidade de criação um atributo divino? Reservar-se-ia ao ser humano algum potencial criativo? Haveria uma criação essencialmente divina e outra, humana? O texto

\footnotetext{
${ }^{4} \mathrm{O}$ verbo para a criação divina é LIVRÓ e, para a criação humana, LITZOR (transliteração livre).
} 
bíblico permite inúmeras interpretações, atinentes a distintas religiões e crenças, variando conforme diferentes períodos históricos e seus intérpretes. Assume-se aqui a versão de que o relato bíblico permite supor um convite implícito para que o ser humano seja "parceiro de Deus" no processo de criação, completando a obra divina pela criação de si mesmo e do universo que o cerca, embora seja exclusividade da divindade certa qualidade de atos criativos. A existência dos dois verbos na língua hebraica permite também supor que a importância da criação divina é de tal magnitude que a exclusividade de um verbo para ela é uma maneira de sublinhar a sua importância. Os recentes debates sobre clonagem de seres vivos e outras inovações oriundas de pesquisas da engenharia genética colocam em questão esse aspecto do conceito, ao discutir os limites e possibilidades da criação humana quando confrontada à criação divina, pois, ainda que por meio de processos mecânicos e técnicos e não necessariamente criativos na acepção plena da palavra, o ser humano se confronta com a possibilidade de criar novos seres. Mesmo não sendo objeto desta tese, cabe mencionar o ensaio recente de Habermas (2004) sobre o futuro da natureza humana, em que este discute a questão de identidade daquilo que não tem seu surgimento definido pelo acaso da natureza, mas por um designer.

Bartoli (2008), em sua análise da espiritualidade humana como resposta ao mundo supercapitalista, entende o ser humano como ser criado e criador. Há um mundo criado e, por isso, incompleto, e um chamado do Criador em relação a um futuro infinitamente aberto (p. 201). A espiritualidade humana, para o autor, está associada à oportunidade de conexão ontológica - não apenas moral ou intelectual - das potências humanas e divinas, do singular ao universal (p. 206). O ser humano é, portanto, um ser criado para criar (p. 207), assim entendido: "Criar é ir além da morte; é o conteúdo da visão de Deus; é o sentido da vida" (p. 207). A criatividade, para esse autor, "não é uma exigência, nem um 
direito [do ser humano]: é uma exigência que Deus dirige ao [ser humano]. [Assim,] a audácia criadora é o cumprimento da vontade de Deus" (p. 209). A criatividade é aqui entendida como parte da própria condição humana. “A criação não precisa de justificação, ela é que justifica [o ser humano]". Por isso, "Não se trata de um processo de objetivação: trata-se de uma experiência de transcendência". "O ato criador não consiste tanto em produzir no finito, mas em ultrapassar o finito e levantar vôo em direção [ao] infinito" (p 209). Em outras palavras, sendo um chamado do Criador, uma vocação ${ }^{5}$ no sentido amplo da palavra, apresenta-se aqui uma das inúmeras dificuldades para se definir a criatividade: a infinitude de possibilidades; a imprecisão inerente a qualquer delimitação para o conceito.

A interpretação do texto bíblico e o sentido de alteridade e transcendência possibilitam entender o processo criativo como inerente ao ser humano em geral e dela deduzir que não somente artistas e cientistas são criativos, como muitas vezes é entendido pelo senso comum, mas que esse potencial é acessível a todo e qualquer ser humano. Desse pressuposto deriva o entendimento de que a criatividade está implícita nos processos de adaptação criativa à realidade - como na visão da Gestalt - e de resolução criativa de problemas, proposta por Ruth Noller ${ }^{6}$, conforme se verá adiante.

A diferença entre objetivação e transcendência é o primeiro aspecto da problemática do conceito de criatividade, pois se a objetivação é um ato em que se cria algo novo sem produzi-lo fisicamente (pela complementação da consistência metafísica do objeto, por meio da descoberta de novos significados e sentidos para uma coisa, não envolvendo a

\footnotetext{
${ }^{5}$ A palavra vocação deriva do termo latino VOCARE, chamado, com o sentido de predestinação.

${ }^{6}$ Em Miller et al (2001), encontra-se uma linha do tempo em que é descrita a história da abordagem da resolução criativa de problemas, adotada em muitos centros americanos dedicados ao estudo e desenvolvimento da criatividade, em especial o International Center for Creative Studies, em Buffalo, NY, fazendo referência à Ruth Noller (1978), que teria cunhado este termo.
} 
materialidade; assumindo duas existências num mesmo ser), a transcendência implica, sim, a criação de um ser completo em sua existência, como no caso do bebê humano, concebido a partir de células de seus pais biológicos. Para Bartoli (2008), criar é transcendência porque é entendido como o instituir a alteridade - o outro -, transformar em dois aquilo que é uno, tal como Deus separou luz das trevas e as águas de cima das águas de baixo, criando os céus e a terra, respectivamente. O sentido de alteridade na criação humana pode ser visto quando na união de um casal há a instituição do outro, sendo o bebê representante da alteridade instituída.

A existência do novo sem a participação da materialidade, como por exemplo, no caso da geração de novas idéias, configura uma concepção platônica, que deu origem a inúmeras teorias psicológicas. Por sua vez, a transcendência institui uma alteridade que é separada - materialmente - de seu criador e tem forma tangível, numa concepção aristotélica da criação. Tangibilidade ou intangibilidade? Plano ideativo, psicológico, ou concreto, material? Os dois sentidos metafísicos da criatividade - transcendência ou objetivação devem ser investigados, adentrando o terreno da filosofia pelo acompanhamento, respectivamente, de Aristóteles e Platão, dois pioneiros neste assunto, em suas proposições sobre o tema.

\subsection{Platão e Aristóteles: objetivação ou transcendência?}

Desde a antiguidade, a humanidade tem se colocado diante do entendimento do novo. Filósofos gregos, como Platão, atribuíam a criatividade a um processo com inspiração divina, em que, por meio de uma visão interior, o ser humano se identificava com a razão divina e, a partir daí, apreendia a realidade externa. No momento da criação, o artista 
perdia o controle de si mesmo, passando ao domínio de um poder superior (Platão, s.d., In: Wechsler, 1993).

Em seu texto, “A alegoria da caverna”, Platão (In: Chauí, 1997) discorre longamente sobre o fato de que o ser humano comum está cego e vive na ignorância, tomando como real aquilo que, em verdade, é a sombra do real. Preso a este mundo de sombras, mesmo que lhes fosse dada a liberdade, os humanos nada veriam, pois acostumaram-se à cegueira e à ignorância. Além disso, havia, para Platão, a presença de uma musa inspiradora, mas esta inspiração teria fonte divina, deixando a pessoa "fora de si" no momento da criação (o que, na atualidade, seria denominado de estado alterado de consciência) (Neilson, 2008). Esta é provavelmente a origem de algumas das noções presentes no senso comum acerca da criatividade, associando-a a insanidade, ao mistério ou aos poderes sobrenaturais ou super-humanos. Seguindo o raciocínio de Bartoli (2008), mencionado acima, pode-se dizer que, para Platão, o sentido de criatividade é uma forma de objetivação.

Aristóteles, por sua vez, rejeitava a noção do misterioso ou do sobrenatural ao explicar a criatividade. Distinguia entre as ações que têm um fim em si mesmas daquelas que têm por finalidade a produção de uma obra e dizia que é nas atividades cujo fim é a própria atividade que se pode identificar a excelência e a liberdade. Nelas se incluem a economia, a ética e a política, enquanto nas ações fabricadoras - ou poíesis - aí contempladas a agricultura, a navegação, a pintura, a escultura, a arquitetura, a tecelagem, todos os artesanatos, além da poesia e da retórica -, o mesmo não se dá.

“Toda arte (téchne), toda investigação (méthodos), toda ação (práxis) e toda escolha racional (proaíresis) tendem para algum bem (...). Mas observa-se, de fato, 
uma certa diferença entre os fins: uns consistem nas atividades, outros em certas obras, distintas das próprias atividades" (Aristóteles, s.d., In: Chauí, 1994, p. 234).

A práxis para ele era, portanto, superior à poíesis, em função da liberdade daquilo que tem em si mesmo o sentido e finalidade (Chauí, 1994, p. 234). Para Aristóteles, portanto, o agir humano abrigaria dois tipos de ação, uma voltada à produção e outra, à orientação do sentido, mas pode-se dizer que a criatividade guardaria associação com a práxis, sendo, portanto, de natureza superior.

Se, para Platão, a criação está nas sombras, não envolvendo compromisso com as formas, podendo, nesse comprometimento, representar inclusive a loucura, para autores como Ostrower (1977), pelo contrário, a criatividade está associada a "dar forma" e, nesse sentido, a análise de Aristóteles sobre a matéria e suas considerações sobre o devir, a potência e o ato completam o olhar sobre o conceito em seus desdobramentos ontológicos. Para Aristóteles, a matéria é o princípio de individualização dos seres, enquanto a forma é o princípio de especificação (espécie) e generalização (gênero) dos seres. Isto significa que a forma é o princípio de diferenciação dos seres, enquanto a matéria os individualiza (Chauí, 1994, p. 283). As formas estão inscritas na matéria e a única existência em forma pura, ou seja, imaterial, é Deus. A matéria é o princípio da mudança ou, em outras palavras, "o princípio da mudança (o devir, o movimento, a Kínesis) é a matéria" (Chauí, 1994, p. 283, grifos da autora). Por isso, os seres compostos de matéria e forma mudam ou passam de uma forma a outra, desenvolvendo a forma que possuem. "Todo ser move-se ou muda porque aspira ou deseja a imobilidade [...] Todo ser aspira à perfeição da forma pura que não muda nunca. Todo ser aspira à identidade total consigo mesmo" (p. 284). Assim, 
de mudança em mudança cada ser se aproxima [...] de sua finalidade ou de sua forma perfeita.

“A forma [...] é o real (o atual); a matéria, por ser sempre uma potência, é o possível (o que pode ser, o que vem a ser). A cada momento, uma substância tem a realidade de sua forma e a possibilidade de sua matéria, de forma que o que ela vier a ser, a nova forma que ela tiver, já está presente como uma possibilidade desta substância porque é uma potencialidade de sua matéria" (Chauí, 1994, p. 284, 285). Assim, há sempre a possibilidade de atualização do possível e o devir pode ser conhecido, pois sua causa final é a atualização plena das potências da forma que estão aprisionadas na matéria. O devir é trans-formação, da potência ao ato (p. 283). Todo ser humano, ao confirmar a incompletude, é criador, reconhecendo o mundo como conjunto de potencialidades. Cada pessoa desenvolve, então, diferentes instrumentalidades para fazer uso das potências do mundo. Em outras palavras, se, por um lado, o ser humano foi criado para completar a criação, por outro, a criação é sempre completável.

A exploração das potencialidades de relações entre matéria e forma define o criar em Aristóteles, assemelhando o agir humano - a práxis - ao ato divino, em que a matéria é individualizada na forma, instituindo a alteridade. Ou seja, se para Platão o mundo é das idéias e das sombras e o novo se produziria pela objetivação, para Aristóteles, a consideração acerca da materialidade permite identificar a transcendência. Objetivação e transcendência são duas possibilidades de compreensão metafísica (ou ontológica) a partir das quais será possível analisar muitas das abordagens atuais acerca da criatividade. Na objetivação, a atualização do possível envolve apenas a forma, ao passo que na 
transcendência, matéria e forma. Devir, movimento permanente que não permite interrupção, é que leva tanto à objetivação quanto à transcendência.

Entretanto, para além dos (as) estudiosos (as) que associam a criatividade ao fazer divino e, consequentemente, ao surgimento do novo a partir do inexistente, há uma outra linha de pesquisa que entende a criatividade como combinação, integração ou rearranjo de elementos existentes previamente. Complica-se, assim, a análise, uma vez que se considera que os mesmos elementos podem constituir o novo a partir de uma atualização do possível que altera apenas propriedades dos elementos combinados. Esses rearranjos ou combinações não são uma forma de objetivação, pois alteram significativamente os componentes da matéria. Os mesmos elementos, combinados em novos arranjos, podem atender tanto ao critério de objetivação quanto ao de transcendência. Seriam diferentes conotações para a mesma palavra ou haveria alguma distinção fundamental entre tais abordagens? Para além da compreensão metafísica, passa-se agora a analisar as visões compreendidas nas categorias de prática.

\subsection{Uma outra ordem de critérios: o conceito de criatividade como categoria de prática}

Tendo discutido a objetividade e a transcendência como parâmetros essenciais para a análise da criatividade humana, abordam-se, a seguir, outras conceituações que não dizem respeito propriamente à sua natureza ontológica, mas fazem parte do senso comum ou são utilizados como categoria de prática. Para além das questões metafísicas, os (as) estudiosos (as) se concentraram na tentativa de compreender a criatividade como uma categoria de prática, propondo taxonomias. Categorias de prática e de análise se 
sobrepõem, configurando um rico mosaico. Aqui será discutida a criatividade como combinação de elementos, além da geração de novos significados e do fator estético.

\subsubsection{A combinação de elementos}

A partir da teoria evolucionista de Darwin, a geração do novo passou a ser explicada pela inesgotável capacidade de combinações entre genes, produzindo variedades de formas sem repetições (Wechsler, 1993). As ciências naturais, como a química e a biologia, exploram amplamente este aspecto do conceito, ao analisar determinadas reações capazes de gerar sínteses a partir das quais os elementos passam a não mais ser reconhecíveis. O exemplo clássico é da água, resultante da combinação de hidrogênio e oxigênio, na qual já não se identificam - a olho nu - esses componentes. Na química e, por vezes também na genética, a mudança transforma elementos e, a partir da mudança, são alteradas suas propriedades fundamentais; gera-se um outro conjunto de propriedades a partir da combinação. Mesmo quando os elementos se repetem, a própria condição de estarem combinados altera significativamente as propriedades e os elementos iniciais transformamse em outros seres. Assim, a idéia de combinação como explicativa da criatividade assemelha-se à noção de práxis, exposta acima, com significado de transcendência, em alguns casos, mas parece constituir um novo critério, em função de sua base empírica, ou seja, uma categoria de prática, se comparada às categorias metafísicas discutidas anteriormente.

Alguns estudiosos da criatividade buscaram resolver o problema do critério propondo distinguir a criatividade "maior" da criatividade "menor". Enquanto a primeira se aproximaria da divina, a segunda seria associada às criações corriqueiras, cotidianas, 
acessíveis a todos os indivíduos, derivadas de rearranjos de elementos. Três autores representam esta tendência: Margaret Boden, Howard Gardner e Todd Lubart. Boden (1999) intitula a criatividade P quando esta tem valor para pessoa que cria, não importando quantas outras pessoas já teriam tido a mesma idéia e criatividade $\mathrm{H}$, quando, em toda a história da Humanidade, ninguém teve a idéia antes. Gardner (1996) denomina criatividade C-maiúsculo aquela que pode ser atribuída aos grandes mestres e cientistas e a criatividade com c-minúscula, aquela que poderia ser encontrada nas dimensões da vida prática e do cotidiano. De forma semelhante, Lubart (2007) adota os termos criatividade cotidiana ou eminente entendendo, como Gardner, a existência de um continuum entre uma e outra e afirmando que ambas teriam por base o mesmo processo.

Seriam, então, tais distinções atribuíveis a uma questão de valor? Para caracterizar uma criação como menor ou maior, eminente ou cotidiana, não é a criatividade em si que está sendo avaliada e, sim, seu impacto social, econômico ou se seu uso cotidiano facilita a vida, por exemplo.

Embora as proposições de Boden, Lubart e Gardner não tragam uma solução para o problema da conceituação da criatividade, têm o mérito de incorporar as inúmeras criações cotidianas que se processam continuamente, além de introduzir o elemento de valor da criação, que será discutido mais adiante. No entanto, esse tipo de tratamento da questão amplia tanto o que é criativo que permite englobar qualquer tipo de processo, o que, ao invés de esclarecer, traz à tona mais dificuldades conceituais. É até mesmo possível que a criatividade $\mathrm{P}$ e c-minúsculo sejam mais próximas ao conceito de novidade do que, propriamente, da criatividade, uma vez que a novidade refere-se a informações, dados, 
elementos ou objetos que não faziam parte do repertório de um determinado grupo, mas que podem não ser novas em outro contexto.

Cabe, então, perguntar: em que aspectos há diferenças ou semelhanças entre a novidade e a criatividade? Se a criatividade for considerada como a elaboração do novo a partir do nada ou a instituição da alteridade (Bartoli, 2008), a novidade, como também a entende o senso comum, diz respeito às alternativas empregadas para a variabilidade cotidiana, à opção de "fugir à rotina", sem que ocorra a criação, propriamente, de algo novo. É comum, em pequenos negócios do ramo alimentício a proposição do "cardápio do dia", elencando as "novidades". Aí não se poderia falar propriamente de criatividade, mas de pequenos arranjos que enfatizam ora um, ora outro elemento pré-existente. Muito utilizada nas ações publicitárias, a novidade em si nem sempre muda ou institui o outro, afastandose do sentido de transcendência que a criatividade pode alcançar.

Na concepção da criatividade como combinação de elementos, é importante distinguir a mudança na permanência, da permanência na mudança, esta última significando a novidade e não a criação do novo. Tome-se, por exemplo, na culinária, a elaboração de um prato denominado nhoque. Alterando-se um dos ingredientes, ter-se-á o nhoque de batata ou de mandioquinha, num rearranjo que mantém elementos. A tradição deste prato é a utilização de batata. Logo, o uso de mandioquinha seria uma novidade, mas ele ainda assim seria considerado nhoque. Aqui, o novo não é radical, mas apenas uma alteração de ingredientes.

Numa busca de solucionar a questão, Boden (1999), além de entender o ato criativo como combinação de elementos, enfatiza a improbabilidade desta, embora reconheça que não 
se tem uma explicação convincente sobre como esta surja. Outros autores, como Aktouf (1996) se apóiam na teoria da análise combinatória para entender o fenômeno enfatizando que "as capacidades de combinações (associações) aumentam vertiginosamente desde que se aumente, mesmo que pouco, o número de elementos a combinar" e acrescentam, a partir daí, a importância, na época atual, de uma formação geral, variada e contínua dos profissionais do mundo moderno, como meio de ampliar o número de elementos a ser combinados (Aktouf, 1996, p. 153).

A explicação da criatividade pela capacidade de combinação de elementos para gerar o novo apresenta, além do que já foi dito acima, um outro problema, quando coloca a estatística ou a probabilidade como critério para a sua identificação. No entanto, mesmo admitindo que as combinações novas fossem raras do ponto de vista estatístico, ainda permanece a pergunta sobre porque um arranjo diferente é algo novo e criativo e, ainda, se basta que as mesmas peças sejam combinadas diferentemente para gerar aquilo que é novo. Além disso, o tratamento como novidade e as categorizações maiúsculo minúsculo, $\mathrm{P}$ ou $\mathrm{H}$, não impactam o conceito em sua essencialidade; enquanto categorias de prática, resultam em maior confusão quanto aos critérios. A abordagem gestáltica, discutida a seguir, propiciará um enriquecimento desta visão, agregando o aspecto dos novos significados que podem ser atribuídos a elementos previamente existentes.

\subsection{Novas Gestalts: a dinâmica da subjetividade}




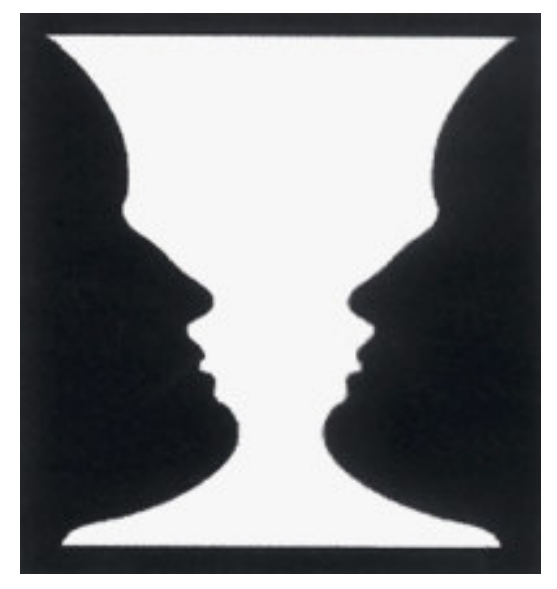

Figura: Um cálice ou dois rostos?

(http://www6.ufrgs.br/psicoeduc/gestalt/figuras-sobre-psicologia-da-gestalt/)

A discussão acerca do conceito de criatividade não se encerra com a abordagem do aspecto ontológico ou das combinações e rearranjos de elementos. Dentre as várias teorias psicológicas que abordaram a questão, a Gestalt é aqui destacada em função de estudar a criatividade no processo da adaptação humana em sua dependência da produção de novos significados a partir da flexibilização e diferenciação da figura com relação ao fundo ou contexto e vice-versa. É o que a seguir se comenta.

Os fundamentos da teoria da Gestalt foram propostos por Wertheimer, Koffka e Kohler na Alemanha, no início do século XX. Seus estudos experimentais tinham foco na percepção, pensamento e solução de problemas. Wertheimer (1959, In: Alencar, 1993) contribuiu para a compreensão do ato criativo, especialmente em sua pesquisa sobre o pensamento produtivo que, segundo ele, requer uma reestruturação do problema e implica o exame do contexto e a apreensão dos fatores e requisitos estruturais, podendo o pensamento gerado provocar mudanças na situação, visando aperfeiçoamentos na estrutura de um problema, por exemplo. 
Gestalt, de acordo com Koffka (1975), refere-se a uma configuração, "tem o significado de uma entidade concreta, individual e característica, que existe como algo destacado e que tem uma forma ou configuração como um de seus atributos" (p. 691). A relação da criatividade com a forma (ou configuração) remete à discussão do conceito de figura fundo que também faz parte dos fundamentos que subjazem a esta teoria. Há consenso entre os teóricos da Gestalt de que o ser humano não percebe elementos separados, mas estabelece relações entre figura e fundo que, uma vez deslocados, podem criar novos significados, conforme a figura 1, acima. A psicologia da Gestalt é uma psicologia de campo que reconhece que totalidades são mais que somatórias de partes isoladas, pois "qualquer mudança em uma das partes afeta o sistema inteiro" (Smith, 2007, p. 3). Sob o ponto de vista do indivíduo, a percepção é sempre um processo criativo, em que objeto e contexto assumem distintas conexões causais, quando percebidos como fundo ou figura. Também para a psicologia da Gestalt, significantes e significados são intercambiáveis, fazendo do indivíduo percebedor um produtor permanente de sentidos.

No contexto da figura e fundo, uma "boa forma" é "aquela que persiste e tende a tornar a acontecer" (p. 4), mas há também o conceito de "forma forte", coerente e resistente à desintegração "por meio de análise ou fusão de outras formas" (p. 4). Uma forma que é tanto boa quanto forte é dita "forma fechada, em contraposição à forma aberta que tende em direção ao fechamento ao ser completada como boa forma” (p. 4). A Gestalt, no sentido de forma ou totalidade, "tende a ser estável", ou seja, tende a persistir ou ocorrer novamente caso a situação seja reinstalada ou mesmo se uma parte da Gestalt reaparecer. Esta tendência à preservação é denominada "constância do objeto". Uma vez que a organização, a forma e o caráter do objeto dependem das relações entre suas partes, fica claro que a mudança de contexto - fundo - leva à busca da boa forma. A lei de Pragnanz, 
subjacente a estes mecanismos, prevê três tipos de rearranjos em direção à boa forma, a saber: o nivelamento, referente à mudança na organização do campo em direção à simetria e boa distribuição; o aguçamento, que envolve a acentuação dos elementos essenciais da figura e a normalização, que diz respeito a tornar a Gestalt clara e simples (Smith, 2007, p. 4). A teoria busca ainda explicar a desconstrução de um objeto, mas alerta para o fato de que, mesmo neste caso, não se perdem de vista as dinâmicas que conectam os diferentes níveis em que o objeto está organizado.

A teoria da Gestalt ainda associa a criatividade ao fenômeno do insight. Em Kohler, encontram-se vários experimentos sobre aprendizagem que, em contraposição à aprendizagem por ensaio-e-erro, supõem a noção de insight, situação de iluminação em que a solução do problema surge de maneira inesperada no momento em que o sujeito tem sua atenção voltada para outros assuntos. O tema do insight é retomado por autores mais recentes da abordagem gestáltica, que o qualificam como um salto criativo, em que "alguma coisa reverbera dentro da pessoa e muda toda a sua concepção do problema a ser resolvido" (Nachmamovitch, 1993, p. 10), guardando associação com o tema da serendipidade, que será tratado mais adiante. É importante aqui ressaltar a presença dos inúmeros insights cotidianos de difícil reconhecimento, seja por parte do indivíduo, seja pelos agentes do reconhecimento da criatividade. Distinguir o novo, oriundo dos pequenos insights, em meio ao rotineiro, é tarefa difícil, mas a constatação da presença desses fenômenos criativos corriqueiros indica a presença permanente da criatividade no psiquismo humano.

Koestler (1964), um dos autores dessa mesma tendência teórica, entende o ato criativo a partir de habilidades mentais ou universos de discurso que são integrados e transformados 
em nova síntese - outra expressão para o insight, acrescentando que "o ato criativo pode ser descrito como a mais elevada forma de aprendizagem, em função da alta improbabilidade [...] de solução" (p. 657). Considera que a criatividade provém do fato de que estas novas sínteses derivam de campos anteriormente independentes ou afastados e que, a partir de então, torna-se difícil reconhecê-los separadamente. "Quando duas estruturas de conhecimento tornam-se integradas numa só, fica difícil imaginar que antes elas existiam separadamente [...] A síntese parece auto-evidente” (p. 658). A idéia de Koestler de que, ao produzir uma nova síntese, não é mais possível identificar os componentes que foram combinados é bem evidenciada nas reações químicas, como se disse anteriormente: a água é um elemento novo, criado a partir da reação produzida entre duas moléculas de hidrogênio e uma de oxigênio, mas, nela, não é mais possível identificá-los. As mesmas moléculas - hidrogênio e oxigênio -, combinadas diferentemente, podem produzir o ozônio, por exemplo, com propriedades resultantes completamente diferentes das da água. Este autor cunhou o termo bissociação para se referir às características de independência e autonomia das matrizes que são colocadas em contato pelo ato criativo, contrapondo-o ao pensamento associativo, que operaria entre membros de uma só matriz pré-existente.

Na concepção de Koestler, matrizes são sistemas de referências, contextos associativos, tipos de lógica ou universos de discurso. Referem-se a qualquer habilidade, hábito ou padrão ordenado de comportamento governado por um "código" de regras fixas. Ele exemplifica com o jogo xadrez no qual a matriz é o padrão que está à frente do (a) jogador (a), representando o conjunto de possibilidades de movimentos permitidos. O código que governa a matriz pode ser descrito a partir de equações matemáticas que contém a essência do padrão, podendo ser expresso pela palavra "diagonais". O código é o fato fixo, 
invariável no hábito ou habilidade; a matriz, seu aspecto variável. As duas palavras não se referem a diferentes entidades, mas a diferentes aspectos da mesma atividade. Frente ao tabuleiro de xadrez, o código é a regra do jogo que determina os movimentos que são permitidos; a matriz é o total das possíveis escolhas. A escolha de dado movimento dentre a variedade de movimentos permitidos é questão de estratégia, guiada pela posição ou o ambiente dos outros jogadores de xadrez em dado instante.

Uma vez que a matriz se torna completamente automatizada, o código por si só determina qual membro deve atuar e em que ordem. Aí, a criatividade não opera. Koestler se utiliza do exemplo de um indivíduo que sempre usa o mesmo caminho para o escritório, informando que sua estratégia é fixa e perene e já está integrada ao código. Embora a idéia de automatismo pareça paradoxal quando pensada a partir do conceito de criatividade, é necessário considerar a existência, no organismo humano, de múltiplos sistemas em operação e, a predominância, em parte deles, de processos neurológicos automáticos; do ponto de vista global, estes últimos são tão necessários ao ser humano quanto aqueles de ordem superior, descritos na bissociação (Koestler, 1964).

A partir da idéia de bissociação ou associação, Koestler diferencia hábito de originalidade, conceituando hábito como associações feitas dentro dos limites de uma dada matriz e originalidade como a bissociação de matrizes independentes (1964, p. 660). Para ele, há um lado revolucionário ou destrutivo no ato criativo, pois, independentemente do período histórico analisado, cada [trabalho artístico] desafia o olhar preconceituoso, que é governado por códigos seletivos (p. 380). Um ato criativo envolve um código individual que desvia das regras convencionais - uma nova maneira de bissociar meios e motivos. 
Para o autor, originalidade é o antônimo de rotina, estando a primeira vinculada a um processo de bissociação e a última, à associação (Koestler, 1964, p. 656, 657).

O conceito de criatividade, para a Gestalt, é objetivação, relação entre matriz e código, escolha de ação que leva em consideração os elementos do contexto e o conjunto de possibilidades em jogo em determinado instante.

Quanto à adaptação humana e considerando a tensão entre a pessoa e seu meio ambiente, a psicologia da Gestalt entende sucessivos estágios de diferenciação e integração para a auto-expansão e auto-realização, sendo esta última o "motivo soberano do organismo, [...] a tendência criativa da natureza humana em que a pessoa desvela seu potencial para o campo do atual" (Smith, 2007, p. 6 e 7). Atualizar, aqui, tem o sentido de viver o aqui-eagora e relaciona-se à saúde mental, em contraposição a fixações e cristalizações seja para com a figura, seja para com o fundo, que caracterizariam a neurose. Autonomia ou autodeterminação - expansão do organismo pela assimilação e domínio cada vez maior de seu ambiente e homonomia ou entrega - ajustar-se ao ambiente e participar de algo maior que o self, são os dois componentes da adaptação criativa.

A teoria da Gestalt refere-se ao ajustamento criativo adicionando a noção de mutualidade neste ajustamento, a partir de uma perspectiva de campo. Neste sentido, o ajustamento vem a ser um dar-e-receber, podendo o indivíduo alterar o ambiente - até refazê-lo ou criá-lo diferentemente - bem como mudar a si mesmo para se encaixar nele. Assim, o ajustamento criativo é, essencialmente, uma visão de crescimento saudável. Nas palavras de Latner, ajustamento criativo é "usar a competência e a energia para estender a fronteira do que é possível em qualquer campo da vida e em qualquer nível de complexidade" 
(Latner, 2003, p. 74). Vida saudável é permeada de improvisação, composta de um ato criativo após o outro, ao passo que neurose é o aprisionamento em padrões repetitivos e inflexíveis. A atitude de refazer o ambiente é associada ao significado de ser um humano na civilização ocidental e pode ser considerada como extensão das idéias do Iluminismo e da força do Humanismo. O conceito de adaptação criativa da Gestalt é revolucionário, em função de introduzir a mutualidade como parâmetro, podendo o indivíduo administrar o que aceitar por parte das solicitações ambientais e o que preservar em sua identidade. Como se verá no capítulo VI desta tese, esse aspecto foi identificado na pesquisa empírica elaborada para esta tese como característica dos indivíduos entrevistados.

Para a Gestalt, então, este tipo de ajustamento representa um modo de ser que é capaz de abraçar a incerteza e ser receptivo à imaginação e à inteligência criativa, uma condição de disponibilização para as figuras que emergem e envolvem a vida, a partir de uma atitude de colocar-se a serviço da figura, vivendo numa unidade com o resto do campo. Portanto, a partir do referencial gestáltico, pode-se afirmar que criar é mais que resolver problemas: é também elaborar novos significados, o que condiz com estudo anterior sobre a resiliência em que se afirmava que "a resiliência pode ser entendida como resposta criativa diante da crise, aplicação do pensamento lateral na geração de soluções inovadoras diante de situações traumáticas ou adversas ou a reconfiguração interna, pelo sujeito, de sua própria percepção e de sua atitude diante da vivência da condição da adversidade ou trauma, gerando crescimento pessoal, constituindo-se numa reação que transcende os limites de um mero processo de adaptação" (Barlach, 2005).

A reunião do conceito de adaptação criativa com o de resiliência enfatiza o fato de que a adaptação requer a reconfiguração interna, sendo consistente com autores como Baxter 
(1982), mencionado no capítulo V, para quem adversidade não é ameaça; é desafio. Ou seja, o ser humano que administra sua própria subjetividade diante das crises se renova como pessoa, reafirmando-se como sujeito de sua história e de sua adaptação.

\subsection{Criatividade: um conceito multifacetado}

Sintetizando o estudo do conceito de criatividade até aqui realizado, é possível identificar pelo menos três maneiras distintas de conceber a criatividade. A primeira delas refere-se a um fazer semelhante ao divino, trazendo à existência o inexistente, instituindo a alteridade na ausência de modelos, guardando significado transcendente. A segunda possibilidade do conceito parte do reaproveitamento de potencialidades de cada elemento que, uma vez combinados, geram novas funções ou enriquecimento das anteriores. Na terceira - a teoria da Gestalt - há referências às duas possibilidades anteriores, diferenciando-se delas pela introdução de um significado específico para o processo de objetivação. Uma das grandes contribuições da teoria da Gestalt é o entendimento de que o processo criativo, intrinsecamente referido à objetivação, pode ter múltiplos significados para o indivíduo que cria, pois, ao deixar a sua marca, sentir-se autor, o indivíduo institui uma alteridade. A identificação de pequenos insights cotidianos e da produção de novos significados aponta para a presença permanente da criatividade na vida humana.

Ainda do ponto de vista ontológico, se Platão afirmava a autonomia da forma em relação à matéria, abrindo caminho para o idealismo e para todas as interpretações da criatividade como delírio e ilusão, Aristóteles aborda a forma como elemento criador. A Gestalt acrescenta à forma o vigor libertário desta, ao abranger a flexibilidade da percepção figura 
- fundo, a instituição permanente de novos significados e o insight como expressão da forma incompleta, pela carência de operacionalidade.

Como se verá no capítulo seguinte, as diferentes visões sobre a criatividade constituem os parâmetros de referência para a análise das descobertas, invenções e inovações. Ver-se-á também que todos os significados do conceito até aqui estudados podem ser aplicados à análise da adaptação humana, no sentido de exploração da potencialidade das coisas do mundo, do uso diferente da mesma coisa, da recriação das formas e da desacomodação do olhar em relação ao cotidiano e à rotina. Na busca de novas Gestats, pela via da adaptação criativa ao universo, o indivíduo resolve conflitos e tensões e, a partir da exploração, aprende novas potencialidades, abre novas possibilidades de vida e tem prazer (Lowen, 1984). O fator estético expressa uma dessas potencialidades, mas deve ser destacado neste estudo em função de sua importância quer para a compreensão do conceito de criatividade, quer para o momento atual das organizações e dos negócios, em que, sob a forma de design $^{7}$, ganha espaço na construção dos diferenciais competitivos destas. Agrega-se outro elemento aos critérios já analisados: o belo.

\subsection{A dimensão estética}

Qualquer tentativa de estudo do conceito de criatividade terá que enfrentar os elementos ontológicos e psicológicos, mas não pode prescindir de analisar o fator estético, que representa aquilo que mobiliza uma emoção, seja esta positiva _ de aceitação _ ou negativa _ de desprazer ou desgosto. Sabe-se que, muitas vezes, o novo desperta emoções

\footnotetext{
${ }^{7}$ A estética não está presente somente no design; ela permeia a arquitetura, a comunicação, as peças publicitárias, a música, e inúmeras outras atividades humanas. $\mathrm{O}$ design aqui se destaca em função de ser uma das formas em que a dimensão estética se faz presente nas organizações, um universo do qual ela esteve ausente por razões históricas que serão comentadas a seguir.
} 
negativas porque representa uma ruptura com aquilo que é conhecido ou está cristalizado em dado contexto. Assim, por exemplo, Marcel Duchamp, ao expor um vaso sanitário como obra de arte, encontrou críticos e opositores ferozes. Da mesma forma, no âmbito das inovações sociais, uma decisão da Prefeitura de Seul, Coréia, de derrubar pontes e viadutos a fim de recuperar um rio que cruzava a cidade despertou, ao menos inicialmente, sentimentos de rejeição por parte da população local.

A análise do elemento estético se justifica em função do fato de que há determinadas ações que são sempre criativas do ponto de vista ontológico, mas devem ser avaliadas como tal, a partir desse parâmetro e este é o caso dos filmes, livros e demais produtos da indústria cultural $^{8}$.

Um dos autores que se dedicou ao fator estético foi Laurent Jullier (sem data), que analisa os parâmetros de "um bom filme", identificando quatro características que, assume-se aqui, podem ser extensivas aos demais produtos desta indústria, a saber: a) originalidade: uma obra é original durante um determinado tempo, até que a prova contrária seja estabelecida; b) coerência: capacidade da obra de ligar suas características formais às suas exigências; o fundo que remonta à figura; c) ser edificante: trazer uma lição; ser exemplar, virtuoso ou bom exemplo; d) ser emocionante: despertar a emoção.

Os três primeiros fatores anteriores referem-se a parâmetros cognitivos e, segundo o autor, a emoção, o único critério não cognitivo, é aquilo que provoca uma reação, um movimento no corpo, mesmo que no campo da indignação. Uma vez que o elemento estético diz respeito à mobilização de uma emoção, é necessário considerar que, para ser criativo, além

\footnotetext{
${ }^{8}$ A terminologia "indústria cultural" vem sendo questionada e, em seu lugar, aplicado o conceito de "indústria criativa" (Bendassolli et al., 2009). Optou-se por manter o termo "indústria cultural" em função de sentido crítico proposto pelos teóricos da Escola de Frankfurt.
} 
de estabelecer novas combinações ou arranjos de elementos, suscite tal movimento. A dimensão estética - busca de perfeição ou equilíbrio da forma - integra, então, a criatividade, suscitando emoção, movimento em direção ao exterior do indivíduo.

Para aprofundar a compreensão do elemento estético da criatividade, é necessário recorrer a Winnicott (1975) e ao conceito de espaço transicional, uma vez que a experiência estética será definida como fenômeno que emerge neste espaço. Nicholsen (2006) entende que a experiência estética não é restrita à arte e aos (às) artistas, mas, ao contrário, é pervasiva a toda vida humana, uma vez que se trata de uma dimensão subjetiva da experiência, não-patológica, em que se processa uma relação idealizada com objetos internos. Baseado na idéia winnicottiana de que o espaço transicional é a base fundamental da experiência cultural ${ }^{9}$, Hagman conceitua que a idealização é um processo no qual o sujeito investe valor em algo que é experimentado como externo a ele. Esse valor não é, portanto, objetivo, pois aquilo que é um objeto idealizado de uma pessoa é, talvez, algo indiferente para outra. Haveria uma experiência proto-estética, definida como "a experiência de perfeição formal do objeto interno arcaico [...] um aspecto da idealização arcaica" [...] dependente de algumas qualidades apreendidas na relação mãe-bebê (Hagman, 2005, p. 35 In: Nicholsen, 2006) e os contextos sociais e culturais, do ponto de vista estético, seriam "extensões das experiências estéticas [primitivas] com a mãe” (p. 151).

Mas não só harmonia e idealização comporiam a experiência estética. $\mathrm{O}$ autor entende que os sentimentos de feiúra e do sublime não podem ser desconsiderados e, nesse sentido, considerações sobre trauma e destrutividade levam a uma versão kleiniana, revisitada pelo

\footnotetext{
${ }^{9}$ Winnicott ensina que estes recebem esta denominação porque correspondem "à transição de um estado em que o bebê está fundido com a mãe para outro em que está em relação com algo externo e separado". A abordagem winnicottiana será explorada em mais detalhes no capítulo III desta tese.
} 
autor, sobre os poderes de reparação do objeto interno, que também deveriam ser consideradas.

Além das dificuldades puramente teóricas atinentes à definição do conceito de criatividade abordadas até aqui - ontológica, combinatória, gestáltica e estética -, a análise se torna mais complexa ao se considerar a relação entre a criatividade e seu contexto, ou seja, seus aspectos psico-sociais. A necessidade de referenciar o ato criativo com relação a uma dada cultura ou contexto específico é um dos elementos consensuais encontrados na literatura. Reconhece-se não ser possível definir criatividade em si, e aponta-se para a necessidade de entendê-la tendo em vista o parâmetro sócio-cultural em que esta está inserida. $\mathrm{O}$ ato criativo $^{10}$ se depara agora com a intersubjetividade característica do contexto cultural.

\subsection{Abordagem psico-social do fenômeno criativo}

A criatividade, analisada a partir da psicologia social, abrange a relação do ato criativo e da pessoa criativa com seu contexto social, político e econômico. Se em alguns momentos históricos, a criatividade é objeto de perseguição política, em outro, ela é incentivada e é demandada para o avanço econômico de uma nação. Sob a ótica cultural, alguns gestos e ações são considerados criativos em uma cultura e são proibidos em outras.

Retomando as bases da teoria de campo, proposta por Kurt Lewin (1994, citado por Lubart, 2007), Lubart afirma que o ato criativo pode ser entendido a partir de uma abordagem sistêmica considerando, no plano do indivíduo, os processos cognitivos, os traços de personalidade e a motivação; no campo, as pessoas que controlam ou

\footnotetext{
${ }^{10}$ Em função do fato de que algumas destas proposições adotam a terminologia "ato criativo", por entender que ele representa a intersecção entre a pessoa que cria e o contexto em que a criação está inserida, este termo será mantido na análise que se segue.
} 
influenciam uma área, que avaliam e selecionam as novas idéias e na área, o saber cultural que engloba as produções criativas e pode ser transmitido de uma a outra pessoa. Nesta proposta, o indivíduo é influenciado ao mesmo tempo pelo campo e pela área e pode desenvolver mudanças nos outros sistemas.

Uma abordagem psico-social da criatividade desvenda a conexão intrínseca entre o ato criativo e a cultura o que, por um lado, revitaliza permanentemente este ato, mas, por outro, concede a este o estatuto da subjetividade, impossibilitando generalizações que extrapolem a subjetividade compartilhada que é a cultura. É importante observar que cada cultura tem uma concepção própria do ato criativo (Lubart, 2007), estabelecendo critérios do que seja criativo, e que a conceituação de criatividade como a capacidade de produzir um trabalho ao mesmo tempo novo e satisfatório em relação às pressões contextuais é de origem européia, pois esta considera a natureza tangível do ato criativo, a partir da idéia de que o processo criativo dá lugar à produção de um objeto e as características deste são medidas por julgamentos consensuais de pares ou especialistas (Amabile, 1996) ou as respostas são comparadas a índices de originalidade em determinada amostra.

Lubart entende que a concepção da criatividade centrada no produto criativo é ocidental, como um movimento linear em direção a um aspecto novo e que a origem desta concepção é relacionada ao Gênesis, quando este descreve a criação do mundo em seis dias, pois na narrativa, cada dia se traduziu em produções significativas (formação de terras, criação dos animais, etc.). Também no Gênesis existe a noção de um início preciso - o nada - em direção a um produto concreto - o universo - que o Criador julgou satisfatório ${ }^{11}$. Mas, ao estudar a noção de criatividade presente nas culturas orientais ou asiáticas, Lubart (2007) constatou que esta era menos ligada à elaboração de produtos novos e mais à

\footnotetext{
${ }^{11}$ VE HAIA TOV, que poderia ser traduzido como "E foi bom".
} 
autenticidade do processo de descoberta, no sentido de realização daquilo que faz parte da natureza essencial do indivíduo. Descrevia-se um estado de plenitude, pelo estabelecimento de uma relação com o mundo original [ou de uma relação original com o mundo] e a expressão profunda de si mesmo. Segundo este autor, a concepção oriental da criação não é marcada por início e fim, mas por um desenrolar ou desenvolvimento de um processo permanente e a idéia de ciclo. Lubart (2007) refere-se ao estudo sobre pintores indianos realizado por Maduro (1976, In: Lubart, 2007), para concluir que a idéia de novidade e originalidade está presente em todas as culturas, mas seu conceito e significado talvez não sejam os mesmos.

Também a promoção ou proibição da atividade criativa é impactada por variações culturais, segundo a importância dada ao indivíduo ou à coletividade (na cultura individualista, o indivíduo é considerado um autônomo e independente, ao passo que, nas culturas coletivistas, a pessoa é sempre pensada em relação a seu contexto social). A cultura influencia o modo pelo qual o indivíduo vai procurar se diferenciar de outros membros de sua comunidade e adotar condutas mais ou menos conformes às regras comuns, remetendo à dimensão individualismo - coletivismo e ao lugar ocupado pelo respeito às tradições. Em certas culturas há maior permissão para a expressão de condutas que se afastam das normas tradicionais. Lubart (2007) aponta também relações entre nível de conformismo ou dogmatismo e criatividade.

Se os elementos associados à criatividade são a perseverança, a tolerância, a ambigüidade e a capacidade para o risco e se a cultura ocidental difunde idéias como "Divertir-se é reservado às crianças"; "fantasia é perda de tempo"; "A lógica e o sucesso são positivos; a intuição, as emoções e o malogro, negativos", passa-se a não favorecer a criatividade. Por 
sua vez, a cultura oriental permite a originalidade nas esculturas de objetos seculares, mas a proíbe nos objetos religiosos.

A partir de um enfoque psico-social, é possível afirmar que a criatividade é um conceito antônimo ao das estereotipias e conformismos. Segundo Sassenberg \& Moskowitz (2005), "ser criativo implica a tentativa de evitar as rotas convencionais de pensar e, portanto, evitar a ativação de associações típicas" (p. 507). Entendendo a estereotipia como uma forma de repetição na qual os elementos essenciais são reproduzidos independentemente do entorno (Malvezzi, 2009, anotações verbais), deduz-se daí um estreitamento de possibilidades incompatível com a criatividade.

É pela contraposição ou pela transcendência com relação àquilo que é convencional, estereotipado, repetido ou rígido que se evidencia a criatividade. Nas palavras de Boden (1999), “A criação será sempre confrontada com o sistema gerativo subjacente àquele domínio, definidor de uma gama de possibilidades”. É a partir da noção de espaço conceitual - composto pelos princípios organizadores que unificam e dão estrutura a um dado domínio do pensamento - que se pode definir a criatividade. A criação será sempre confrontada com o sistema gerativo subjacente àquele domínio, definidor de uma gama de possibilidades. $\mathrm{O}$ exemplo utilizado pela autora para explicar esta questão é da música ocidental pós-renascentista com seu sistema tonal que, durante todo o século XIX, teve suas dimensões harmônicas sacudidas para abrir novas possibilidades até que, ao final deste período, uma grande transformação teve lugar: a atonalidade, com Shoenberg. A relação com o ambiente circundante é evidente nesta proposição de Boden, pois, sem ele, não há como definir a ruptura ocorrida. 
Ainda sobre a influência cultural sobre a criatividade, é importante frisar as diferenças interculturais e seus efeitos sobre criatividade. Com a globalização da economia e a internacionalização dos negócios, equipes formadas por pessoas de diferentes países e culturas têm sido vistas como aspecto favorecedor da criatividade. Outros estudos, utilizando-se do referencial de Hofstede, apontam para algumas culturas nacionais mais criativas que outras (Hofstede, 1997). Investigações interculturais sobre a criatividade ainda são escassos na literatura e, portanto, não serão aqui abordados. Vale assinalar, no entanto, um aspecto constatado no estudo empírico realizado para efeito desta tese, a saber, a exposição ou contato com outras culturas como favorecedora da criatividade. No caso estudado, o fato da família de origem ter imigrado para o Brasil propiciou o contato entre a cultura da família e a cultura brasileira e, desde a infância, a pessoa entrevistada atuava como "tradutora" não somente de uma língua a outra, mas também dos aspectos culturais e de valores, o que favoreceu o desenvolvimento da flexibilidade necessária para a criatividade.

\subsubsection{A questão do valor: quanto vale uma idéia?}

Como ficou evidenciado na abordagem psico-social, um estudo sobre criatividade envolve o elemento do valor, pois toda análise das criações é refém de escalas de preferência, dado que os julgamentos dos atos criativos são relacionados à cultura e aos grupos sociais, que podem elogiar, preservar ou promover determinada idéia, em detrimento de outras. A valorização do novo e da originalidade é condicionada a fatores históricos, políticos, econômicos e sócio-culturais. Leonardo da Vinci só teve reconhecimento póstumo de suas idéia e projetos, por exemplo. 
No campo do valor, vale retomar a análise do Gênesis bíblico na língua hebraica no qual, ao longo do relato da criação divina Deus avalia sua própria obra a cada dia da Criação (Vê haia tov ${ }^{12}$ ). Tais palavras podem ser interpretadas a partir da sensação de completação da obra a cada dia e de que tudo se processou conforme Sua Vontade, o que guarda relação com a questão da motivação intrínseca inerente à criatividade humana, segundo autores como Amabile (1998) ou da possibilidade de uma auto-avaliação do gesto criativo.

No universo humano, o valor concerne à subjetividade individual ao passo que a avaliação é intersubjetiva. Em ambos os casos _ valor e avaliação _ há o confronto do produto com um dado critério. Isso explicaria porque algo que é criativo pode não ser reconhecido como tal em seu próprio tempo, como no caso do compositor Antonio Vivaldi, mencionado por Carpeaux (1958), que teve seu repertório descoberto no início do século XX e publicado na segunda metade deste. Inovador e capaz de compor de maneira não convencional para a época, buscava o reconhecimento no público em geral e não na minoria apreciadora da música. O pintor Van Gogh exemplifica a questão do reconhecimento póstumo. São conhecidos seus problemas com relação a constituir família, custear a própria subsistência ou até mesmo manter contactos sociais. Outro aspecto desta questão é que aquilo que não agrada ao poder vigente pode padecer da mesma falta de reconhecimento.

\subsubsection{Tipologias da criatividade}

Uma vez compreendidos os elementos ontológico (a essência), estético (emoção) e psicosocial (o valor), este capítulo é completado com a análise das categorizações atribuídas à criatividade. Delimitar ou categorizar a criatividade é paradoxal, uma vez que, como se

\footnotetext{
${ }^{12}$ VE HAIA TOV poderia ser traduzido como "E foi bom".
} 
disse anteriormente, o gesto criativo requer liberdade. Reconhecendo que, em todos os campos do conhecimento são elaboradas tipologias e taxonomias, entende-se que a análise do processo criativo não se completa sem essas tipologias apresentadas na literatura, pois elas serão relevantes para a análise dos dados empíricos coletados.

Ao falar em tipologias da criatividade, convém lembrar que, além das distinções, mencionadas anteriormente, entre criatividade menor ou maior (com c-minúsculo ou Cmaiúsculo (Gardner, 1996), pessoal ou histórica (Boden, 1999), cotidiana ou eminente (Lubart, 2008), há autores que se aproximam da idéia de Kuhn (1962) para introduzir as noções de criatividade secundária, "que apenas estende um dos conceitos conhecidos em uma nova área de aplicação" e de criatividade primária, "que provoca uma mudança fundamental na [nossa] percepção da realidade" (Ghiselin, 1963, citado por Lubart, 2007). A primeira não impacta o paradigma vigente em determinado campo, ao passo que a segunda representa uma ruptura paradigmática. Entretanto, como lembra Lubart (2007), essa visão estreita a compreensão da criatividade, uma vez que trata como secundária "a imensa maioria das produções criativas" (Lubart, 2007, p. 128).

Uma outra categorização pode ser encontrada em Koestler (1964), que entende o ato criativo a partir do tríptico "humor, descoberta e arte", identificando aí os padrões equivalentes de atividade criativa, a saber, a descoberta de similaridades ocultas e um contínuo de emoções. No humor, a emoção corresponderia à agressão; na ciência, a neutralidade [de emoções] e na arte, a simpatia ou identificação. Se a ciência busca a verdade (verificabilidade, refutabilidade), a arte propõe a beleza (experiência estética) e o humor, o equilíbrio emocional. $\mathrm{O}$ autor lembra que as fronteiras entre estas atividades são artificiais, uma vez que na Renascença o conceito de cidadania incluía ambas [ciência e 
arte]. Também na atualidade, as fronteiras entre ciência, arte e tecnologia têm se revelado mais fluidas, abrindo-se novas áreas de conhecimento e tentativas de integrar não só arte e ciência, mas ciência e religião, com base na transdiciplinariedade (Cetrans, 2009). Conclui o autor que não há propriamente uma tipologia, mas um continuum entre três tipos de atividades, com uma base comum: novas sínteses realizadas pela bissociação de matrizes de pensamento (Koestler, 1964, p. 27).

Uma das primeiras teorias que buscou categorizar a criatividade foi proposta por Kirton e dizia respeito aos estilos de criatividade. Kirton (1976) classificou dois tipos de pessoas criativas $^{13}$, o (a) adaptador (a), que prefere melhorar as coisas dentro das estruturas e fronteiras existentes e o (a) inovador (a), que prefere fazer coisas diferentemente, reestruturando problemas e formas. Para Kirton, estes são dois tipos distintos, préexistentes, estáveis e consistentes de personalidade o que, para Kaufmann (2004) que o critica, revela a não abertura para a análise da flexibilidade na mudança de estratégia ou até da possibilidade de trabalhar com diferentes estratégias ao mesmo tempo em vários níveis da estrutura de um problema.

Kaufmann (2004) estabelece sua contraposição à teoria de Kirton propondo uma distinção entre novidade no estímulo ou na resposta ou entre criatividade proativa e reativa. Se Kirton (1988, pp. 67-68) descreve aqueles que têm preferência pela criatividade adaptativa como corretos, confiáveis, disciplinados, dignos de confiança, apoiando-se na regra da conformidade (estruturas impessoais previamente ajustadas para resolver problemas), pergunta Kaufmann se isso não denota mais apropriadamente a não criatividade ou a contra-criatividade, pois, se o termo criatividade cobre o leque de comportamentos que vai

\footnotetext{
${ }^{13} \mathrm{O}$ capítulo seguinte trata especificamente da pessoa criativa. Aqui, a menção à personalidade criativa é incluída apenas para acompanhar o raciocínio de Kaufmann.
} 
da conformidade paciente (passiva) ao visionário e à quebra engenhosa de paradigmas, a questão é o que a criatividade não é! E, dessa forma, não seria possível sequer definir o que realmente quer dizer novidade (Kaufmann, 2004, p. 156).

Em sentido literal, novidade quer dizer algo que nunca aconteceu antes, o que, no sentido estrito, pode ser associada àquilo que Boden (1994) denominou criatividade histórica ou criatividade - H. Entretanto, tal conceito implica que uma idéia ou um produto completamente novo foi criado e que a criação em questão é de uma magnitude particularmente alta, como nos exemplos de criar um novo gênero na arte, um novo paradigma na pesquisa científica ou uma forma completamente nova de tecnologia. Mas esse conceito não é desejável, pois, segundo Kaufmann, exalta as proporções divinas e também vai contra a idéia de graus de criatividade, idéia esta que, para ele, é significativa e deve ser preservada. Propõe Kaufmann, de forma semelhante a Lubart (2007), um continuum de criatividade, do grau mínimo ao máximo de novo na solução de um problema.

Neste raciocínio, o conceito de criatividade revela sua relação com a novidade e, por isso, ao conceito de inteligência ${ }^{14}$ (p.157). Assim, ao considerar o continuum de novidade, a criatividade ficará no topo dele _ mesmo que aí esteja envolvida uma decisão arbitrária onde termina inteligência e onde começa criatividade _ e a denominação de criatividade ficaria reservada à "novidade radical".

A partir, então, dos requisitos combinados de novidade e inconvencionalismo (p.158), Kaufmann propõe uma outra categorização (p.159), que considera dois tipos de lócus da

\footnotetext{
${ }^{14}$ A distinção entre criatividade e inteligência será apresentada no capítulo IV.
} 
novidade: a) a novidade no componente da operação mental e b) a novidade no conteúdo da tarefa. Assim, a inovação pode estar no estímulo ou na resposta.

Se o indivíduo está diante de uma tarefa nova e se utiliza de uma solução familiar, deduz Kaufmann que se trata da aplicação simples da inteligência. Se este, frente a uma tarefa familiar, desenvolve uma solução nova, trata-se da criatividade proativa, envolvendo a transformação de algo familiar em não familiar. Se a tarefa é nova e a solução é igualmente nova, está-se diante da criatividade reativa, em que um motivador externo solicita ativamente que o indivíduo considere se uma nova solução é requerida. Finalmente, a rotina, envolvendo tarefas familiares e soluções conhecidas, não se enquadraria no conceito de criatividade, para o autor.

Unsworth (2001), por sua vez, afirma que a maioria das pesquisas pressupõe que a criatividade é um constructo unitário, envolvendo idéias novas e úteis, independentemente do tipo de idéias, das razões que levaram à sua produção ou do ponto de partida do processo. E apóia-se em Sternberg (1999b) para considerar que tal tipologia da criatividade está baseada no resultado do processo criativo, e que, ao focar no produto final, dois problemas se apresentam: a) somente idéias que chegam ao fim do processo são estudadas e b) o processo criativo é visto de forma retrospectiva. Logo, para Unsworth, importa estudar qual é o tipo de engajamento dos indivíduos no processo criativo.

Explica, então, que os comportamentos podem ter início via escolha auto-determinada ou serem causados por demandas externas. Na escolha auto-determinada, revela-se a autonomia e as pessoas experienciam a si próprias como iniciadoras de seu 
comportamento $^{15}$, ao passo que, quando as ações causadas por demandas externas, o indivíduo se engaja em um comportamento porque a situação assim o exige.

Ela propõe, então, estabelecer quatro tipos de criatividade, a saber: responsiva, esperada, contributiva e proativa, descritas a seguir:

Responsiva: O indivíduo tem o menor nível de controle sobre suas escolhas na solução de problemas. Trata-se de uma situação corriqueira na organização, em que geralmente se propõe a formação de um grupo especificamente alocado para resolver um determinado problema. A autonomia na escolha das tarefas é limitada e deve-se responder aos problemas apresentados (colocados) em função de motivos exteriores.

Esperada: Há uma expectativa externa para a solução de um dado problema. Na organização, corresponde, por exemplo, ao momento em que foram implementados os círculos de controle de qualidade ou gestão da qualidade total. Pressupõe-se a necessidade de descobrir problemas, mas em função de motivos exteriores.

Contributiva: Nela, o comportamento é auto-determinado e baseado num problema claramente formulado. Exemplo: um (a) empregado (a) que escolhe se engajar na solução criativa de um problema no qual ele (a) não está diretamente envolvido. É uma resposta voluntária a questões abertas específicas, na qual os problemas são apresentados (colocados) em função de motivos internos.

Proativa: Motivada por fatores internos, representa a busca ativa por problemas para resolver ou o processo de descobrir problemas em função de motivos internos.

\footnotetext{
${ }^{15}$ Esta idéia é muito semelhante à de causalidade pessoal (De Charms). Ver capítulo III.
} 
Seja na análise de Kaufmann, seja na de Unsworth, interessa assinalar a similaridade destes conceitos com o empreendedorismo inovador, objeto da pesquisa empírica empreendida para efeito desta tese ${ }^{16}$, pois as iniciativas empreendedoras inovadoras incluem: a) demanda para que problemas abertos sejam formulados pelo indivíduo; b) antes mesmo da sua formulação, um dado problema deve ser identificado, prescrutando o ambiente para encontrá-lo e, c) deve-se definir o problema de tal forma que ele possa ser resolvido. Além disso, para Kaufmann, tanto a criatividade proativa quanto a contributiva envolvem vender a idéia, elemento presente também no processo empreendedor.

Assim, as tipologias propostas por Kaufmann (2004) e Unsworth (2001) comporão o referencial para a análise dos dados empíricos coletados. Vale ressaltar que o parâmetro "tipo de engajamento" utilizado por Unsworth (2001) para classificar a criatividade contributiva e proativa guarda muita semelhança com a ênfase dada por Amabile à questão da motivação intrínseca para a caracterização da criatividade.

\subsection{O que é a criatividade?}

Criatividade divina, humana, pessoal ou histórica, com $\mathrm{C}$ maiúsculo ou minúsculo, cotidiana ou eminente. A todos estes sentidos, deve ser acrescentada a diferença entre sua natureza transcendente e seu sentido imanente, pela via da objetivação que, tipicamente pode ser identificada no teste de Torrance (1970), um dos mais utilizados em diversos países para caracterização da pessoa criativa.

\footnotetext{
${ }^{16}$ Sobre empreendedorismo inovador, veja o capítulo V e, para a pesquisa empírica, veja o capítulo VI.
} 
A diferença entre objetivação e transcendência remete ao entendimento da criatividade para além do produto, noção predominantemente ocidental, pois, como afirma Lubart (2007), este não é o sentido presente nas culturas ocidentais. "O ato criador [...] precisa de matéria e não pode dispensar a realidade do mundo, [mas] ele não pode ser inteiramente determinado pelos materiais presentes no mundo" (Lubart, 2007, p. 210). Existe uma liberdade inerente a todo ato criador autêntico. É uma emanação da liberdade não determinada por elementos externos ao ser humano.

Ainda no campo da relação entre a criatividade humana e a divina, é possível perguntar se a proximidade com o divino poderia explicar a concepção de Platão de que quem cria está em um estado mental diferente do usual e se esse estado mental inabitual poderia ser a causa das associações do ato criativo com a loucura, desmentidas pela Psicanálise, como se verá no capítulo seguinte pelas afirmações de Freud e Fiorini, dentre outros.

\section{Capítulo III}




\section{A pessoa criativa}

Como se discutiu no capítulo anterior, o conceito de criatividade é plural, guardando significados distintos como categoria de análise ou de prática. Dando continuidade no percurso da compreensão deste fenômeno, cabe perguntar agora se a criatividade refere-se à pessoa criativa, ao processo criativo ou ao produto da criatividade. Procede-se, então, à análise desse problema, sabendo não ser possível esgotá-lo, buscando responder se os fatores determinantes aí envolvidos referem-se a condições estruturais ou dinâmicas processuais. Em outras palavras, poder-se-ia afirmar a existência de uma pessoa criativa, com traços ou características peculiares, ou seria mais adequado referir-se a um processo criativo, acionado por fatores tanto internos quanto ambientais?

Além disso, cabe enfrentar um estereótipo típico deste campo de estudos, dado que, tradicionalmente, associa-se a criatividade a identidades bizarras. Artistas são, por vezes, estigmatizados como loucos e cientistas, representados por personagens, como o professor Pardal (Walt Disney) que, trancafiados em seus laboratórios, permanecem apartados do convívio social. A idéia de uma genialidade que torna o indivíduo alheio, solitário e inacessível, por força de excesso de conteúdos mentais que o distanciam dos demais seres humanos permeou o imaginário social e ainda se faz presente, como se esse tipo de "inteligência" fosse incompatível com uma convivência cotidiana saudável. A partir das grandes narrativas da psicologia apresentadas neste capítulo, pretende-se a desconstrução deste pressuposto, pela afirmação da criatividade como expressão da vida saudável, força vital presente em todos os indivíduos, possibilidade de adaptação criativa à realidade, fonte de prazer e de auto-realização. 
Este capítulo tem, portanto, por finalidade contribuir para a compreensão do sujeito do ato criativo, de forma a explorar esse referencial na análise da criatividade no ambiente das organizações e, em especial, do empreendedorismo inovador, objeto dos capítulos seguintes. A literatura é aqui revisada, destacando teorias da psicologia, buscando os principais fatores que constituem e impactam a criatividade individual. Ênfase particular é dada à noção de causalidade pessoal (De Charms, 1968), que ajudará na compreensão dos dados empíricos coletados, analisados no capítulo VI desta tese. Além das grandes narrativas da psicologia, procede-se também a uma revisão histórica do tema, abrangendo marcos históricos como o discurso proferido por Guilford, nos anos 1950, que foi pioneiro na distinção entre criatividade e inteligência, e também os grandes nomes que marcaram este campo, tais como E. P. Torrance, A. F. Osborn, e Teresa Amabile. 


\subsection{As grandes linhas teóricas da psicologia e a criatividade}

Diversas são as linhas teóricas da psicologia que discutem a questão da criatividade humana e, em função disso, fez-se necessária a escolha de autores (as) e respectivas abordagens. Para discutir o ponto de vista cognitivista, foi escolhida a abordagem de Jean Piaget, pois este se preocupou em compreender como é possível a produção do novo no desenvolvimento humano. Na psicanálise, serão analisados cinco autores: Sigmund Freud, Wilhelm Reich, Alexander Lowen, Hector Fiorini e David Winnicott, este último em função de considerar a criatividade central no psiquismo humano e o primeiro, pela centralidade de seu pensamento para a história da psicologia. Wilhelm Reich é aqui incluído por ter analisado especificamente o trabalho criativo, enquanto Alexander Lowen é mencionado em função de explicitar a relação entre criatividade e instinto de vida e Hector Fiorini, mais contemporâneo, por sua contribuição no sentido de valorizar a criatividade como sinal de saúde mental. Na linha de pensamento humanista, optou-se pelo embasamento em análises procedidas por Abraham Maslow, Carl Rogers e Rollo May.

A investigação tem início pela abordagem dos traços de personalidade, incluindo Zibarras et al. (2008) e Kirton (1989), que entendem o fenômeno como estrutural e passa às teorias que o entendem de forma processual, seja na dinâmica psíquica, como na psicanálise, seja no aspecto cognitivo, como em Piaget.

\subsection{Personalidade criativa?}


Riem de mim porque sou diferente. Rio dos outros, pois são todos iguais (Bob

Marley).

"O inovador é tanto mais primitivo quanto mais culto, mais destrutivo e mais construtivo, ocasionalmente mais louco e, entretanto, adamicamente mais são, que a pessoa mediana"

(Barron, 1963, p. 224).

O estereótipo de loucura associado às pessoas criativas, conforme se mencionou acima, pode ter tido origem em Platão quando este afirmava que no momento da criação, o indivíduo perdia o controle de si mesmo, ficando à mercê de forças divinas. Embora esse estereótipo tenha perdurado por muito tempo no domínio da psicologia, ele deu lugar a novas explicações e concepções sobre a pessoa criativa.

Historicamente, muitos (as) autores (as) se utilizaram da teoria dos traços para buscar descrever o "perfil” criativo. Tal tendência foi substituída por pesquisas e estudos que procuram elencar as características marcantes dos indivíduos, sem, contudo, reduzir o processo criativo a elas. Como se viu anteriormente, Amabile (1996) e Gardner (1996) estudaram biografias de pessoas criativas para compreender o fenômeno. Mais recentemente, pesquisas concluíram que características tais como arrogância, manipulação, dramaticidade, excentricidade e a dimensão "indispor-se contra pessoas" são traços de personalidade disfuncionais que podem ter efeito positivo no processo de inovação (Zibarras et al., 2008). Para chegar a esta conclusão, os autores se utilizaram em sua pesquisa, do inventário denominado Innovation Potential Indicator (IPI), que avalia quatro fatores, a saber: 
- Motivação para mudança: motivação intrínseca para mudança, caracterizada por persistência e ambição. Positivamente relacionada à inovação.

- Comportamento desafiador: tendência pessoal a desafiar o ponto de vista de outros. Inclui comportamento tomador de risco e não-conformidade. Positivamente relacionada à inovação.

- Adaptação, definida como atacar problemas de maneira evolucionária e não revolucionária; foco em trabalhar dentro das fronteiras existentes, mais que em novidades. Negativamente relacionada à inovação.

- Consistência de estilos de trabalho: associada à abordagem metódica e sistemática do trabalho e à conformidade às normas organizacionais. Negativamente relacionada à inovação.

Ainda na mesma pesquisa, aplicaram o Hogan Development Survey (HDS), que contém 11 dimensões e descritores, assim elencados:

\begin{tabular}{|l|l|l|}
\hline \multirow{2}{*}{ FATOR } & DIMENSÃO & DESCRIÇÃO DO INDIVÍDUO \\
\hline Mover-se para & Volátil & Inconsistente e sujeito a humores; \\
longe das pessoas & & $\begin{array}{l}\text { entusiástico em relação a novos projetos, } \\
\text { mas desiludido com reveses e }\end{array}$ \\
& & contratempos. \\
\cline { 2 - 3 } & Desconfiado & Cínico, cauteloso, hipersensível a críticas e \\
& questionador das intenções dos outros. \\
\cline { 2 - 3 } & Cuidadoso & Resistente a mudanças e inovações, \\
\hline
\end{tabular}




\begin{tabular}{|c|c|c|}
\hline & & $\begin{array}{l}\text { relutante frente a oportunidades por medo } \\
\text { de ser criticado ou culpado. }\end{array}$ \\
\hline & $\begin{array}{l}\text { Destacado, } \\
\text { isolado }\end{array}$ & $\begin{array}{l}\text { Absorto em si mesmo e reservado, falta de } \\
\text { interesse ou atenção aos sentimentos de } \\
\text { outrem. }\end{array}$ \\
\hline & $\begin{array}{l}\text { Passivo- } \\
\text { agressivo }\end{array}$ & $\begin{array}{l}\text { Autônomo e preocupado com suas próprias } \\
\text { metas, indiferente aos pedidos das pessoas e } \\
\text { irritável quando outros persistem. }\end{array}$ \\
\hline \multirow[t]{4}{*}{ Indispor-se com } & Arrogante & $\begin{array}{l}\text { Extremamente autoconfiante, com } \\
\text { expectativa de ser respeitado. Não desejoso } \\
\text { de admitir erros ou ouvir conselhos. }\end{array}$ \\
\hline & Manipulador & $\begin{array}{l}\text { Charmoso, porém enganoso, parecendo } \\
\text { gostar de assumir riscos e ultrapassar } \\
\text { limites. Descuidado sobre regras e } \\
\text { convenções. }\end{array}$ \\
\hline & Dramático & $\begin{array}{l}\text { Expressivo, dramático, querendo ser } \\
\text { notado. Impulsivo, imprevisível e gregário. }\end{array}$ \\
\hline & Excêntrico & $\begin{array}{l}\text { Age e pensa de forma criativa e inusual, } \\
\text { com insights originais notáveis; mantém-se } \\
\text { à parte de seus colegas mais convencionais. }\end{array}$ \\
\hline $\begin{array}{l}\text { Mover-se em } \\
\text { direção às } \\
\text { pessoas }\end{array}$ & Perfeccionista & $\begin{array}{l}\text { Cuidadoso, preciso, conservador e } \\
\text { meticuloso; crítico sobre a performance } \\
\text { alheia. }\end{array}$ \\
\hline
\end{tabular}




\begin{tabular}{|l|l|l|}
\hline Dependente & $\begin{array}{l}\text { Ansioso por agradar, confiante nos outros } \\
\text { como apoio e não desejoso de ter ações } \\
\end{array}$ & $\begin{array}{l}\text { independentes. } \\
\end{array}$ \\
\hline
\end{tabular}

Analisando os resultados obtidos, os autores identificam uma relação entre inovação e alguns traços da personalidade considerados negativos. Ou seja, os benefícios da inovação teriam o custo de vir acompanhados de um conjunto de traços de personalidade indesejáveis, em especial aqueles agrupados sob a alcunha "mover-se contra as pessoas" ou indispor-se com elas. Embora tal relação não seja direta, é interessante refletir sobre o fato de que esses dados podem ter grande impacto no processo seletivo de pessoas dedicadas à inovação nas organizações. Se, como afirmam Rank et al. (2004), nenhum indivíduo poderia dedicar-se, simultaneamente, à criatividade e à inovação, os resultados da pesquisa de Zibarras et al. (2008) são cruciais para réplicas e aprofundamentos futuros.

Autores como Zibarras et al. (2008) pressupõem condições estruturais de personalidade que estimulam ou produzem a criatividade, entendendo-as como permanentes, regulares no indivíduo. A resposta à pergunta se haveria pessoa criativa, para eles, é positiva, podendo ser identificada a partir dos traços de comportamento mensurados pelos instrumentos que, como os utilizados na pesquisa, são meios de conceber tal estrutura.

\subsection{Adaptadores (as) ou inovadores (as)?}

Desenvolvendo raciocínio semelhante ao apresentado acima, Kirton (1989) estabelece a distinção entre o comportamento adaptador e inovador, associando-os a estilos de solução de problemas, modos distintos de atividade mental que caracterizariam diferentes tipos de 
personalidade humana, enfatizando que esses estilos de operação mental não são sinônimos de competências ou capacidades individuais. Kirton desenvolveu um instrumento para mensurar os estilos de pensamento subjacentes à solução de problemas e à tomada de decisão, assumindo que o binômio adaptação - inovação é uma dimensão do processo cognitivo que independe do contexto.

Segundo o autor, embora a abordagem inovadora seja necessária para a sobrevivência em qualquer tipo de organização, sabe-se que nas organizações em geral e, especialmente nas grandes corporações e naquelas que envolvem grandes orçamentos, a tendência é encorajar a burocracia e a adaptação de forma a minimizar o risco, pois "os objetivos de uma estrutura burocrática são a precisão, a confiabilidade e a eficiência" (Kirton, 1989, p. 7). Espera-se que as pessoas sejam metódicas, prudentes e disciplinadas, o que resulta num grau elevado de conformidade individual à situação, ou seja, valorizam-se indivíduos de personalidade adaptadora.

Quanto aos indivíduos inovadores, que "consciente ou involuntariamente, reconstroem o problema original como parte de sua resolução, [estes], invariavelmente, têm um problema de comunicação" e, frequentemente, recebem, por parte dos outros, uma recepção cética a suas idéias.

Um exemplo histórico é usado por Kirton em seu raciocínio sobre os dois tipos de personalidade: "Na era medieval, observações astronômicas identificavam movimentos estelares em desacordo com os paradigmas prevalente [...]. Duas soluções eram produzidas [a partir disso]. A primeira retinha a integridade do paradigma e inventava epiciclos de complexidade crescente para enquadrar as observações na teoria. A segunda quebrava com 
a teoria geocêntrica convencional ao colocar o sol no centro do universo" (Kirton, 1989, p. 10). Para ele, não importa que uma delas mostrou-se correta e a outra, não, pois ambas as formas de pensar eram brilhantes; ambas eram boas formas de pensar, mas a teoria heliocêntrica era nova.

O quadro apresentado a seguir explica as características dos dois tipos de personalidade, segundo o autor:

\section{$\underline{\text { Pessoas adaptadoras }}$}

Caracterizam-se pela confiabilidade Parecem indisciplinadas, pensativas, precisa, eficiência, metodicidade, tangenciais, aproximando-se das tarefas prudência, disciplina, conformidade. por ângulos insuspeitados.

Preocupadas com problemas residuais Buscam problemas e rotas alternativas de desencadeados pelos paradigmas atuais. solução, indo além dos paradigmas atuais.

Buscam soluções para problemas em Questionam simultaneamente o problema formas testadas e compreendidas.

\section{Pessoas inovadoras}


Confiáveis em encontrar meios para Ao perseguir suas metas, tratam os meios atingir resultados. aceitos com pouco caso.

Parecem impermeáveis ao tédio, parecem Capazes de trabalho rotineiro detalhado capazes de manter alta precisão em longas (manutenção de sistemas) por apenas jornadas de trabalho. curtos períodos.

São autoridades dentro das estruturas Tendem a ter controle em situações nãoexistentes. estruturadas.

Desafiam as regras raramente, com Normalmente mudam as regras; têm cautela, quando asseguradas por forte pouco respeito pelos costumes passados. apoio.

Tendem a ter elevada dúvida sobre si Parecem ter pouca dúvida de si mesmas mesmas. Reagem à crítica com ao gerar idéias, não precisando de aproximação maior à conformidade. consenso para manter a certeza em face da Vulneráveis à pressão social e à oposição. autoridade; complacentes.

Essenciais para o funcionamento da Numa instituição, é ideal em situações de instituição todo o tempo, mas crises não previstas, e também para ajudar ocasionalmente precisam "dar um tempo" a evitá-las, casos elas possam ser do sistema. controladas.

\section{Quando em situação de colaboracão} com pessoas inovadoras
Quando em situacão de colaboração com pessoas adaptadoras

Fornecem as orientações de tarefa; quebram com o passado e com a teoria 
continuidade na parceria.

São sensíveis a pessoas, mantém o grupo coeso e cooperativo.

Fornecem uma base segura para as Fornecem a dinâmica para trazer à tona operações de risco das pessoas mudança radical periódica sem as quais as inovadoras. aceita.

Parecem insensíveis às pessoas, normalmente ameaçando a coesão e cooperação do grupo.

instituições tendem a se ossificar.

Como se viu anteriormente no capítulo II, as proposições de Kirton são questionadas por Kaufmann (2004) que as considera excessivamente abrangentes, incluindo as pessoas adaptadoras (que são conformistas), no continuum entre o que é criativo e o que não é, contribuindo, assim, muito pouco para a compreensão do fenômeno criativo.

Pode-se dizer que a abordagem de Kirton é tipicamente instrumental, ignorando muitos aspectos da discussão do conceito, com contribuição limitada para a compreensão da pessoa criativa.

Se, de forma geral, nos estudos acerca da personalidade criativa, constata-se a não conformidade ao ambiente, uma espécie de rebeldia com relação aos parâmetros estabelecidos e a dificuldade de aceitação de regras e imposições, seria possível perguntar se a criatividade se refere à personalidade criativa ou a um ambiente favorecedor ou a ambas as hipóteses. As abordagens psicananílicas e cognitivistas serão tratadas a seguir.

\subsubsection{Hector Fiorini: a saúde mental e a criatividade}


"A escultura está no interior da pedra. Resta apenas tirar o que sobra"

(Michelangelo, In; Fiorini, 2004, p. 197).

Assim como os (as) autores (as) da psicologia positiva, Fiorini (2004) identifica, nas tendências e ênfases da psicologia, a preponderância de um olhar psicopatológico e um certo "descuido" (p.177) com relação às propensões "à saúde, ao crescimento, ao desenvolvimento, à mudança, a produções e à aquisição de novas capacidades e de novos elementos de identidade" (p. 177). Baseado nisso, define criatividade como a "mobilização produtiva de um sistema de dinamismos psíquicos que empurram [o indivíduo] na direção destas forças" (p. 178) e pensa a criatividade como um sistema de pulsões e funções psíquicas com traços distintivos próprios, não necessariamente derivados dos outros sistemas, como nas formulações freudianas referentes aos princípios do prazer e da realidade (p. 179). A criatividade seria, para ele, um terceiro princípio organizador ${ }^{17}$ das funções psíquicas, consistindo num "modo de elaborar combinações particulares de processos primários e secundários, [gerando] produções criativas” (p. 193).

A idéia de um processo terciário encontra ressonância com as proposições de Winnicott relativas ao espaço transacional, uma vez, para este, "nos fenômenos transicionais entrelaça-se um mundo de experiências internas com outro mundo de experiências de relações com objetos exteriores e, no enlace desses mundos emerge uma terceira zona, a chamada zona intermediária de experiência" (Winnicott, 1991, citado por Fiorini, 2004, p. 193). E, se os fenômenos criativos emergem no encontro ou intersecção entre diferentes

\footnotetext{
${ }^{17}$ Fiorini baseia sua análise nos dois princípios da psicanálise, a saber, o princípio do prazer e o princípio da realidade e afirma que a criatividade constitui um terceiro princípio. Segundo outros autores de abordagem psicanalítica, o ideal do ego traria à tona um terceiro princípio, o da perfeição. Não cabe aqui a discussão deste tópico. Optou-se por acompanhar o raciocínio de Fiorini, sem entrar no mérito dessa discussão.
} 
ordens de processos, eles acionam um sistema capaz de produzir estes efeitos a partir da construção "entre" mundos diversos, envolvendo estruturas que os compreendem e que remodelam as relações entre os elementos (Fiorini, 2004, p. 194). A produção criativa emerge numa zona intermediária entre os processos internos da pessoa e a relação com objetos externos a ela. "São fenômenos que emergem no encontro, na intersecção de diferentes ordens de processos" (p. 194).

A partir destes pressupostos, Fiorini introduz seus conceitos de objeto e sujeito da criatividade. "O objeto da criatividade é o transformável de todo objeto, isto é, de qualquer objeto ou conjunto de objetos, quando se aplica a ele um trabalho de modificações reestruturantes individuais ou grupais" (p. 195). E acrescenta: "os objetos da criatividade não são coisas, são símbolos". Ao aludir a todo objeto, inclui objetos físicos, mentais, culturais e mesmo condutas ou representações, uma vez que o processo criativo depende apenas de que o sujeito da criatividade localize que "ali há algo transformável por vias imprevisíveis" (p. 196).

O que entender por transformável passa a ser a questão. Do ponto de vista do conceito de criatividade, a transformação tem aqui o sentido de combinação de elementos em que não se reconhece mais cada um deles, discutido no capítulo anterior, envolvendo uma pessoa, um produto e uma ação transformadora. Nessa “condição de transformabilidade (plasticidade de relações, formas e conteúdos), [um] objeto pertence a uma ordem especial de realidade diferente daquela em que se instalam os objetos convencionalmente atribuídos ao mundo real" (p. 196). Logo, "o objeto da criatividade se define por essa mobilidade potencial", o que torna interessante contrastá-lo com a noção freudiana de fixação, pertencente ao mundo do reprimido para a psicanálise. Além disso, o objeto da 
criação é algo a ser extraído das coisas, não é algo projetado nelas. Michelangelo dizia: "A escultura está no interior da pedra. Resta apenas tirar o que sobra" (mencionado por Fiorini, p. 197).

Além de aludir à saúde e não à patologia, o raciocínio de Fiorini remete aos processos criativos desencadeados por pulsões psíquicas e dirigidos à realização, à construção, ao crescimento e ao desenvolvimento humano (p. 178).

Quanto ao sujeito da criatividade, o autor o associa a um conjunto de funções que configuram capacidades transformadoras, tais como registrar, confrontar, avaliar, elaborar, indagar, funções egóicas envolvidas na capacidade de suportar incerteza, frustração, tolerar certa quantidade de angústia, exercendo o controle dos impulsos. Essas capacidades regulam séries de equilíbrios e movimentos como desorganizar e reorganizar objetos; regressões e progressões; análise e síntese, criar desordem e ordem, instalar um caos ou organizar um cosmos. Nesses movimentos, desenvolvem-se processos de aprendizagem voltados a transformar e produzir (p. 197). Ressalte-se que, para Fiorini, o sujeito não é a pessoa, da mesma forma que para Archer (2000), para quem a pessoa é espaço que a diferencia de outros seres e do ambiente circundante. "Essa não coincidência entre o sujeito criador e a pessoa fez com que tantas vezes os movimentos próprios dos processos criativos [sejam] vividos pelo indivíduo com estranheza, aflição, impotência ante a relação com algo de si não abarcável, não governável”' (Fiorini, 2004, p. 198).

Fiorini também entende que é na interação sujeito - objeto do processo criativo que são engendradas as fases de exploração, transformação, culminação e desprendimento. $\mathrm{Na}$ primeira fase, "o sujeito e o objeto da criatividade ainda não se encontraram"; de modo 
potencial, "um está em busca e outro, à espera". As operações exploratórias visam determinar a potencial transformabilidade dos objetos. $\mathrm{O}$ psiquismo não emite muitos sinais desse momento e, por vezes, a consciência do indivíduo pode estar ocupada com outras coisas. Analisando um texto de Marcel Proust, o autor identifica no processo exploratório relações sujeito-objeto tais como atual - passado, interno - externo, conhecido - desconhecido, vivido - imaginado, possível - impossível, concretude desvanecimento.

A fase de transformações é a fase, propriamente, de elaborações criativas, pois o conjunto de funções psíquicas - o sujeito - passa a ser aplicado ao transformável de um objeto, desestruturando-o e reestruturando-o muitas vezes, por meio de duas dinâmicas psíquicas, a dispersão e a seleção. Como resultado desta fase, tem-se o objeto modificado, mas, emerge também um sujeito transformado pelas transformações que operou no objeto. Momento de encontro entre objeto e sujeito transformados, é denominado por Fiorini de fase de culminação, realização, uma experiência de plenitude e harmonização.

Esta fase ou momento é, no entanto, seguida pala etapa de separações, em que o sujeito da criatividade deve se despreender do objeto criado, envolvendo, portanto, perdas e processos de luto. O desapego necessário poderia, inclusive, ser a causa da experiência de solidão dos indivíduos comprometidos em pesquisas criativas ou do estranhamento ao ver a sua produção criativa apropriada por outros meios, veículos ou pessoas ${ }^{18}$.

A identificação das fases do processo criativo leva Fiorini à formulação da lei do movimento, que ele contrapõe à repetição compulsiva, identificada pela psicanálise como

\footnotetext{
${ }^{18}$ No capítulo VI, em que se descreve a pesquisa empírica, encontra-se referência a este estranhamento no relato de um dos sujeitos.
} 
base dos processos neuróticos. A repetição é antagônica à lei deste sistema - o terceiro modo de funcionamento psíquico, a transformação. Conclui o autor (Fiorini, 2004) que no sistema particular responsável pela criatividade humana, o princípio básico é o movimento, a transformação.

Em obra anterior, Fiorini (1995) afirma a existência de um impulso criador que, no psiquismo, luta permanentemente contra a "ameaça capturante" das formas já estabelecidas. Sintetiza os processos psíquicos na criatividade ao alertar para o fato de que explorar os limites do desconhecido ou ultrapassar aquilo que está cristalizado em estereótipos sociais pode produzir ansiedade ou prazer. O prazer se dá pela experiência de libertação que supõe o novo e a angústia surge pelo contato com o caos ou o vazio. A tensão que se produz no interior do psiquismo é a própria dinâmica criativa (Fiorini, 1995).

Em resposta à pergunta sobre a existência de pessoas criativas, Fiorini entende que há uma condição estrutural que modula os processos criativos.

\subsubsection{Winnicott: o brincar e o criar}

Para Winnicott (1975), a análise do acontecimento criador deve se apoiar em um tripé e, portanto, considerar três aspectos-chave: o potencial criador, a experiência criativa e as condições afetivas que favorecem a ocorrência do acontecimento - o "clima" (Kamoto, 2000). Potencial inato ao ser humano, a criatividade é associada à "abordagem do indivíduo à realidade externa" e impacta o desenvolvimento humano tanto na estruturação da personalidade quanto no estabelecimento de uma relação "verdadeira" com o mundo, 
isto é, uma relação pautada pelos parâmetros da realidade. A experiência criativa é "uma forma básica de viver" (Kamoto, 2000) e pode ser compreendida a partir dos conceitos de objeto transacional e espaço potencial (Winnicott, 1975).

O espaço potencial refere-se a uma área intermediária de experiência, situada entre a realidade interna e externa, na qual participam tanto uma quanto a outra; ele está fora do indivíduo, mas não é o mundo externo. Em continuidade direta com a área do brincar da criança pequena, nele tem lugar tanto o brincar da criança quanto, no ser adulto, as artes, a religião, o viver imaginativo e o trabalho científico criador, ou seja, a cultura.

Quanto ao conceito de objeto transacional, Winnicott ensina que estes recebem esta denominação porque correspondem “à transição de um estado em que o bebê está fundido com a mãe para outro em que está em relação com algo externo e separado" (Kamoto, 2000, p. 78). O objeto transicional "guarda consigo a possibilidade concreta de ser o 'nãoeu' ao mesmo tempo em que verdadeiramente representa o 'eu'" (op. citada, p. 79). Para Winnicott, existe uma evolução direta dos fenômenos transicionais para o brincar, do brincar para o brincar compartilhado e deste, para as experiências culturais.

As bases teóricas encontradas em Winnicott serão fundamentais para a identificação de algumas lacunas existentes na literatura especializada no campo da inovação. Segundo Styhre (2008), há poucas referências aos aspectos psico-sociais e motivacionais, além do fato de que a serendipidade e o acaso são abordados como aspectos marginais, embora eles devessem receber a mesma importância que a pesquisa sobre a morfologia da inovação (grifos do autor), com seus pontos de decisão e suas estruturas e modelos formais (p. 136). Este autor realça a importância do fator lúdico e aborda o brincar no processo de inovação, 
contribuindo, assim, para ampliar a compreensão das relações entre criatividade e inovação, tema que será melhor explorado adiante.

A resposta de Winnicott à questão sobre a existência de pessoas criativas é de que a criatividade se deve aos processos da dinâmica psíquica.

\subsubsection{Freud: inconsciente, associação livre, chiste, sublimação}

Para a psicanálise, processos de pensamento que ocorrem nos níveis inconscientes contribuem para a criatividade. Nesse contexto, merecem igual destaque a fantasia e a imaginação. Ao referir-se ao trabalho do [a] escritor [a], Freud entende que, "da mesma maneira que a criança durante o jogo comporta-se como um [a] escritor [a] criativo [a], produzindo um mundo imaginário, rearranjando os elementos deste mundo de uma nova maneira, o [a] escritor [a] criativo [a] [adulto] [a] comporta-se de forma semelhante, discriminando, porém, os elementos da realidade do universo da fantasia”. (Freud, 1908 / 1976). Mesmo que o jogo vá se tornando menos freqüente, a Psicanálise identifica a manutenção da presença, ao longo de toda a vida, da fantasia e do sonhar acordado. Estes elementos, derivados de desejos não satisfeitos, manifestam-se em chistes e sonhos, dentre outros. A frustração na busca da gratidão sexual seria, então, o motor para a realização destes no plano da fantasia, abrindo espaço, assim, para a criação, entendida como sublimação. E, da mesma forma que a sublimação possibilitaria, no plano individual, a satisfação substitutiva dos impulsos sexuais primários, no plano coletivo ela seria o motor do avanço da civilização, pois permitiria o avanço científico e tecnológico, artístico e ideológico. 
Outros autores de linha psicanalítica, como Kubie (1976, In: Alencar, 1993) acreditam que é o processo de associação livre que está na base da criatividade, pois este "liberta o sistema pré-consciente da rigidez imposta ao nível consciente".

É importante frisar que é na própria psicanálise que se encontram as contraposições à noção popular de que a criatividade está associada à loucura. A tal respeito, Freud afirma em "Um estudo autobiográfico" que "O artista, como o neurótico, se afastará de uma realidade insatisfatória para este mundo da imaginação; mas, diferentemente do neurótico, o artista sabe encontrar o caminho de volta daquela e mais uma vez conseguir um firme apoio na realidade. Suas criações, obras de arte, eram satisfações imaginárias de desejos inconsciente, da mesma forma que os sonhos [...]. Mas diferiam dos produtos a-sociais, narcísicos, do sonhar, na medida em que eram calculados para despertar interesse compreensivo em outras pessoas e eram capazes de evocar e satisfazer aos mesmos impulsos inconscientes repletos de desejos também nelas" (Freud, 1908 / 1976, p. 79).

Ou seja, Freud reconhece que ambos os processos - criativo e neurótico - contém elementos inconscientes, mas a vida criativa revela um equilíbrio entre o consciente e o inconsciente, podendo o criador trazer do inconsciente os elementos que serão utilizados, de forma consciente, na criação. Além disso, cabe notar que, ao associar a criação à imaginação, a análise freudiana se assemelha à de Osborn (1965), que a entende como imaginação aplicada.

Para Freud, não há propriamente a caracterização de uma pessoa criativa, mas a identificação de dinâmicas psíquicas processuais que determinam a criatividade. 
Dois outros autores de origem psicanalítica, Alexander Lowen (1984) e Wilhelm Reich (1974), serão apresentados a seguir. Ambos associam a criatividade ao instinto de vida, à energia vital e ao crescimento humano, contrapondo-a à noção de entropia e ao instinto de morte.

\subsubsection{Wilhelm Reich e o trabalho criativo. Alexander Lowen, o prazer e a criatividade}

Reich (1977) faz menção à criatividade quando distingue o trabalho criativo do trabalho reativo. Para ele, somente o trabalho criativo é fator de satisfação, uma vez que nele a energia biológica oscila livremente entre o trabalho e a atividade sexual; estas não se opõem, ou seja, o trabalho não serve à repressão da necessidade sexual, nem há tampouco fantasias sexuais que interferem no trabalho, pois o trabalho e a sexualidade se completam sobre a base de uma sólida auto-confiança. $\mathrm{O}$ interesse se concentra plenamente e sem conflitos, tanto no trabalho como na atividade sexual, impulsionado pelo sentimento de potência e pela capacidade de entregar-se. Opõe-se a ele o trabalho reativo, em que a realização é mecânica, forçada e carente de vitalidade, tendo como propósito reprimir a necessidade sexual e encontrando-se em conflito intenso com a mesma; apenas pequenas quantidades de energia podem ser descarregadas no interesse pelo trabalho propriamente dito e este é essencialmente desprazeiroso. As fantasias sexuais são intensas e interferem na atividade produtiva; têm, então, que ser reprimidas e, assim, criam mecanismos neuróticos que, por sua vez, diminuem ainda mais a capacidade de trabalho. A diminuição desse rendimento, por sua vez, carrega os impulsos sexuais de sentimentos de culpa, diminuindo a autoconfiança e isso conduz, por mecanismo de compensação, a fantasias neuróticas de grandeza. 
A contribuição de Reich também se estende à hipótese da possibilidade de um equilíbrio global do ser humano quando afirma que "O amor, o trabalho e o conhecimento são as fontes de nossa vida. Deveriam, também, governá-la". ${ }^{19}$

Lowen (1984) complementa a visão de Reich ao introduzir a noção de prazer intrínseco associado à criatividade. "Sempre há um elemento de diversão no processo criativo, pois [este] começa com um faz-de-conta, isto é, uma suspensão da percepção da realidade para que o novo e o inesperado apareçam” (Lowen, 1984, p. 15).

O autor ressalta o papel da imaginação na construção da subjetividade humana, possibilitando ao indivíduo ficar momentaneamente livre de pressões e responsabilidades e "transformar a realidade num conto-de-fadas com oportunidades ilimitadas para a autoexpressão e o prazer" (p. 15).

Para Lowen, “o prazer e a criatividade estão relacionados dialeticamente. Sem prazer, não há criatividade e, na ausência de uma atitude criativa diante da vida, não há prazer. Essa dialética surge do fato de ambos serem aspectos positivos da vida. A pessoa viva é sensível e criativa” (p. 27). Lowen estabelece a relação entre a criatividade e o instinto de vida, em contraposição à rigidez caracterológica.

\footnotetext{
${ }^{19}$ A afirmação é encontrada na obra "A Função do Orgasmo", cuja primeira edição foi publicada em 1942. Vale ressaltar uma controvérsia quanto à tradução da frase em questão, pois na edição de 1945 da "A Revolução Sexual", do mesmo autor, encontramos a frase: "Amor, trabalho e saber são as fontes de nossa existência. Deverão também regê-la”. (A Revolução Sexual, Zahar Editores, RJ, 1977). A diferença semântica entre as duas versões ao português é sensível, uma vez que o futuro do presente indica ação futura e o futuro do pretérito indica ação que poderá não se efetivar no tempo futuro, pois depende de algo no passado ou no presente que condiciona sua realização. Como não se teve acesso à versão alemã do texto, utilizou-se a tradução mencionada acima.
} 
Para Reich e Lowen, a pessoa criativa é produto de estruturas e processos que viabilizam a ação institntual. A diferença entre a abordagem de Freud e de Reich é que este último autor leva em conta a influência do contexto sócio-político em que está inserido o indivíduo e o impacto do ambiente na modulação dessas estruturas e processos psíquicos.

\subsection{A visão cognitivista: Piaget e a inteligência reflexiva}

Para Piaget (2001), a criatividade está associada à abstração reflexiva. Teórico da inteligência, o autor destaca que esta não é uma cópia da realidade, uma vez que não está representada nos objetos: é uma construção do sujeito que enriquece os objetos externos. Desta forma, introduz o conceito de criatividade como a capacidade humana de refletir $\underline{\mathbf{o}}$ objeto e refletir sobre o objeto.

Em seu estudo sobre o possível e o necessário, sugere também que “o possível cognitivo é, essencialmente, invenção e criação" (1985, p. 8). Para ele, todo indivíduo encontra-se de posse de dois grandes sistemas cognitivos, aliás, complementares: o sistema presentativo fechado, de esquemas e estruturas estáveis, que serve essencialmente para "compreender" o real, e o sistema de procedimento, em mobilidade contínua, que serve para "ter êxito", para satisfazer necessidades através de invenções ou transferências de processos. [...] O

primeiro desses sistemas caracteriza o sujeito "epistêmico", enquanto o segundo é relativo ao sujeito psicológico. Refere-se às "necessidades" como característica de sujeitos individuais e das lacunas que eles podem experimentar momentaneamente, diferindo da incompletude descoberta em uma estrutura quando de sua tematização. Em contrapartida, a atualização de todo possível conduz a um esquema presentativo, uma vez concluída a 
utilização dos esquemas de procedimento que a ele conduziram; daí a complementaridade dos sistemas (p. 9).

Nessa análise dos possíveis e necessários com relação ao real, diz ainda que "para interpretar a gênese dos possíveis, é preciso assinalar o papel das limitações das quais o sujeito deve libertar-se, que se prendem a uma indiferenciação inicial entre o real, o possível e o necessário. Todo objeto ou matéria de esquema presentativo aparece inicialmente ao sujeito, não apenas como sendo o que é, mas ainda como devendo necessariamente assim ser, o que exclui a possibilidade de variações ou mudanças. Essas "pseudonecessidades" ou "pseudo-impossibilidades" não são [...] particulares das crianças pois as encontramos em todas as etapas da história das ciências". Disso resulta que, para atingir novos possíveis, não é suficiente imaginar processos que visem a um objetivo qualquer (com otimização ou redução a uma busca de variações), pois resta compensar essa forma efetiva ou virtual de perturbação que é a resistência do real quando concebido como "pseudonecessário" (p. 10). Note-se que também a resiliência, anteriormente estudada (Barlach, 2005), envolve superar-se para além dos limites, que podem ser pseudolimites ou limites imaginários.

As relações entre o possível e o necessário são complexas e a evolução do necessário parece paralela à do possível. De um modo geral, pode-se imaginar uma grande lei de evolução englobando o real, o possível e o necessário, [...], com três períodos em suas relações, a saber: 1) indiferenciação: o real acompanha-se, nesse caso, de múltiplas "pseudonecessidades", enquanto o possível se reduz aos prolongamentos diretos do real atual; 2) diferenciação (coincide com formação de agrupamentos e suas operações concretas) das três modalidades: o possível se desdobraria em famílias de co-possíveis; o 
necessário ultrapassaria as coordenações locais, gerando as composições operatórias, condição das formas necessárias, e o real consistiria em conteúdos concretos; 3) integração das três modalidades em um sistema total de modo que o real aparece ao sujeito como um conjunto de atualizações entre os possíveis. Mas o real é, por outro lado, subrdinado aos sistemas de ligações necessárias (Piaget, 1985, p. 8).

Em síntese, em Piaget encontram-se dois aspectos centrais para o estudo da criatividade, a saber: a) o reconhecimento de que a inteligência e a criatividade não são cópias da realidade, uma vez que nem a inteligência nem a criatividade estão representadas nos objetos: são construções do sujeito que enriquecem os objetos externos e, simultaneamente, produzem o sujeito psicológico e b) a proposição de uma lei da evolução englobando o real, o possível e o necessário, em que o estágio de indiferenciação entre os três elementos é progressivamente substituído pela diferenciação e integração, por meio da superação de pseudonecessidades e pseudoimpossibilidades. Ao construir a realidade e, para Piaget, esse é um dado invariante, uma vez que não existe uma realidade em si - o sujeito psicológico é sempre e necessariamente, criativo.

Ayman Nolley se utiliza do princípio do equilíbrio piagetiano para explicar o processo subjacente a todos os tipos de criatividade. "Nesse enquadre, uma conduta criativa será adaptada a um público; ou esse [público] a assimila a uma representação existente ou [...] se acomoda formulando uma nova representação" (Nolley, 1999 In: Lubart, 2007, p. 127).

Embora Piaget não responda propriamente à questão da existência ou não da pessoa criativa para ele há dinâmicas cognitivas processuais passíveis de serem acionadas que garantem a existência da criatividade individual. 


\subsection{A psicologia humanista e a elaboração individual}

O movimento da psicologia humanista, encabeçado por Carl Rogers, Rollo May e A. H. Maslow, afirmava o potencial humano para o desenvolvimento e para a auto-realização.

Rogers (1959), que elabora sua teoria apoiado em sua experiência clínica como terapeuta, define o processo criativo como a emergência de um novo produto relacional que surge da singularidade do indivíduo, por um lado, e dos materiais, acontecimentos ou circunstâncias de sua vida, por outro. Segundo ele, as condições que facilitariam a criatividade construtiva seriam as mesmas que estariam presentes em uma relação terapêutica bem sucedida, ou seja,

- Segurança psicológica: a) aceitação do valor incondicional do indivíduo; b) clima de avaliação externa ausente e c) compreensão empática; e

- Liberdade psicológica: permissão de expressão simbólica, favorecedora de abertura e jogo espontâneo de percepções, conceitos e significados.

Abraham Maslow, outro representante desta tendência teórica, discute a relação entre a criatividade e a saúde mental. Para ele, embora alguns dos maiores talentos da humanidade não fossem pessoas sadias (o autor cita os casos de Wagner, Van Gogh, dentre outros), pessoas criativas podem ser positivamente sadias, altamente evoluídas e amadurecidas, dotadas de capacidade de individuação. Os sujeitos estudados por Maslow (1967, p. 167) não eram poetas, intelectuais ou inventores, mas eram criativos no cotidiano. Maslow afirma que a criatividade normalmente é pensada em termos de produtos, mas deveria incluir pessoas, atividades, processos e atitudes. Para ele, nem todo pintor, poeta ou 
compositor é criativo. Isso não é uma prerrogativa de algum tipo de profissional. Dentre os sujeitos estudados por Maslow havia donas de casa e pessoas que não eram proeminentes em seus campos de atuação. Essas pessoas apresentavam um determinado tipo de humor, uma tendência a fazer qualquer coisa criativamente, eram pessoas abertas para a experiência $^{20}$, que não viviam somente no plano mental, mas mostravam-se capazes de estar na experiência. São sujeitos mais espontâneos e expressivos que a média, mais fluentes, com menos bloqueios e autocríticas; para Maslow, "pessoas em pleno funcionamento" (p. 170), sem estereótipos ou clichês. Como todos os sujeitos estudados por ele eram adultos, mas guardavam uma ingenuidade infantil, ele categoriza este componente como uma "segunda ingenuidade" (Maslow, 1967, p. 170). Não ter medo do desconhecido, gostar do que é misterioso ou intrigante, não ter apego àquilo que é familiar ou necessidade doentia de segurança são, para Maslow, características complementares das pessoas criativas.

Todos nascem com o potencial criativo assim descrito, mas este pode ser inibido quando a pessoa é enculturada (p. 171). Ou seja, o processo de adaptação social pode trazer consigo a inibição da vida criativa. Nas palavras do autor: "Ajustar-se bem ao mundo da realidade significa uma divisão da pessoa. Significa que a pessoa volta as costas a muito de si mesma porque é perigoso. Mas [...], assim fazendo, ela também perde muito, visto que essas mesmas profundidades também são a fonte de todas as suas alegrias, de sua capacidade lúdica, de sua capacidade para amar, rir e, mais importante que tudo, [...], de sua capacidade criadora. Ao proteger-se contra o seu inferno íntimo, a pessoa também se separa do céu que tem dentro de si. No caso extremo, [tem-se] a pessoa obsessiva, tensa, rígida, hirta, controlada, cautelosa, que não pode rir nem jogar ou amar, ou ser confiante, infantil ou 'boba'” (p. 174, grifos do autor).

\footnotetext{
${ }^{20}$ Maslow diz emprestar o conceito "abertura para a experiência” de Carl Rogers (p. 169).
} 
Em síntese, a criatividade individualizante sublinha a personalidade e não suas realizações [importa a qualidade expressiva ao invés da qualidade de resolução de problemas ou confecção de produtos (p. 177)]; salienta as qualidades caracteriológicas, como a audácia, a coragem, a liberdade, a espontaneidade, a perspicácia, a integração, a aceitação do eu, mas assinala a influência ambiental; conclui que tudo isso se expressa na vida criadora, na pessoa criativa ou na atitude criadora.

Abraham Maslow cunhou o termo "criatividade auto-realizadora", referindo-se ao potencial humano para a criação e para a auto-realização que, uma vez presentes, corporificariam a saúde mental, a vida produtiva e a flexibilidade no modo de viver ${ }^{21}$. Individuação, atualização de potenciais, realização da missão, conhecimento mais completo e aceitação da própria natureza, todos estes são elementos que caracterizariam a mais elevada motivação humana, a criatividade auto-realizadora. Para ele, pessoas que realizam o potencial criativo podem não ser brilhantes em uma área específica nem necessitam sê-lo, pois o que importa neste processo é "tornar-se aquilo que se é capaz de ser”, em graus crescentes de integração e sinergia interna, pela unificação de aspectos isolados ou mesmo opostos da personalidade e da realidade (Maslow, 1971), pois a base da auto-realização é a motivação para o crescimento e não o medo ou a falta.

Em seus estudos, Maslow identificou características específicas dos indivíduos criativos, mentalmente saudáveis e auto-realizados. Tais indivíduos tendem a não necessitar ou procurar fama, aplauso, popularidade, status, prestígio ou mesmo enormes quantias de dinheiro (Maslow, 1971; Neilson, 2008, manuscrito); tendem, também, a não temer e, por

\footnotetext{
${ }^{21}$ A associação da criatividade à saúde mental e não à doença indica uma transformação na visão dominante até então, fundada em Platão, para quem a pessoa que cria estaria dominada por forças sobrenaturais (mesmo que divinas) e, assim, distante de sua consciência e próxima da insanidade.
} 
vezes, a serem atraídos, pelo mistério, pelos problemas não resolvidos, pelo desconhecido e pelo desafio.

De forma semelhante a David McClelland, Maslow entende a existência de uma motivação de crescimento e a diferencia das necessidades básicas: "Naquilo que diz respeito ao status motivacional, as pessoas sadias satisfizeram suficientemente as suas necessidades básicas de segurança, filiação, amor, respeito e amor-próprio, de modo que são primordialmente motivadas pela tendência para a individuação (definida como o processo de realização de potenciais, capacidades e talentos, como realização plena de missão (ou vocação, destino, apelo), como um conhecimento mais completo e a aceitação da própria natureza intrínseca da pessoa, como uma tendência incessante para a unidade, a integração ou sinergia, dentro da própria pessoa)" (Maslow, 1967, p. 52). Se as "necessidades básicas constituem, essencialmente, déficits no organismo, [...], buracos vazios que devem ser preenchidos de fora por outros seres humanos que não sejam o próprio sujeito" (grifos do autor), o mesmo não ocorre com a tendência ao crescimento, definido como os vários processos que levam a pessoa no sentido de sua individuação.

Segundo David McClelland (McClelland et al.,1953), a motivação para a realização é a base para o comportamento empreendedor, objeto do estudo empírico realizado para efeito desta tese. Ela é suscitada por situações envolvendo padrões de excelência, seja na cultura em que o indivíduo está imerso ou por meio de modelos ou parâmetros dos pais como representantes da cultura. Essa motivação ganha expressão em comportamentos que incluem competição com esses padrões de excelência. Tal competição pode ser do indivíduo consigo próprio ou com algo externo que diga respeito aos padrões de excelência. 
Também em McClelland é importante ressaltar que, com as mudanças no trabalho humano ao longo do último século, o valor do trabalho-dinheiro passa a se sobrepor ao valor intrínseco, característico da fase da artesania e, no empreendedorismo, de forma semelhante ao artesanato, há um valor predominante que está além do dinheiro; o valor intrínseco do trabalho (McClelland, 1961, p. 233).

Maslow e McClelland não respondem à questão da pessoa criativa, mas agregam à sua análise a presença de impulsos que podem ser mobilizados por outras estruturas, sem, contudo, descrever o processo.

\subsection{De Guilford a Amabile: os alicerces teóricos de um campo de conhecimento numa perspectiva histórica}

Para além das grandes narrativas da psicologia, há também a própria história desse campo de conhecimentos. Nesta história, a criatividade é tratada em seu processo, não se referindo aos indivíduos que criam. A maioria dos (as) autores (as) que serão apresentados a seguir não descrevem propriamente a personalidade criativa ou estudam a pessoa criativa, mas apontam os fatores que acionam o processo criativo.

O discurso de J. P. Guilford (1897 - 1987) como presidente da Associação Americana de Psicologia em 1950, mencionado anteriormente, é, certamente, um dos marcos históricos para os estudiosos da criatividade e também um divisor de águas que estabelece uma distinção entre criatividade e inteligência, temas que vinham sendo tratados como um só até então. Guilford introduziu a idéia de que a inteligência deveria ser caracterizada por meio de três dimensões: Conteúdo, Operações e Produções e estabeleceu a diferença entre 
produção convergente e divergente (Guilford, 1950). Estas dimensões foram apresentadas por ele por meio de um modelo cúbico tridimensional que possibilitava compreender a estrutura do intelecto. No modelo, produção convergente e produção divergente são dois dos modos operantes das operações mentais. Esse aspecto foi analisado quando da descrição das etapas do processo criativo que permeiam a distinção entre criatividade e inovação.

No discurso citado, Guilford refere-se ao "espantoso desprezo pela criatividade na educação", sugerindo que os processos didáticos apoiavam-se na idéia de que existem respostas certas para as questões propostas pelos (as) educadores (as) ao invés da proposição de problemas e desafios para que os (as) educandos (as) buscassem soluções para as questões.

De uma forma surpreendentemente atual, Guilford apontava, já em 1950, para a pressão para a conformidade e para a satisfação de padrões em que "as inclinações pessoais não são bem vistas" (p. 447). Para ele, ensinar a pensar implica, necessariamente, em mudanças no processo de ensino e o desenvolvimento da personalidade criativa é assunto altamente individual que enfatiza a unicidade (uniquiness) ao invés da conformidade, não estando a escola preparada para tal.

Vale notar, ainda neste mesmo discurso, a afirmação de que haveria uma certa ingenuidade em pensar que as pessoas criativas são dotadas de certas qualidades que outras não possuem (p. 446). Segundo ele, todos os indivíduos possuem em algum grau todas as habilidades, com exceção de casos patológicos; ou seja, há criatividade em todos os indivíduos, mesmo que esta seja pouco freqüente em alguns. 
Estudos realizados na época com cientistas e inventores constaram que as pessoas criativas são dotadas de: a) sensibilidade a problemas, envolvendo curiosidade e habilidade para formular perguntas; b) fluência, medida pela quantidade de idéias por unidade de tempo; c) novas idéias, caracterizadas pela freqüência de idéias incomuns, mas aceitáveis; d) flexibilidade, ou seja, facilidade para gerenciar mudanças ou o oposto da rigidez; e) capacidade de síntese, ou o oposto da análise; f) formulação de gestalts, pela reorganização e redefinição de totalidades; g) complexidade, capacidade de aceitar confusão; e h) reestruturação avaliativa.

Já nos primórdios dos estudos sobre a criatividade fica claro que "o inventor é aquele que não leva muito a sério a educação" (Kettering, in: Guilford, 1950), confirmando inúmeras biografias de laureados com o prêmio Nobel compiladas por Larsson (2005) e a idéia de que a educação formal pouco tem a ver com a criatividade, possibilitando a hipótese de que indivíduos altamente criativos podem ser até mal avaliados na educação formal, como no caso do cientista Albert Einstein ${ }^{22}$ (Gardner, 1996).

As idéias de Guilford foram seguidas por diversos autores, que, de uma forma ou de outra, acrescentaram elementos ao seu esboço teórico básico. Serão exploradas, a seguir, as proposições de Osborn, Bono, Torrance e Amabile. Embora não incluído nesta tese, Gilles Deleuze também foi estudado em função de sua análise sobre a diferença e a repetição, temas correlatos à criatividade. Note-se que a ordem cronológica foi adotada como critério de exposição.

\footnotetext{
${ }^{22}$ Albert Einstein afirma: “A imaginação é mais importante que o conhecimento" (1994).
} 
Se o discurso de Guilford teve lugar no ano de 1950, logo em seguida ${ }^{23}$ Alex Osborn publicou um livro que até o presente ainda é referência do ponto de vista teórico: "Imaginação aplicada", no qual introduz diversas técnicas para o desenvolvimento da criatividade, dentre elas o brainstorming, técnica largamente utilizada para geração de idéias em grupos, e elabora os passos de um processo que estaria presente na criatividade, a saber, preparação, análise, hipótese, incubação, síntese e verificação. Posteriormente, Osborn reelaborou este processo, propondo um movimento de busca de fatos, problemas, idéias, solução e, finalmente, busca de aceitação.

Para Osborn, todos os seres humanos possuem faculdade imaginativa e, portanto, mais do que buscar desenvolvê-la via exercício, o autor propõe técnicas para fazer uso mais produtivo das faculdades inatas que já se possui. Considera que a imaginação é base da criatividade e que este é o elemento-chave para o empreendedorismo e, consequentemente, para o desenvolvimento econômico e social de uma nação (1965, p. XVII). A análise de Osborn guarda consistência com a de David McClelland (1961) que, tendo estudado as sociedades antigas e modernas, identifica elementos do espírito empreendedor e automotivado na base das sociedades que se desenvolveram satisfatoriamente ${ }^{24}$.

A técnica do brainstorming apresenta, como grande diferencial, a suspensão do julgamento durante a fase de produção de idéias, respeitando a hipótese do autor de que a avaliação das melhores idéias será etapa posterior do processo de criação, sob pena de comprometê-lo com a crítica precoce. A técnica vem sendo amplamente utilizada desde a sua criação e dados do próprio autor revelam que, já em 1965, era possível identificar indústrias que incluíam em seus programas de treinamento de pessoas a educação para o

\footnotetext{
${ }^{23}$ A primeira edição do livro de Osborn foi publicada em 1953.

${ }^{24} \mathrm{O}$ tema do empreendedorismo e sua relação com a criatividade é tratado no capítulo IV.
} 
brainstorming. Em 1967, Osborn foi o fundador da Fundação para a Educação Criativa, entidade cujo objetivo seria capacitar pessoas, grupos e instituições para a solução criativa de problemas.

E. P. Torrance (1915 - 2003), por sua vez, notabilizou-se pelo desenvolvimento de instrumentos de medida da criatividade. $\mathrm{O}$ teste que leva seu nome propõe-se a mensurar o pensamento divergente e outras habilidades de solução de problemas, abrangendo: fluência (numero total de idéias relevantes, interpretáveis e significativas geradas em resposta a um estímulo); flexibilidade (número de diferentes categorias de respostas relevantes); originalidade (raridade estatística de respostas entre os sujeitos do teste) e elaboração (a quantidade de detalhes nas respostas). A visão de Torrance (1974) é semelhante à de Guilford no que se refere à distinção entre inteligência e criatividade. Como crítico dos testes de QI usados até então para mensurar a inteligência, para ele também, embora uma certa quantidade de inteligência seja necessária para a atividade criativa, ela, por si só, não é condição suficiente para seu surgimento.

Edward Bono (1933 - ) cunhou o termo pensamento lateral e a idéia de que é possível “pensar fora da caixa ${ }^{25 "}$. Para o autor, o pensamento lateral guarda relação intrínseca com o insight, a criatividade e o humor. Entende o pensamento lateral como o processo e a criatividade como representante do resultado deste. O pensamento lateral se distingue do pensamento vertical, mas ambos guardam relação de complementariedade. Assim, se o pensamento lateral é generativo, o vertical é seletivo, mas o pensamento lateral pode propiciar efetividade ao vertical, enquanto o vertical pode desenvolver as idéias geradas pelo lateral. Também para este autor, a educação enfatiza quase que exclusivamente o pensamento vertical, em detrimento do lateral, tendo como conseqüência o

\footnotetext{
${ }^{25}$ No inglês, think-outside-the-box.
} 
desenvolvimento - limitado - da mente apenas como sistema memorístico. Um dos elementos mais interessantes neste desenvolvimento teórico é a afirmação de Bono de que o pensamento lateral "busca deliberadamente a informação irrelevante" (p. 12), que se contrapõe à excessiva "objetividade", acompanhada de imediatismo, valorada no momento atual e o aparente desprezo pelo irrelevante, inútil e tudo aquilo que não produza resultados imediatos, práticos e concretos. Esse aspecto será oportunamente abordado quando da análise da criatividade no ambiente das organizações.

Uma compilação das teorias que marcaram a história deste campo do conhecimento encontra-se em Golver et al. (1989). Este manual traz o entendimento da criatividade como variável interveniente, não diretamente observável, e a definição de criatividade como uma categoria do funcionamento mental com uma limitada sobreposição com a inteligência, seja nos processos aí envolvidos, seja quanto às características dos indivíduos que as exibem. A síntese de Golver et al. (1989) incorpora os estudos de Amabile (1996), cuja abordagem psico-social constitui fator de embasamento para teóricos modernos, na qual as influências do indivíduo e do ambiente em que está inserido são entendidas como complementares. Assim, elementos genéticos são tratados como predisposições cujos efeitos se desenvolvem diferentemente em condições ambientais diferentes, interagindo com as condições exteriores de maneira a produzir não um determinado efeito, mas, sim, uma certa “classe de reações". Para a autora, a criatividade é um comportamento resultante de uma constelação de características pessoais, habilidades cognitivas e ambientes sociais (Glover et al., 1989, p. 26). Em Amabile (In: Glover et al., 1989; 1996), encontram-se as referências às habilidades do pensamento divergente (criativo), que incluem a fluência, a flexibilidade, a originalidade, a redefinição e a elaboração, como em Torrance (1979); a criatividade é tratada segundo seus quatro componentes: o processo, o produto, a pessoa e 
a situação (p. 3). A autora enfatiza a relação entre criatividade e motivação intrínseca, aspecto que será de fundamental importância ao abordar a questão da criatividade nas organizações.

De acordo com Amabile (1996), por muitos anos os estudos e pesquisas sobre criatividade procuraram entender as características ou traços de personalidade dos indivíduos criativos. Poucos estudos examinaram os efeitos de ambientes - físicos ou sociais - sobre a produção criativa (p. 5). Destes, segundo a autora, cabe mencionar os que buscaram comparar o efeito de salas de aula tradicionais versus salas abertas (Klein, 1975, citado por Amabile, 1996, p. 5), bem como o estudo de Torrance et al. (1960, citado por Amabile, 1996, p. 5) que buscava analisar a produção criativa em salas de aula de grandes cidades se comparada às salas de aula de pequenas cidades. À exceção desses escassos estudos, os demais tentavam identificar diferenças individuais que pudessem explicar a criatividade, excluindo as situações criativas, atribuindo aos fatores genéticos mais importância que aos ambientais ou à aprendizagem (p. 5). Tendo como base biografias ou autobiografias, tais estudos foram revisitados à luz da abordagem psico-social. De forma semelhante a Gardner (1996), a autora apresenta alguns exemplos dos aspectos ambientais significativos da história de vida de Albert Einstein, Picasso e outros.

Amabile analisa a importância do tipo de escola frequientado por Albert Einstein ao longo de sua infância e juventude. O "estilo independente de estudar", manifesto como característica do grande cientista encontrou terreno fértil para se expressar quando, tendo enfrentado as pressões de uma escola germânica rigorosa, mudou-se com a família da Alemanha para a Suíça e adentrou uma escola de orientação humanista após ter fracassado nos exames de acesso a outra escola. "Essa atmosfera social encaixou-se idealmente com o 
estilo independente de pensar e trabalhar de Einstein" (Amabile, 1996, p. 7). Um contexto liberal sem excessiva autoridade externa foram os aspectos destacados por Amabile na análise deste caso.

Segundo a mesma autora, pessoas criativas tendem a resistir a tentativas externas de controle de seu comportamento. Ela exemplifica com o relato na primeira pessoa do cineasta Woody Allen que afirma gostar de atuar como comediante e escritor, mas tem reservas com relação ao processo de filmagem em função de que outras pessoas detém o poder sobre alguns aspectos deste, não possibilitando a ele o domínio pleno dos resultados. As mesmas questões identificadas por Amabile no caso de Woody Allen foram encontradas em uma das entrevistas realizadas para efeito desta tese, conforme se verá no capítulo VI e também podem ser encontradas em Tschang (2007), na análise de uma indústria criativa ${ }^{26}$.

"Motivação intrínseca conduz à criatividade, ao passo que a motivação extrínseca é detrimental" (p. 15). A contraposição entre os dois tipos de motivação é a base de toda a estrutura de raciocínio da autora. Estar motivado (a) por si mesmo (a) para fazer algum tipo de atividade, pelo prazer da própria atividade, é a conceituação de motivação intrínseca fornecida por Amabile (1996). E, quando a autora afirma que são pessoas concentradas nos aspectos intrinsecamente interessantes de uma tarefa, é possível associar esta idéia ao brincar, como se viu em Winnicott ou aos estudos sobre o elemento lúdico presente na criatividade (Huizinga, 1996; Lewis, 1996; Rothenberg, 1996). Ambientes que encorajam a autonomia e o auto-aprendizado podem fomentar a criatividade, ao passo que os aspectos ambientais desfavoráveis à motivação intrínseca, tais como restrições à escolha de engajamento ou não em uma tarefa, excessiva supervisão do trabalho,

\footnotetext{
${ }^{26}$ Veja capítulo V desta tese.
} 
expectativas quanto à avaliação deste, entre outros, são obstáculos à criatividade. Mas, lembra a autora, estas hipóteses se aplicam somente às tarefas heurísticas, em que não há um caminho claro e linear em direção a uma solução. Efeitos opostos podem ser esperados em relação a tarefas algorítmicas.

Antes de concluir esta revisão histórica, menciona-se o estudo de Rank et al. (2004) que discute os elementos que permitem predizer a produção criativa no ambiente organizacional. Dizem eles que, no que concerne à personalidade, a introversão é preditor da criatividade; extroversão, da inovação, em função da necessidade de persuadir outros stakeholders na organização sobre o valor de suas idéias. $\mathrm{O}$ afeto positivo facilita solução criativa de problemas; o afeto negativo (tal como raiva) facilita inovação em resposta às deficiências frustrantes. Conclusão importante deste estudo é que, se a introversão e a extroversão afetam diferentemente a criatividade e a inovação, poucos (as) empregados (as) poderão dominar os desafios da criatividade e da inovação.

Quanto ao ambiente, os times e organizações são mais propensos a inovar se o ambiente é incerto e ameaçador, enquanto a criatividade exige ambiente não demandante. Para a implementação, vale o oposto. Estressores podem levar à inovação se os empregados se engajarem em coping focado no problema. Urgência do projeto ou competição com outras organizações pode levar à criatividade enquanto outras demandas (alta pressão de tempo ou competição dentro do grupo) são detrimentais.

No aspecto liderança, o autor enfatiza que o carisma é menos condutivo à geração de idéias que à sua implementação, uma vez que os seguidores deste tipo de líder podem 
aderir à visão do líder ao invés de perseguir sua própria idéia, o que restringe a autonomia que é crítica para a criatividade.

Os mesmos autores (Rank et al, 2004) resumem as fases do processo, destacando que os estágios do processo de inovação envolvem a promoção de idéias, o assegurar fundos para implementar estas idéias e o desenvolvimento de schedules para sua implementação. Quanto aos estágios da criatividade, destacam a identificação da tarefa, a preparação, a geração e validação da resposta e a comunicação. Nesse sentido, motivação intrínseca é benéfica para a identificação da tarefa e a geração de respostas, enquanto a motivação extrínseca - suportiva e não controladora - pode facilitar a preparação e sua validação.

Estes autores apontam diferenças entre inovação tecnológica e administrativa e entre a evolutiva e a revolucionária. Também diferenciam tipos de criatividade com motivos internos ou externos e tipos de problemas específicos versus problemas auto-descobertos. Importante frisar os conceitos de pró-atividade, tais como iniciativa pessoal e comportamento verbal, que podem ser cruciais para a tradução de idéias em inovações implementadas.

No aspecto de iniciativa pessoal, comportamentos de auto-início, proatividade e persistência, tais como ir substancialmente além dos conteúdos prescritos pelo trabalho (iniciativa qualitativa), despender energia adicional no trabalho (iniciativa quantitativa) e demonstrar perseverança em face dos problemas (superar barreiras) são cruciais: a iniciativa pode predizer inovação e pode moderar a relação entre criatividade e inovação de forma que idéias são mais provavelmente implementáveis se a iniciativa for alta. $\mathrm{O}$ comportamento auto-iniciado e proativo pode fortalecer a ligação entre criatividade e 
comportamento verbal (comunicação da idéia); a iniciativa pode ainda modificar a relação entre inovação e resultados.

Face às principais tendências atuais de globalização e alta taxa de inovação, entendem os autores que os processos complexos de desenvolvimento de produtos envolvem numerosos (a) engenheiros (a) e outros (as) profissionais alocados (as) ao largo do globo e os valores culturais influenciam criatividade e inovação (Hofstede, 2001, In: Rank et al, 2004), reforçando a importância dos fatores interculturais apresentados no capítulo II da presente tese.

\subsection{Motivação intrínseca ou causalidade pessoal?}

Como mencionado anteriormente, Amabile (1996) identifica na motivação intrínseca o fator decisivo para a manifestação da criatividade pessoal. Maslow e McClelland também abordam questões motivacionais. A discussão se amplia ao considerar a proposição de De Charms (1968) do conceito de causalidade pessoal, assim definido: "Causalidade pessoal é a iniciação, por um indivíduo, de um comportamento com a intenção de produzir uma mudança no seu ambiente" (p.6).

Segundo o autor, o pensamento leigo assume que o ser humano, em circunstâncias normais e dentro de certos limites, escolhe agir do jeito que age. Pergunta-se, por exemplo: Porque uma certa pessoa se comportou deste jeito? O que a levou a escolher fazer isso? Duas são as interpretações utilizadas pelo senso comum: a) assumir que o indivíduo é uma pessoa que controla seu próprio comportamento, ou seja, que o comportamento de uma pessoa é causado; b) assumir que forças físicas controlam o 
comportamento. O problema, segundo De Charms, com a noção leiga, é que ela pode explicar qualquer coisa depois que esta aconteceu dizendo que a "mente" causou o comportamento, mas a mente do indivíduo permanece como um agente imprevisível. Tudo isso remete aos debates prevalentes no século 19 sobre a problemática da relação mente corpo e da noção de causa.

Seria a causalidade pessoal sinônima da motivação? De Charms afirma que, se os seres humanos acreditam ser eles mesmos a "causa" de suas ações e atitudes, esta crença afeta seu comportamento. Mas o conceito de causa supõe que um objeto qualquer seja normalmente estacionário e que alguma fonte de energia externa seja impingida sobre ele. Assume-se que a) o estado normal dos objetos físicos seja o equilíbrio estático; b) a causa da mudança do estado normal seja uma fonte de energia; c) a causa é externa ao objeto no qual é produzida a mudança ou efeito; d) o efeito é movimento; e) a atribuição de causalidade é aprendida; e f) o conceito de causa ajuda a predizer futuros eventos.

Ou seja, segundo De Charms (1968), o problema básico das teorias motivacionais é a suposição de um organismo estático. Contrapondo-se a esta visão, ele assume a pessoa como sujeito, causa pessoal de seu próprio comportamento, que tem intenções e que as carrega dentro das fronteiras de suas limitações físicas (De Charms, 1968, p. 12). O autor afirma a existência e a prevalência do lócus interno de controle.

Em sua análise, De Charms critica a visão de McClelland e outros, que assumiram que os estímulos positivos são buscados e os negativos, evitados sempre que possível pois isso não explicaria, por exemplo, o comportamento de brincar da criança, que pode estar presente mesmo quando condições de fome, dor ou medo intenso também estão. A 
tese de De Charms coloca-se para além da visão hedonista - buscar o prazer e evitar a dor. Diz ele que, se, em Freud, a idéia de princípio do prazer representa um "hedonismo do futuro", os experimentalistas propunham um "hedonismo do passado" (p. 55). Em outras palavras, é a antecipação do afeto que organiza e dirige o comportamento? Haveria um evento identificável que ocorre imediatamente antes do comportamento (evento afetivo antecedente)? (p. 57).

A noção de causa é complexa. Nas palavras do autor: "Dizer que o copo quebrou porque uma pedra o atingiu é bastante diferente de dizer que o copo quebrou quando uma pedra o atingiu porque ele era frágil" (p. 58). Muitas vezes assume-se que um componente do estado motivado de comportamento é o afeto e que é ele que dirige o comportamento. De Charms critica a teoria de McClelland dizendo que este entende o afeto como fator de antecipação do sucesso, perguntando "Como entender o comportamento auto-motivado em situações livres de brincadeira e atividade criativa?" (p. 59 e 60). Tal comportamento não é direcionado pelo estado afetivo prévio ou expectativa de recompensa.

Se o sistema nervoso é um aparato com a função de se livrar dos estímulos que o alcançam ou de reduzi-los ao menor nível possível e, se viável, manter-se na condição de não estimulação, mudar o mundo externo para satisfazer a fonte interna de estímulo (p. 81) é a raiz da causalidade pessoal. Ou seja, a causalidade pessoal refere-se ao comportamento que muda o ambiente e é controlado pelo ator. O indivíduo é lócus da causalidade, a origem do próprio comportamento (p. 328). De Charms conclui que o conhecimento ou sensação de causalidade pessoal é crucial na distinção entre motivação intrínseca e extrínseca. Para efeito de pesquisa, o autor entende que, em função da dificuldade de distinguir os dois tipos de motivação do ponto de vista prático, é necessário conceber 
situações nas quais os dois fatores estejam em oposição. Entretanto, de forma experimental, é mais fácil restringir a liberdade do que expandi-la. Logo, a redução da liberdade de escolha é a técnica mais usada nos experimentos.

Na visão de De Charms, a liberdade de escolha é elemento fundamental para o conceito de causalidade pessoal (De Charms, 1968, p. 337) "Para a pessoa sentir fortemente que ela é a origem de seu próprio comportamento, ela deve também sentir que dependia dela agir de uma ou de outra maneira, identificar a causa do comportamento dentro de si”. Diferencia, então, a sensação de ser a origem do próprio comportamento ou de ser um joguete ou refém do destino, por exemplo (p. 343). Sua hipótese é de que, ao trabalhar como uma “origem", os sujeitos sentiriam mais prazer e mostrariam mais investimento pessoal na tarefa e em suas próprias produções do que ao trabalhar como "refém".

Para o autor, a pessoa tem tendência predominante para um ou outro estado, ou seja, esse aspecto constitui uma característica da personalidade. Assim, a motivação extrínseca configura um comportamento para alcançar recompensa, uma espécie de refém mediador da recompensa, ao passo que a motivação intrínseca revela essa sensação de comportamento-origem; envolve liberdade e auto-investimento.

O conceito de causalidade pessoal será utilizado na discussão dos resultados da pesquisa empírica realizada para efeito desta tese, uma vez que ele ajuda a compreender o comportamento empreendedor como aquele comportamento iniciado pelo indivíduo, com intenção de produzir uma mudança em seu ambiente com objetivo de promover a autorealização. 


\subsection{A psicologia da criatividade}

Para sintetizar os temas presentes na revisão da literatura é necessário reconhecer, antes de tudo, que o conceito de criatividade e o estudo da pessoa criativa é tão complexo que é necessário abranger aspectos abordados por diferentes autores (as) dentre as grandes narrativas da psicologia.

Ao dizer que a criatividade refere-se à produção de idéias novas e potencialmente úteis por um indivíduo ou pequeno grupo de indivíduos trabalhando juntos (Amabile et al., 1996 In: Rank, 2004), é possível entender a organização como espaço privilegiado de pesquisa, pois nela [organização] tem lugar o trabalho individual e coletivo. No entanto, qualquer pesquisa deve considerar outros aspectos relevantes, tais como a associação da criatividade com o trabalho auto-realizador (Reich, 1977) ou à natureza da atividade capaz de suscitar a criatividade. Destacam-se aí os aspectos desafiadores capazes de motivar os indivíduos ou grupo de indivíduos de forma intrínseca. Ou seja, se entendida como solução de problemas, a criatividade deve ser incentivada a partir de projetos desafiadores, capazes de suscitar tal motivação.

O processo de produção de idéias não pode prescindir de um clima propício, passível de propiciar ao (s) indivíduo (s) a segurança psicológica e liberdade de expressão apontada por Rogers (1959). Este clima permitiria a presença do elemento lúdico, no entendimento de Winnicott (1975).

O tipo de inteligência (Piaget, 2001; Augras, 1972) utilizado na resolução criativa de problemas parece guardar relação com o pensamento lateral ou divergente, conceito 
proposto por De Bono (1990) e pode também ser associado à visão da Gestalt sobre "boa forma" (Latner, 2003). A distinção proposta por Piaget entre o necessário e o possível na construção da realidade, aspecto relevante para a caracterização da criatividade.

Em síntese: o desenvolvimento da criatividade implica o exercício da liberdade e do "correr riscos" e a disponibilização de tempo e espaço para a iniciativa pessoal. A consideração de que a criatividade advém do pensamento divergente implica na necessidade de segurança psicológica, pela ausência (ainda que momentânea) de avaliação externa, como na técnica do brainstorming, criada por Osborn (1965).

Com relação ao tempo, cumpre destacar sua importância para qualquer processo voltado ao desenvolvimento criativo. O tempo para criar deve ser visto como um tempo especial, a ser vivenciado e apropriado livremente pelos indivíduos, sem elementos de pressão excessiva. Considerando o aspecto serendipidade, cabe ressaltar que os estímulos oferecidos aos indivíduos podem e devem ser abrangentes, não necessariamente guardando consistência com seu trabalho ou atividade específica, principalmente se considerada a hipótese da Gestalt de que o momento de insight ocorre, na maioria das vezes, quando o (s) indivíduo (s) não está buscando a solução do problema.

A serendipidade, definida como "a capacidade de tirar partido do acaso" (Augras, 1972), implica não só num tempo distinto daquele em que se está procurando a solução para um problema, mas também a possível concentração do indivíduo em assunto diferente daquele em que a questão tem foco. Assim, cultivar ou dedicar-se a temas que não estão diretamente ligados à questão principal pode ser uma importante forma de promover ou facilitar o processo criativo e entender um de seus aspectos centrais, a saber, a necessidade 
de um tempo especial e do cultivo de assuntos aparentemente inúteis - do ponto de vista do problema.

May (1975) explica este processo afirmando que a intuição ocorre no momento de transição entre o trabalho e o repouso (p. 61) ou de relaxamento da tensão (p. 62). Alternar trabalho e descanso pode ser, então, uma importante via de acesso à intuição criativa. Mas, mesmo neste raciocínio, cabe entender o significado de descanso que não necessariamente precisa ser visto como repouso físico, podendo comportar momentos de substituição do foco de atividade.

Entende-se, outrossim, que a criatividade é uma das competências exigidas no trabalho humano atual e é condição da resiliência demandada pelas contingências adversas que as pessoas enfrentam neste contexto (Barlach, 2005).

A síntese das várias propostas passíveis de auxiliar na compreensão do conceito abrange temas como originalidade, flexibilidade (Torrance), uso da fantasia e do imaginário (Freud), capacidade de pensar "fora da caixa" (Bono), saúde mental se contraposta à neurose (Fiorini, Reich, Lowen, Rogers, May, Maslow) e prazer (Lowen).

É também fundamental considerar a noção de causalidade pessoal (De Charms, 1968) e de motivação para a auto-realização (McClelland et al., 1953). A pessoa com elevado grau de necessidade de auto-realização e motivação intrínseca tem a crença sobre o lócus de controle interno que possibilita administrar o ambiente para realizar seus projetos. Como se verá no capítulo $\mathrm{V}$, a força da causalidade pessoal está associada à tendência emancipatória e à paixão empreendedora. 
De todas as análises se deduz que os (as) diferentes autores (as) se impõem à consideração, não havendo uma resposta única ao problema da pessoa criativa, mas, sim, uma resposta plural. 
Capítulo IV 


\section{A necessidade de diferenciação de conceitos}

Na revisão da literatura acerca da criatividade nas organizações e nos negócios, é possível identificar termos correlatos que ora se sobrepõem, ora se confundem, impondo a necessidade de diferenciá-los, tanto em termos conceituais quanto enquanto categorias de análise e de prática. A criatividade encontra-se associada a outros conceitos como inteligência, sabedoria, invenções e descobertas e também como componente humano necessário ao processo de inovação, seja esta tecnológica, organizacional, de produtos, de serviços ou de processos.

As definições existentes na literatura que associam a criatividade ao novo e sua utilidade, como, por exemplo, "a capacidade de realizar uma produção que seja ao mesmo tempo nova e adaptada ao contexto na qual ela se manifesta" (Lubart, 2007) ou "produção de idéias novas e úteis por um indivíduo ou pequeno grupo de indivíduos trabalhando juntos" (Amabile, 1996), dificultam a distinção entre criatividade e inovação e mesmo invenção, temas que guardam estreita associação com aquela, em função do utilitarismo aí presente. Como se viu anteriormente, a criatividade refere-se, sim, ao novo, mas não necessariamente ao útil. Quando imersa num universo utilitarista, a criatividade ganha novos contornos, podendo ser melhor compreendida como um processo de inovação. De forma parcial, o mesmo se aplica à invenção. A tensão entre a criação e seu potencial “mercado" será o eixo mestre desta discussão, pois é este o fator que estabelece a fronteira entre eles. 
Assume-se, neste estudo, que para que a criatividade se transforme em inovação, é necessário um passo além: a atitude empreendedora. Assim, é possível estabelecer uma equação em que a criatividade, aliada ao empreendedorismo, resulta na inovação.

Neste capítulo, busca-se distinguir o conceito de criatividade de outros, tais como invenção, inovação e descoberta, como base para a discussão, no capítulo seguinte, da gênese dos empreendimentos inovadores. Para esta análise, far-se-á necessário retomar a idéia, exposta em capítulos anteriores, de que não há correlação necessária entre a criatividade e o sentido de utilidade. O fator utilitário relaciona-se, sim, com a inovação. Pretende-se, portanto, diferenciar esses dois conceitos, com base na tensão entre criação e mercado. 


\subsection{Criatividade, inteligência e sabedoria}

Embora não seja o objetivo do presente estudo, cabe distinguir inicialmente a criatividade da inteligência, conceitos que, por muitos anos, foram tratados como irmãos pela psicologia. Guilford, um pioneiro neste sentido e iniciador de um movimento para inclusão e valorização desta temática na psicologia, foi seguido, muitos anos depois, por Sternberg, que introduziu a sabedoria como síntese dialética entre a inteligência representante da tese - e a criatividade - a antítese (Sternberg, 2001).

Historicamente, a psicometria dedicou-se, especialmente durante o século XX, a mensurar a inteligência, tornando-a quase um sinônimo de QI, o coeficiente que a media. Gardner, autor da teoria das múltiplas inteligências, é um dos expoentes da crítica à visão simplificadora que a psicometria manteve e que se consolidou popularmente. Mais que isso, Sternberg (2003) ironiza o fato de que "inteligência é aquilo que os testes medem" e, se tal observação é jocosa, seus efeitos são sérios e importantes, pois, segundo o mesmo autor, uma indústria de testes de bilhões de dólares determina o que as crianças devem estudar nas melhores escolas e, posteriormente, nas universidades, embora a natureza essencial da inteligência possa estar distorcida a partir desta mesma indústria. Sternberg argumenta que a séria compreensão da inteligência precisa ir além dos testes-padrão baseados em papel e lápis, pois, para além das habilidades analíticas e quantitativas, residem as habilidades criativas, aquelas que permitem ir além da informação e possibilitam imaginar novas e excitantes formas de reformular velhos problemas. Autor de manuais amplos sobre o assunto, Sternberg (1999) dedica-se a inúmeros aspectos do tema criatividade, investigando, por exemplo, em 1995, o cultivo da criatividade em uma cultura da conformidade e, em 2005, propondo uma teoria da inteligência exitosa, definida 
como a habilidade de atingir os objetivos individuais na vida, dentro de determinado contexto sociocultural. Para o autor, as visões convencionais de inteligência favorecem os indivíduos com fortes habilidades memorísticas e analíticas. "O resultado é que indivíduos que [têm] os talentos para [atingir seus objetivos] na vida podem ser rotulados como nãointeligentes, ao mesmo tempo em que alguns dos que são rotulados como inteligentes podem ser menos dotados destes talentos" (Sternberg, 2005, p. 183, grifos do autor). Além disso, segundo Sternberg, pode-se possuir habilidades criativas, porém ser incapaz de utilizá-las, aspecto que será retomado para diferenciar criatividade e inovação.

Assim, para Sternberg (2005), inteligência é definida como "habilidade de adaptar-se ao ambiente e aprender com a experiência" (p. 183), mas o próprio autor levanta a ressalva: "Entretanto, na vida, adaptação não é suficiente" (p. 190). Espera-se que o indivíduo não só se adapte a um dado ambiente, mas seja capaz de tornar [esse ambiente] melhor, transformando-o ou escolhendo um novo ambiente que lhe possibilite expandir seu potencial, ou seja, uma habilidade criativa. Note-se que tal definição guarda muitas semelhanças com a questão da resiliência (Barlach, 2005).

Para Sternberg, podem existir pessoas inteligentes e criativas, porém tolas, o que pode suceder por cinco razões, a saber: a) otimismo não realista, acreditando ser tão espertas que tudo o que empreenderem "dará certo"; b) egocentrismo, agindo e pensando como se o mundo girasse a seu redor, desconsiderando interesses de outrem; c) onisciência, fantasiando-se especialistas em tudo, tornando-se suscetíveis às críticas por eventuais falhas; d) onipotência, pessoas com esta características, quando em posições de poder, podem perder a perspectiva dos limites e do alcance de seu poder pessoal; e) 
invulnerabilidade, considerado que escaparão ilesos (as) de qualquer situação e que são imunes à punição (p. 200).

Estas considerações remetem, sem dúvida, à distinção entre inteligência, criatividade e sabedoria, pois esta última incorpora os elementos éticos da relação do indivíduo consigo mesmo, com seus semelhantes e com o ambiente e transcende a mera adaptação conformista.

Outro aspecto importante na diferenciação entre criatividade e inteligência é apresentado por Guilford, ainda no ano de 1950: para ele, a criatividade não é um aspecto intelectual como a inteligência; trata-se de processo predominantemente perceptual e as decorrências deste fato são cruciais para sua mensuração, uma vez que os testes de inteligência medem fatores intelectuais.

\subsection{Entre a criatividade e a inovação: o mercado}

Um primeiro aspecto a ser discutido diz respeito às inúmeras formas criativas que não guardam relação com o utilitarismo. Koestler (1964) aponta para um tripé composto pelo humor, descoberta e arte e conclui que, se o humor faz parte deste tripé criativo e não tem função aparente a não ser a de "prover um relaxamento temporário das pressões utilitárias" (p. 31), não seria sustentável a hipótese do utilitarismo associado à criação. No caso do humor, é difícil atribuir-lhe valor de uso ou de troca, como na concepção clássica do valor. Embora possa haver sobreposições entre os dois conceitos, este caso ilustra que nem sempre o que é útil ganha sentido utilitário. A discussão remete aos conceitos de valor de uso e valor de troca, propostos por Marx (1867 / 1980). 
Pelas categorias de análise propostas por Marx, pode-se entender a criatividade humana como geradora de valor de uso e a inovação, de valor de troca. Desta forma, embora nem todo ato criativo gere uma inovação, toda inovação pressupõe um ato criativo ou, em outras palavras, o valor de uso sempre estará presente, mas o valor de troca dependerá da inserção social e econômica de uma criação ${ }^{27}$.

No entanto, autores como Georgsdottir \& Getz (2004) afirmam que a conceituação de criatividade e inovação dependerá da área de inserção de determinada pesquisa: se ela for procedida no campo da psicologia, o foco será na geração de idéias e se tratará como criatividade, enquanto, no campo da administração ou gestão, os aspectos de implementação de idéias serão relevados e a questão será tratada como inovação e, embora não muito esclarecedora, essa é, de fato, uma maneira de entender o problema que encontra espaço no senso comum.

Assim, o tema da distinção entre criatividade e inovação é polêmico. A maioria dos autores (e autoras) insiste na questão da utilidade associada ao novo para efeito de conceituar a criatividade. Desde a época de Ribot ([1906], 1973) entende-se que "em sua forma completa, a criatividade torna-se objetivada não só para a pessoa que cria, mas para todos que a cercam" (p. 11), dificultando, assim, a diferenciação entre os dois conceitos, mas incluindo-a na categoria platônica da objetivação, discutida no capítulo II.

Teresa Amabile - psicóloga social e professora de criatividade da Universidade de Harvard - argumenta que "a criatividade é a produção de idéias novas e apropriadas em qualquer

\footnotetext{
27 Baudrillard adiciona outros valores aos propostos por Marx, entendendo que a modernidade trouxe
} consigo a economia simbólica e este tema será abordado no capítulo V desta tese, ampliando esta visão. 
esfera de atividade humana, das artes à educação, dos negócios à vida cotidiana". Para ela, as idéias criativas são novas - diferentes do que havia antes - mas não podem ser simplesmente bizarras; elas devem ser apropriadas ao problema ou oportunidade presente (In: Pichard, 2002, p. 269). E continua: “Criatividade é o primeiro passo para a inovação, que é a implementação bem sucedida dessas idéias novas e apropriadas" (op. citada, p. 269). Também aqui se pode observar que, na ênfase ideacional associada à criatividade, a autora também está alinhada ao platonismo e à objetivação, mas essa abordagem tem o mérito de resguardar uma certa distância com relação ao utilitarismo ao afirmar a utilidade (e não o utilitarismo) como parâmetro para a idéia ser considerada criativa.

Já para West (2002), “a criatividade ocorre nos estágios iniciais dos processos de inovação e a implementação da inovação [é posterior]" (p.355). Para ele, a criatividade e a implementação da inovação "representam dois estágios do processo de inovação" (p. 356). Um aspecto importante identificado pelo autor é o fato de que as demandas externas dirigidas a grupos ou equipes que trabalham no desenvolvimento de inovações têm efeitos opostos em cada um desses estágios, a saber, "as demandas externas às equipes inibem a criatividade e a geração de idéias, mas encorajam a implantação das idéias criativas - ou a implementação da inovação" (p. 356). Este assunto será melhor desenvolvido no capítulo seguinte, quando será abordada a questão da criatividade e da inovação no contexto organizacional, mas cabe ressaltar aqui que a visão predominante na literatura entende a criatividade como o estágio inicial de um processo de inovação.

\subsubsection{Diferenças entre criatividade e inovação}


Sublinhando as diferenças entre criatividade e inovação, Haner (2005) aborda o desenho organizacional orientado para a criatividade e inovação, buscando entender os princípios dos processos subjacentes e suas implicações espaciais. Interessado em transformar a organização em centro de criatividade e inovação, propõe a implementação de "laboratórios de inovação" via encorajamento de comportamentos criativos e suporte a projetos inovadores. Para este autor, tanto a criatividade quanto a inovação têm fases com características ligadas ao pensamento convergente e divergente e dependem tanto de esforços individuais quanto grupais. Enquanto no processo criativo prevalece a convergência na fase de preparação e avaliação e a divergência nas fases de incubação e insight, na inovação o comportamento divergente prevalece na fase de geração da idéia (em que um emaranhado de idéias se apresenta de imediato ${ }^{28}$ ) ao passo que a convergência é prevalente na fase de validação do conceito.

Rank et al (2004) analisaram a relação entre criatividade e inovação no contexto da mudança organizacional, agregando à discussão diversos elementos importantes para a análise objeto desta tese. Para eles, a mudança organizacional envolve a transição de um estado corrente para um estado futuro desejado e há três processos psicológicos que facilitam tais transformações: a criatividade, a inovação e a iniciativa. Para eles, nem todas as mudanças envolvem inovação, mas, “certamente toda inovação em termos organizacionais é mudança" (West \& Farr, 1990, p. 11). Inovação diz respeito não somente ao desenvolvimento da organização inteira, mas também à transformação dos papéis individuais no trabalho e à implementação de novas idéias nos grupos ou equipes de trabalho (West \& Anderson, 1996). Concordando com Amabile (1996), esses autores afirmam que criatividade refere-se à produção de novas e úteis idéias por um indivíduo ou

\footnotetext{
${ }^{28} \mathrm{O}$ termo inglês fuzzy-front-end foi aqui traduzido livremente, de forma a manter o sentido original do texto.
} 
pequeno grupo de indivíduos trabalhando juntos enquanto inovação é definida como introdução ou aplicação intencional dentro de um papel, grupo ou organização de idéias, de processos ou procedimentos novos para unidade, relevantes para adoção, desenhados para beneficiar significativamente o indivíduo, grupo, organização ou a sociedade inteira (Rank et al, 2004). Resumindo, criatividade se refere à geração de idéias e inovação, à implementação destas. Elas diferem no grau de novidade da idéia e na interação social: a inovação refere-se a um processo social e interindividual, enquanto a criatividade a um processo cognitivo interindividual. À criatividade é atribuído o componente ideacional da inovação enquanto à inovação, a proposição e aplicação de novas idéias.

Referindo-se à gestão da criatividade e inovação nas organizações, Pichard (2002) afirma que as organizações hoje buscam recrutar pessoas criativas e, para mantê-las e estimulálas, "há textos que resumem como os [as] gerentes deveriam tentar desenvolver um clima de suporte à criatividade", além de como agir apropriadamente em relação ao seu "staff criativo". Entende-se que a supervisão excessivamente controladora reduz a motivação intrínseca - uma das questões-chave para a criatividade - e que a gestão deveria prover tarefas e trabalhos de complexidade desafiadora que ofereceriam altos níveis de satisfação pessoal aos empregados.

Para autores, como Vehar (2008), que preconizam a necessidade de maior rigor na utilização dos conceitos e na linguagem associada a este campo de conhecimentos, inovação "descreve o fenômeno da introdução de um novo produto que agrega valor", acrescentando que "a criatividade pode ocorrer no plano individual, enquanto a inovação requer a existência de equipes ou times que possam fazê-la acontecer". Nas palavras do autor, "A criatividade é uma condição necessária, mas não suficiente para a inovação" 
(Vehar, 2008), uma vez que, na inovação está implicada uma relação com uma determinada realidade social e a aceitação de uma inovação pela sociedade ou comunidade em que ela está inserida; trata-se de um processo que só termina com a introdução desta no mercado ou, segundo outros autores, pela criação de uma nova realidade social (Smulders, 2008, citado por Vehar, 2008).

Em resumo, conforme se viu até aqui, a criatividade está na base de qualquer processo de inovação; ela é condição necessária, mas não suficiente para que a inovação ocorra. A partir das questões propostas por Vehar, é possível constatar que entre a criatividade e a inovação há o problema de valoração do que é produzido - no processo de criação - e a viabilização operacional da idéia. Conforme se verá adiante, o processo de inovação envolve a criatividade e o empreendedorismo, atitude necessária para a viabilização das idéias.

O entendimento da criatividade e inovação como etapas que se completam prevalece na literatura, embora nem sempre a criatividade leve à inovação. Ressalte-se, porém, que, quando do estudo da criatividade, o fator inovação não estava presente, alicerçando a idéia de que criatividade é análoga a um verbo intransitivo, enquanto inovação, a um verbo transitivo.

\subsection{A tensão entre criação e mercado}

A existência de tensões entre o universo da criação e sua apropriação pelo "mercado" (ou público) é constante ao longo da história humana. Um dos fatores que explica esse processo diz respeito ao advento do sistema capitalista, que separou o produtor de seu 
produto (Marx, [1867], 1980). Criar para o mercado - ou para o público "consumidor" tem sido objeto de críticas por parte daqueles que defendem que a arte, por exemplo, deve se manter "pura" e desvinculada de sua futura inserção social, econômica ou profissional, ou que a mercantilização da arte ou indústria cultural (Benjamin, 1936 / 2000) pode comprometer a expressão do que é "realmente" criativo (Bilton, 2007). Neste contexto, caberia perguntar se a afirmação "criar para o mercado" não deveria ser substituída pela expressão "inovar para o mercado", uma vez que não há vinculação necessária entre a criação e sua aplicação ou implementação.

A passagem da criação à inovação envolve uma questão semelhante à que aborda Benjamin (1936 / 2000), ao analisar o processo histórico que levou à reprodução técnica da obra de arte. O autor afirma:

"o que murcha na era da reprodutibilidade da obra de arte é a sua aura. O processo é sintomático, o seu significado ultrapassa o domínio da arte. Poder-seia caracterizar a técnica de reprodução dizendo que liberta o objeto reproduzido do domínio da tradição. Ao multiplicar o reproduzido, coloca no lugar de ocorrência única a ocorrência em massa. Na medida em que permite à reprodução ir ao encontro de quem apreende, atualiza o reproduzido em cada uma das suas situações”. (p.4)

A aura "é a absoluta singularidade de um ser - natural ou artístico -, sua condição de exemplar único que se oferece num aqui e agora irrepetível, sua qualidade de eternidade e fugacidade simultâneas, seu pertencimento necessário ao contexto em que se encontra e sua participação numa tradição que lhe dá sentido" (Chauí, 1997, p. 320). Benjamin 
refere-se à aura no sentido em que esta derivava da inserção de uma obra no contexto da tradição, parte integrante dos cultos e rituais religiosos. A arte se separou dos rituais para ganhar o status de belas-artes a partir do final do século XVII, ocasião em que se distinguiu das artes mecânicas, cuja finalidade era o útil. A partir de então, o belo ficava reservado às belas artes e a utilidade, às artes mecânicas, acarretando uma separação entre técnica (o útil) e arte (o belo) e levando a imagem da arte a assumir o caráter de "ação individual espontânea, advinda da sensibilidade e da fantasia do artista como gênio criador". "Enquanto o técnico é visto como aplicador de regras e receitas vindas da tradição ou da ciência, o artista é visto como dotado de inspiração”. (Chauí, 1997, p. 318, grifos da autora).

A partir dessas considerações, é possível formular a pergunta: desapareceria, então, a aura na passagem da criação à inovação, uma vez que a aplicação de uma descoberta, por exemplo, implica outros objetivos que não a criação em si, podendo esta aplicação ser inclusive conflitante com aquilo que lhe deu origem?

A relação arte - mercado assumiu várias colorações ao longo da história. Tome-se, por exemplo, no universo da música, a história de Mozart, que compunha obras por encomenda de nobres e, em muitos momentos de sua vida, dependia destes pedidos para sua sobrevivência. Também Michelangelo pintou e entalhou o teto da capela Sixtina por encomenda do Papa Júlio II. A criação por encomenda, pelo patrocínio de mecenas, foi prática comum até o advento da indústria cultural. Na atualidade, a existência das curadorias para eventos culturais ou o patrocínio das pesquisas científicas por instituições ou organizações poderia ser entendida como uma nova configuração das velhas práticas dos mecenas e importa ressaltar que subsistem inúmeras atividades humanas que são 
promovidas quase que exclusivamente sob encomenda ou sustentadas por meio de patrocínio, como é o caso da arquitetura e da criação da moda feminina denominada alta costura.

De acordo com Carpeaux (1958), Beethoven é o primeiro a enfrentar um público desconhecido que não encomendou a obra, como era o costume até então, fazendo-o, em 1760, a convite da primeira empresa destinada a organizar concertos públicos não restritos a igrejas ou palácios. A burguesia é o novo público das composições musicais e os artistas, a partir de então, ficam sujeitos à avaliação mais ampla. Beethoven é também o primeiro a escrever somente por inspiração e vontade e não sob encomenda (p 128).

Para além desta questão - encomenda ou patrocínio das obras versus liberdade do artista -, uma outra emerge: embora grandes artistas como Mozart ou Michelangelo tenham vivido cercados por demandas utilitaristas, criando obras por encomenda, suas criações, inovadoras, não parecem ter perdido a aura mencionada na análise de Walter Benjamin. As ações destes e de outros grandes artistas superou ou transcendeu tais demandas.

A criatividade, então, pode ser considerada, até certo ponto, um processo autônomo que vai se beneficiar, ou não, da tensão criação - mercado. Um juízo de valor, por vezes externo à criação, apontará a utilidade (ou uso) da idéia. Mas, no contexto da distinção entre os dois conceitos, é relevante afirmar que a inovação estará sempre inserida num contexto histórico, encarregado de compará-la ao que existia anteriormente ou ainda poderá envolver a recriação frente a algo que foi superado. 
Assume-se, neste estudo, que a tensão "criação - mercado" é inerente ao processo criativo e que toda e qualquer criação, para se transformar em inovação, depende de uma avaliação - sobre seu valor - e de atitudes empreendedoras para se viabilizar, seja economicamente, seja socialmente, culturalmente ou ainda do ponto de vista comercial, sendo intrínseco à inovação o enfrentamento desta tensão.

A mesma questão sobre o desaparecimento ou não da aura permeia o debate moderno sobre a relação universidade - empresa ou, em outras palavras, a apropriação do conhecimento produzido pela universidade por setores produtivos da sociedade. No campo da inovação, o modelo da hélice tripla, proposto por Etkowitz (Etzkowitz\& Leydesdorff, 1996) e adotado por muitos estudiosos da área (Terra \& Plonski, 2006), pressupõe a possibilidade - ou necessidade - de atuação conjunta, entre a universidade, a empresa e o governo, mas esta relação tripartite só poderia ser considerada um modelo idealizado de harmonia, dificilmente encontrada na prática, em função dos diversos interesses presentes que geram a tensão mencionada. Este é um dos aspectos cruciais a ser pensado por aqueles (as) que desejam entender os processos psico-sociais associados à criatividade e à inovação.

Pressupõe-se, neste estudo, que, se a criatividade refere-se aos produtos únicos, singulares, sejam eles idéias, invenções, processos ou soluções de problemas, a inovação diz respeito à inserção dessas criações no mercado e, nesse sentido, seriam processos análogos à produção de singularities (criatividade) ou de commodities (inovações).

A seguir, aprofundam-se as diferenciações de termos correlatos à criatividade e à inovação, incluindo a descoberta e a invenção e discutem-se questões associadas a este 
campo de estudos, tais como a autoralidade da criação, o plágio e a propriedade intelectual.

\subsection{Invenção e descoberta}

Para autores como Couger et al. (1990), há uma relação entre criatividade e inovação que é semelhante àquela existente entre descoberta e invenção. Para eles, a invenção requer um propósito, sendo improvável existir uma invenção acidental; não se pode conceber uma invenção sem que o indivíduo que inventa esteja familiarizado com o estado da arte e com a variedade de técnicas de um dado campo de conhecimentos (p. 371). Por sua vez, a descoberta não requer um propósito claro. Diz respeito à percepção de alguma nova propriedade ou novo fenômeno ou nova verdade sobre algo; pode ser abstrata e, inclusive, inútil.

Ou seja, a invenção é predizível, ao passo que, em muitas descobertas, está envolvido um elemento acidental. A invenção envolve a tentativa deliberada de utilizar algum fenômeno particular para obter certo resultado; depende da consciência humana para unir os meios com os fins, ao passo que a descoberta é menos controlada, o fim é geralmente desconhecido e o evento básico pode levar o (a) cientista a um longo processo de investigação que, ao final, possibilita um resultado que parece muito diferente do buscado.

Outro aspecto importante no estudo do conceito de descoberta é a existência de multiplicidade nas descobertas, dificultando sobremaneira sua autoralidade. Descobertas envolvem cadeias de eventos e podem ocorrer simultaneamente para pessoas, grupos ou organizações separadas no tempo e no espaço. Fazendo referência à multiplicidade, 
Schaffer comenta a descoberta dos dinossauros e identifica que, em 1818, Buckland localizou o que, mais tarde, seria classificado como ossos de megalossauro em Stonesfield, de forma quase simultânea ao casal Mantell que, em 1822, desenterrou um conjunto de dentes fósseis na pedreira de Tilgate. Para Schaffer, citando Lamb e Easton, “[Esta] gradual mudança intelectual explica por que os restos de dinossauros foram encontrados em tão grande quantidade em um espaço de duas décadas, depois de terem repousado tranquilamente embaixo da terra durante vários milênios" (Schaffer, 1999, p. 45).

Entretanto, retomando a diferenciação de conceitos, há um outro tipo de relação entre os eles no que diz respeito à sua interdependência, a saber, o fato de que certas descobertas possibilitam invenções. Assim, por exemplo, a descoberta, na Física, dos efeitos eletromagnéticos permitiu a invenção de dispositivos tais como telégrafo, lâmpadas, motores e geradores que, em seu tempo, podem ser tomadas como inovações tecnológicas que alteraram significativamente a vida social e os processos produtivos.

Em síntese, descobertas podem ser fortuitas e, no sentido lato, são corriqueiras e cotidianas. Trata-se de algo que já existia, embora o indivíduo ou o estado da arte e do conhecimento de algum campo não estivesse ciente disso. O elemento pragmático ou utilitário é associado à invenção e à inovação. Da mesma forma que a invenção diz respeito à implementação da descoberta, a inovação diz respeito à implementação de idéias inventivas. Toda inovação é pragmática, uma vez que ela se refere à conversão de uma invenção em uma aplicação útil ou em um negócio. Invenções resultam em produtos, serviços e processos totalmente diferentes (Kurato \& Hodgetts) dos existentes até então. 
$\mathrm{Na}$ literatura, esses processos são exemplificados com as invenções do avião ${ }^{29}$, o bulbo da lâmpada, por Thomas Edison e o telefone, por Alexander Graham Bell.

Cabe perguntar, para efeito do presente estudo, se as descobertas são processos criativos e a resposta, considerando a criatividade como um verbo intransitivo, é positiva, pois a descoberta revela algo desconhecido para o indivíduo. Como discutido anteriormente a partir da teoria da Gestalt e também em seu sentido aristotélico, a identificação de novos significados tem sentido objetivante ou transcendente. A questão do reconhecimento da descoberta, entretanto, e seu eventual patenteamento, permanece como problemática tanto para o indivíduo quanto para a sociedade e para as organizações, de forma geral.

\subsection{Invenção e inovação}

Segundo Drucker (1985), o final do século XIX pode ser considerado como o século da invenção da invenção. Antes de 1880, invenção era atribuída ao "lampejo do gênio"; um inventor era tido como uma figura meio romântica, meio ridícula, remexendo coisas num sótão solitário. Por volta de 1914 - início da Primeira Guerra Mundial -, a "pesquisa" torna-se atividade sistematizada com propósito determinado, planejada e organizada, com alto grau de previsibilidade dos resultados almejados e das possibilidades destes serem alcançados. Para o autor, coisa semelhante precisa ser feita agora em relação à inovação, ou seja, segundo ele, os empreendedores precisam apoio para aprender a viabilizar a inovação sistemática.

\footnotetext{
${ }^{29}$ Os autores atribuem a invenção do avião aos Irmãos Wright. Esta afirmação é controversa, uma vez que, no Brasil, Santos Dumont é tido como o inventor do avião.
} 
Se é a mudança que proporciona a oportunidade para o novo e diferente, a inovação sistemática consiste na busca deliberada, na organização de mudanças e na análise sistemática das oportunidades que tais mudanças podem oferecer para uma nova realidade econômica ou social. Em geral, as mudanças já ocorreram ou estão em andamento, pois a maioria das inovações bem sucedidas explora a mudança (grifo do autor). Existem inovações que são mudanças, por si só, e existem inovações técnicas como o avião (acompanhando a tradição européia, o autor atribui a invenção aos irmãos Wright), derivadas de invenções.

Entre os conceitos de invenção e inovação não há uma relação unívoca. Assim, nem toda invenção se transforma em inovação e nem toda inovação é proveniente de uma invenção anterior. No contexto da inovação tecnológica e do empreendedorismo inovador, a distinção se dá no âmbito de um terceiro fator, a saber, o mercado. Enquanto a invenção pode prescindir de um mercado que possa utilizá-la ou adotá-la, só é possível definir a inovação em sua relação com um mercado. Além disso, a avaliação do potencial de aceitação de uma determinada inovação pelo mercado é prévia à sua implantação, o mesmo não ocorrendo quanto à invenção.

O exemplo da caneta descartável pode contribuir para a compreensão da distinção entre os dois conceitos. Antes da invenção da caneta Bic®, canetas tinteiro com grande durabilidade dominavam o mercado. "Em 1950, a [empresa] Bic teve a idéia de criar uma caneta descartável cuja duração de utilização seria limitada, mas cujo preço seria muito baixo" (Lubart, 2007). Com um protótipo desta nova caneta, buscou-se o contato com as empresas fabricantes na tentativa de viabilizar sua produção em escala industrial, mas a enorme rejeição da idéia demandou perseverança e espírito empreendedor até a introdução 
do novo produto junto ao mercado consumidor. As fábricas que produziam canetas alegavam que a "maioria das pessoas já possuía uma caneta de qualidade" e que "não haveria mercado potencial para tal produto", além do fato de que "as pessoas não [teriam interesse] em uma caneta descartável, já que elas poderiam ter uma caneta que durasse vários anos" (idem, p. 41).

A transformação de uma invenção em uma inovação envolve, portanto, a sua avaliação por parte de seus potenciais usuários e, na maior parte das vezes, o enfrentamento de resistências associadas a hábitos consolidados, estereótipos, preconceitos e vieses cognitivos de vários matizes (Barlach, 2008).

Assim, a distinção conceitual entre criatividade e inovação possibilita entender que a independência de opinião e o não conformismo, além da tendência a correr riscos, são características necessárias para indivíduos que atuam na fronteira entre a invenção e a inovação, ou seja, na apresentação de uma invenção para seus potenciais usuários por meio de uma inovação. De acordo com outros autores, estes elementos devem também estar presentes nos ambientes voltados à promoção da inovação para que o anticonvencionalismo possa ganhar expressão (Rank et al, 2004).

O reconhecimento, seja no caso de descobertas, seja de inovações, constitui o principal problema humano a ser compreendido, uma vez que dele depende a sensação de completude ou transcendência apresentada no capítulo II, intrinsecamente necessária para configurar plenamente a noção de criação. Assim, discutem-se, a seguir, a autoralidade e os direitos autorais como elementos componentes da análise. 


\subsection{Originalidade e autoralidade da criação: a problemática da avaliação e aceitação do novo pelo ambiente social}

Há um fator que permeia a criatividade, a descoberta e a invenção, mas não necessariamente a inovação, a saber, a autoralidade. Como se viu anteriormente, as descobertas são dúbias neste aspecto, podendo ou não ser reconhecida a autoralidade e, por vezes, haver o reconhecimento póstumo. A partir da idade moderna, o universo científico-tecnológico e artístico passou a reconhecer a autoria das obras, pesquisas e inventos. A assinatura do autor, tanto nas esculturas e pinturas quanto na arquitetura das catedrais, não era praxe durante a idade média. Nesta época, associava-se a autoria ao mandante da construção, que, em geral, era alguém da nobreza; somente a partir do século XVI, a autoria das obras passou a ser mencionada; exemplo disso é falar a "cúpula de Michelangelo", referindo-se à Capela Sixtina (De Masi, 2003).

A história do trabalho humano e das organizações tem na revolução industrial um marco de ruptura no que diz respeito à separação entre o autor e sua obra. Se, no período artesanal, mesmo que de forma anônima, havia uma relação entre o produtor e o produto, com o advento da indústria, a produção de bens é marcada pela alienação do produtor em relação ao produto de seu trabalho. A administração científica da produção, que tem em Taylor (1948) um de seus maiores ideólogos, interessou-se pela medição dos tempos e métodos do trabalho, reduzindo o ser humano à categoria de recurso produtivo. $\mathrm{O}$ elemento estético, presente no processo produtivo até a era industrial, dá lugar à produção massificada e este fato perdura até o movimento em prol da qualidade da produção, já em meados do século XX. Na história da administração, mesmo considerando que a gestão da qualidade total e a introdução dos círculos de qualidade foram propostas que visavam à 
recuperação do elemento estético no processo produtivo, elas não tiveram grande impacto em devolver ao ser humano a sua característica autoral.

Segundo Lubart (2007), "a divisão de trabalho, nascida com a revolução industrial, cria estruturas organizacionais caracterizadas pela hierarquia governada pelo controle de tarefas e, portanto, lentas para aceitar as mudanças. Nestas estruturas, o indivíduo que procura desenvolver um novo produto deve superar numerosos obstáculos, convencer colegas e superiores da qualidade de sua idéia em termos de utilidade, viabilidade e lucro, provar que o produto pode ser testado em pequena escala e que não haverá prejuízo para o funcionamento atual ou à imagem da empresa junto aos consumidores". Para o autor, "a expressão criativa no meio profissional fica reservada ao pequeno número de pessoas trabalhando para si próprias, nas organizações financiadas pelo Estado ou nos departamentos de P\&D de certas empresas" (p. 81). Vehar (2008) identifica, no discurso organizacional, algumas frases que caracterizam este processo, tais como: "Estamos muito ocupados para "ser criativos" ou "Precisamos fazer o trabalho de verdade por aqui" (Vehar, 2008, anotações verbais).

Além do aspecto da cisão entre produto e criador (a) e das dificuldades para "vender" uma idéia de forma a viabilizá-la, há ainda o elemento coletivo que se tornou preponderante especialmente a partir do século XX e que dificulta a identificação de autoria para a inovação, uma vez que, diferentemente da invenção e descoberta, que podem ser individuais ou coletivas, a [inovação] implica necessariamente um processo coletivo, com inúmeros (as) autores (as) envolvidos (as). Assim, as patentes, que atestam a propriedade autoral, são concedidas a inventores (as) ou descobridores (as) enquanto a inovação é 
avaliada e validada por outros meios, como premiações ou reconhecimento público ${ }^{30}$. No capitalismo da inovação, a passagem do aspecto imanente das criações para seu aspecto transcendente - o reconhecimento da autoralidade de uma obra - revela-se mais plenamente na propriedade intelectual.

\subsection{Propriedade intelectual e patentes}

Ciência básica ou inovação? Esta é a questão proposta por Rodrigues (2001), na discussão sobre a importância da ciência básica para o processo de inovação. Para ela, "a pesquisa básica, tradicionalmente a cargo das universidades, era vista como parte importante da rede que envolvia a inovação e o desenvolvimento de produtos". Esta prática se fundamentava na noção de que as inovações técnicas resultavam da aplicação de novas idéias ou descobertas científicas (p. 95). A linearidade deste modelo, que supõe que a ciência descobre, a técnica explora o novo conhecimento e fabricantes desenvolvem novos produtos, é atualmente questionada, mostrando que os laços entre ciência e desenvolvimento tecnológico vêm se enfraquecendo, ainda porque várias inovações não derivam de investigação científica e as descobertas têm recebido a contribuição de soluções práticas e de métodos previamente desenvolvidos de forma técnica. Em outras palavras, assiste-se a uma mudança nas relações entre a universidade, as empresas e a sociedade que impõe uma maior complexidade a estudos deste campo. O princípio da economia de mercado aplicado ao financiamento da pesquisa básica (Rodrigues, 2001, p. 95) relaciona-se diretamente com a tensão "criação - mercado", mencionada acima, e impacta a atribuição da propriedade intelectual, dentre outros aspectos do problema.

\footnotetext{
${ }^{30}$ Outros aspectos do processo de avaliação serão tratados ao longo do capítulo V desta tese.
} 
Patentes são algumas das formas de reconhecimento coletivo relacionadas a invenções e descobertas e, em vários momentos, aparecem como condição inicial do processo de inovação. Nelas [patentes], evidencia-se a questão de individualizar a descoberta ou invenção no contexto de criações, por vezes, coletivas, e da apropriação da patente pela organização, ou seja, entra em pauta a importância da autoralidade e as dificuldades desta no contexto organizacional.

A concessão de uma patente é um ritual de reconhecimento de autoria da criação original antes de sua reprodutibilidade. A discussão sobre propriedade intelectual e as patentes têm início com o exemplo da produção de conhecimento na área da informática, uma vez que esta área traz algumas características distintivas para o reconhecimento da criatividade e da inovação. Nesta indústria, é possível tipificar que "os programas de computador são normalmente patenteados, ao passo que os softwares são protegidos por direitos autorais ou copyright" (Couger et al., 1990). Assim, idéias e invenções são geralmente consideradas formas de "propriedade intelectual" ou produtos da mente e os métodos de proteger a propriedade intelectual, incluindo patentes, copyrights, marcas (trademarks) e segredos industriais (trade secrets). Nesta indústria, também o código fonte é passível de copyright. Ou seja, a "era do código" (Baudrillard, 1973 / 2000), embora ainda não tenha superado a era do signo, assume proporções cada vez mais hegemônicas, seja nessa indústria, seja na realidade virtual, nas comunicações, nos hologramas e na arte.

A propriedade intelectual - ou copyright, no caso de programas de computador, é regida pelo seguinte princípio: "Para um programa ser qualificado como passível de proteção pelo copyright, ele deve ser um trabalho original de autoria fixado em algum meio tangível de expressão que possa ser comunicado" (Couger et al., 1990, p. 373). A lei assume que, 
uma vez que existe um grande número de maneiras de expressar a mesma idéia, um (a) segundo (a) autor (a) não estará impedido (a) de criar um novo trabalho de valor.

As leis do copyright protegem as expressões, mas não as idéias, pois fica claro que é necessário que a idéia assuma algum meio tangível de expressão para que se aplique a lei; logo, a proteção não se estende à idéia subjacente, mas somente à maneira específica pela qual esta é comunicada (p.374), confirmando que, embora a criatividade - no plano ideacional - seja condição necessária para a inovação, ela não é condição suficiente, pois a concretude é critério para a propriedade intelectual ou, em outras palavras, para o reconhecimento da autoralidade.

No caso de patentes, a lei americana prevê que "Quem quer que invente ou descubra um novo e útil processo, máquina, manufatura, composição da matéria ou uma nova e útil melhoria (aprimoramento) daquilo pode obter uma patente daquilo" (act 35, USC 101). As leis de patentes, sejam elas norte-americanas ou brasileiras, reconhecendo que a tecnologia tende a crescer de maneira mais incremental, consideram que as melhorias são protegidas por um tempo significativamente mais curto que a duração do copyright. E também por isso, a lei de patentes não dá o direito aos que a possuem sobre o controle das invenções derivadas.

Tanto os direitos autorais quanto as patentes remetem à discussão do plágio e da cópia. A análise deste assunto aludirá também à engenharia reversa e sua relação com a cópia e o plágio.

\subsection{O problema do plágio e sua relação com a criatividade}


Muito famoso na imprensa especializada, o julgamento do caso Intel versus NEC (empresas da área de tecnologia) concluiu que a engenharia reversa utilizada pela NEC não violou o direito autoral (copyright) da Intel. A engenharia reversa foi o meio utilizado pela empresa NEC para tentar criar um código autoral que duplicasse a funcionalidade do código da Intel sem infringir a lei dos direitos autorais. O processo utilizado pela NEC envolveu duas equipes: uma trabalhou sobre o programa original, realizando inúmeros testes para determinar exatamente o que este fazia e como operava em cada tipo de situação. "Estes engenheiros não escreveram o software-clone. Eles passaram as especificações para uma segunda equipe que nunca havia visto ou tocado no hardware ou no software originais. Trabalhando apenas com as especificações funcionais, a segunda equipe escreveu uma implementação das idéias originais, funcionalmente compatível, sem ter tido oportunidade de copiar qualquer parte desta" (Couger et al., 1990, p. 374).

A distinção entre plágio e engenharia reversa, tratada neste caso, denota a engenharia reversa positivamente do ponto de vista da criatividade, mantendo a conotação negativa para o plágio, remetendo mais uma vez à dificuldade de definição precisa da originalidade contida na criatividade.

Também na música têm-se inúmeros exemplos que não podem ser consideradas como plágios, tais como as Bachiannas Brasileiras, de Villa Lobos, sobre as composições de Bach, ou as fantasias e variações produzidas por Louis Moreau Gottschalk sobre os hinos nacionais de vários países, pois estes autores não ocultam a origem, mas criam novas obras a partir das originais, sustentando a proposição de Latner (2003) que se refere à licença artística como um modelo do processo criativo e também as idéias de 
Nachmanovitch (1993) sobre a relação entre estrutura - espontaneidade, disciplina liberdade e formalismo (ou profissionalismo) - improvisação como elementos que devem ser equilibrados no processo criativo.

Os temas da engenharia reversa e das variações temáticas na música remetem à questão sobre como são concedidas as patentes e também quais os critérios para a atribuição de direitos autorais. No caso da indústria da informação, a maneira como é expresso um programa interessa tanto quanto a idéia em si e um dos requisitos para o copyright de softwares é a demonstração de que o trabalho é original, implicando em não obviedade, resultando, mais uma vez, em confusões sobre os conceitos de criatividade e inovação (Couger et al., 1990). Conforme mencionado anteriormente, para efeito desta tese, foi estabelecida uma analogia entre a criatividade e o verbo intransitivo. Ao analisar os parâmetros para concessão de patentes ou direitos autorais, fica claro que a criatividade é elemento necessário, mas não suficiente, pois não basta que se possa alcançar o reconhecimento de uma criação. Tampouco a conceituação da criatividade como atribuição de novos significados, como na teoria da Gestalt, poderia colaborar para o bom entendimento da autoralidade nesta esfera. O sentido transcendente, de instituição da alteridade, é prevalente neste campo.

\subsection{Criatividade, inovação e empreendedorismo}

Inovação é o processo pelo qual as descobertas e invenções são reconhecidas como oportunidades e convertidas em algo vendável ou comercializável (marketable). Peter Drucker (1985), em seu livro Innovation and Entrepreneurship, afirma que "a inovação é a função específica do [a] empreendedor [a]... é o meio pelo qual ele [ela] cria novos 
recursos produtivos de riqueza ou dota os recursos existentes de potencial aumentado para criar riqueza" (In: Couger et al., p.374).

Outra definição de empreendedor (a) diz respeito "àquele (a) que se incumbe da concepção e do desenvolvimento de um novo negócio, fazendo tudo aquilo que é necessário para que o empreendimento avance e assumindo responsabilidade última por todos os aspectos de seu desenvolvimento, do financiamento à distribuição e que assume maior risco e pode esperar uma maior parcela de lucros" (Brownstone, 1980, p. 101 In: Couger et al., 1990, p. 374).

Para Kuratko (2003), empreendedorismo “é o novo e diz respeito à inovação contínua e à criatividade" (p. 22, grifo do autor). Em uma discussão sobre as tendências e desafios da educação empreendedora no século XXI, o autor afirma que as palavras de ordem deste contexto são: “Sonhe!, Crie!, Explore!, Invente!, Seja pioneiro! e Imagine!” (p. 22). Em sua análise, conceitua empreendedorismo, de forma ampliada, como "um processo dinâmico de visão, mudança e criação [que] requer a aplicação de energia e paixão e implementação de novas idéias e soluções criativas" (p.2). Para este autor, empreendedorismo "é mais que a mera criação de negócios", pois a perspectiva empreendedora pode se apresentar dentro e fora de organizações, em empresas que visam lucro ou não, em atividades de negócios ou não, pois o que é essencial na referida perspectiva é o propósito de trazer à tona idéias criativas (p. 2). Assim, "empreendedorismo é um conceito integrado que permeia um negócio individual de maneira inovativa" (p. 2). Em função desse conceito e baseado nas propostas de educação empreendedora das melhores instituições mundiais, este autor entende que o desenvolvimento de competências empreendedoras deve abranger o chamado "ciclo de 
negócios", a saber, criatividade, reconhecimento de oportunidade, invenção ou descoberta de um produto ou serviço, avaliação da oportunidade de negócio, construção do mercado e do sistema de entrega, crescimento e renovação.

Também Drucker (1987) entende que "a inovação é o instrumento específico do espírito inovador" (p. 39), pois a inovação cria um recurso e não existe algo que possa ser denominada recurso até que o ser humano encontre um uso para alguma coisa na natureza e assim, o dote de valor econômico. Entretanto, este autor associa o empreendedorismo a um espírito que pode estar presente mesmo que ele não se materialize numa "coisa", impondo-se novamente a problemática conceitual anteriormente discutida. Menciona exemplos de inovações sociais, como a criação do hospital, cuja concepção teve impacto significativo na assistência médica ou as "compras a prazo" que, literalmente, transformaram a economia. Em sua análise, inclui a inovação representada pelo "container" utilizado na marinha mercante, que envolveu a idéia de "tirar uma carroceria de caminhão e colocá-la num navio cargueiro". "Esta inovação trivial quase quadruplicou a produtividade do cargueiro marítimo e provavelmente salvou a marinha mercante" (p. 40), embora só tenha exigido uma percepção do navio como sendo um equipamento de manipulação de cargas, ao invés de vê-lo como meio de transporte de passageiros e estabelecer a analogia com a carga de um caminhão, num exemplo claro do que se conceituou como objetivação no capítulo II. Portanto, inovação, para Drucker, é uma designação econômica e social, mais do que um termo técnico.

As pessoas bem sucedidas no empreendedorismo, "tentam criar valor e fazer uma contribuição", mas não se contentam em "melhorar o que já existe ou em modificá-lo. [...] Procuram criar valores novos e diferentes e satisfações novas e diferentes, convertendo um 
material em um recurso ou combinar recursos existentes em uma configuração nova e mais produtiva" (p. 45). Uma vez que a mudança é aquilo que proporciona a oportunidade para o novo e o diferente, a inovação consiste na "busca deliberada e organizada de mudanças e na análise sistemática das oportunidades que tais mudanças podem oferecer do ponto de vista econômico ou social”. (Drucker, 1987, p. 45).

Há, para Drucker, uma disciplina da inovação, que envolve um exame sistemático das áreas de mudança que tipicamente oferecem oportunidades empreendedoras, por meio do monitoramento de sete fontes, a saber: a) o inesperado: o sucesso, o fracasso ou o evento inesperado; b) a incongruência: entre a realidade (como ela é, de fato) e a realidade como se presume ser ou como deveria ser; c) a necessidade de processo; d) as mudanças na estrutura de determinado setor ou na estrutura de mercado; e) as mudanças demográficas (populacionais); f) as mudanças em percepção, disposição ou significado; e g) o conhecimento novo, tanto científico como não-científico.

Alerta o autor, de forma semelhante à Platão, para a existência de uma cegueira, no cotidiano, para tais fatores, em função da tendência humana a focalizar as áreas-problema e não nas soluções. Inúmeros erros e características semelhantes ao efeito Einstellung, que será descrito no capítulo V, são apresentados por Drucker.

\subsection{Empreendedorismo inovador: paixão e emancipação humana}

Quatro são as possibilidades de pesquisa sobre empreendedorismo identificadas por Rindova et al. (2009): a) a criação de novas organizações; b) a criação de negócios de alto valor agregado; c) a inovação e criação de novos produtos e mercados [os autores 
mencionam, neste caso, a concepção de Shumpeter] e d) o reconhecimento e persecução de oportunidades lucrativas. Os autores propõem, para além destes, a investigação sobre o empreendedorismo "como processo emancipatório com potencial de mudança mais amplo", a consideração de "indivíduos [que] geralmente se engajam em ações empreendedoras por motivações outras que não o dinheiro" (p. 477), ressaltando a importância do fator humano no processo de empreender. Como na história de Jim Corman, que era vice-presidente sênior de um provedor de serviços de telefonia de longa distância e, apesar de seu alto prestígio e remuneração, sentia-se "miserável”. Dizia ele: As decisões eram lentas, eu tinha pouco controle do ambiente de trabalho e todas as decisões corporativas eram dominadas pelo impacto que teriam sobre os rendimentos do próximo quadrimestre. Quando seu chefe lhe pediu para demitir pessoas num esforço para aumentar esses rendimentos, ele se recusou e deixou a companhia. Criou a Touch $1 \mathrm{com}$ a esperança de dar empregos a sessenta de seus vizinhos (Rindova et al., 2009, p. 477).

Cardon et al. (2009) apóiam-se em Schumpeter, buscando entender como a paixão poderia explicar comportamentos empreendedores que desafiam a visão racional, tais como correr riscos de forma não convencional, foco de intensidade incomum e crença em seu sonho. Estudando o que é paixão e que efeito ela tem nos negócios, discutem qual é o objeto da paixão do (a) empreendedor (a), se o negócio em si, a detecção de oportunidades, a criação de um produto, as tarefas ligadas ao negócio. E concluem que, para um (a) empreendedor (a), é o seu trabalho que constitui o objeto da paixão. A paixão está relacionada à motivação, à tenacidade, ao desejo de trabalhar por muitas horas, à coragem e aos altos níveis de iniciativa e persistência frente a obstáculos. De acordo com os autores, a paixão aumenta a criatividade e o reconhecimento de novos padrões, o que 


\section{é fator crítico para a exploração e aproveitamento de oportunidades em ambientes incertos e de risco.}

De maneira semelhante às proposições de Maslow (1971), De Charms (1968) e McClelland et al. (1953), discutidas no capítulo III, os autores entendem que a paixão empreendedora é definida como um sentimento positivo intenso, acessível conscientemente, resultante do engajamento em atividades com sentido de identidade e saliência para o empreendedor. Ela [paixão] promove estados intensos de fluir e total absorção em suas atividades, fazendo com que as pessoas invistam tempo e energia, manifestem entusiasmo, zelo e intensa duração da sua atenção. Atividades são intensamente significativas, os objetos são reais, desejáveis e passíveis de memória, podendo ser imaginados e antecipados (Cardon et al., 2009, p. 512).

Os aspectos emancipatórios do empreendedorismo estão ligados aos sonhos e esforços para criar mudanças no mundo. A relação entre empreendedorismo e criatividade fica evidenciada na definição de Cardon et al. (2009): "esforços para constituir novos ambientes econômicos, sociais e culturais por meio das ações de indivíduos ou grupos [...] criação de algo novo - uma nova idéia, uma coisa nova, uma nova instituição, um novo mercado, um novo conjunto de possibilidades para o indivíduo ou grupo empreendedor e/ou para outros atores no ambiente" (p. 477 e 478).

Emancipação é o ato de tornar-se livre do poder do outro (p. 478), a persecução de liberdade e autonomia. A proposta de Rindova et al. (2009) é entender os fatores que levam os indivíduos a buscar romper com o status quo e mudar a sua posição na ordem social em que estão inseridos e, por vezes, mudar a própria ordem social. Para esses 
autores, a motivação para empreendedorismo é o desejo de liberdade e independência para com as estruturas convencionais de autoridade e de geração de riquezas, desejos por autonomia, por expressar sua própria criatividade, perseguir a inovação e ser seu próprio patrão.

Confirmando a visão de McClelland et al. (1953), Rindova et al. afirmam que o ímpeto empreendedor revela o desejo de ficar livre da autoridade e quebrar com as restrições percebidas. Não se trata somente de perseguir oportunidades, mas de superar ou remover obstáculos, restrições percebidas no ambiente dos atores. Uma vez que tais restrições podem ser de natureza intelectual, psicológica, econômica, social, institucional ou cultural, resolve-se a distinção entre empreendimentos lucrativos e não-lucrativos, pois, ao enfatizar a criação de mudanças, a perspectiva emancipatória não nega a criação de riqueza. A autonomia é um dos fatores motivadores mais poderosos para se tornar autoempregado, é o desejo de fazer seu próprio caminho no mundo. Na visão de Schumpeter, o empreendedorismo é tido como "destruição criativa". Rindova et al. afirmam que a perspectiva emancipatória vai além, pois considera tanto a construção quanto a destruição; a destruição criativa pode ser um dos objetivos do empreendedorismo.

Esses autores entendem o empreendedorismo como criação e ampliação de caminhos onde anteriormente existiam relações sociais e econômicas estáveis (e potencialmente rígidas) que impunham restrições a certos tipos de atividades que os (as) empreendedores (as) - ou outros membros de seu círculo social - valorizam (p. 480).

"É possível entender qualquer trabalho como produto da escolha entre a facilidade e o sucesso convencional e os problemas e a falta de reconhecimento relativa ao 
inconvencional" (p. 482). As convenções tornam as atividades coletivas mais fáceis e menos custosas em tempo, energia e outros recursos; elas não tornam o trabalho inconvencional impossível; somente mais custoso. A diferença relativa aos recursos que são requeridos é a medida da força da restrição imposta pelo sistema convencional; restrições são não apenas superadas, mas também removidas.

Vale ressaltar que ambos os estudos (Cardon et al., 2009 e Rindova et al., 2009) consideram os distintos aspectos do comportamento empreendedor, que podem se expressar em diferentes momentos do processo ou como distintas identidades. O momento de detecção de novas oportunidades é distinto do momento da criação de uma nova organização. As identidades empreendedoras - ser um inventor, um fundador ou um desenvolvedor - também ganham expressão nos dois trabalhos.

Para Cardon et al. (2009), a existência dessas diferentes identidades pode explicar diversas questões, dentre elas, o porquê os (as) empreendedores (as) que evidenciam alta paixão quando o negócio estava nascendo perdem-na à medida que o negócio cresce? Ou ainda, por que alguns apaixonados por sua idéia abrem mão dela para que outros desenvolvam o negócio e extraiam valor deste crescimento? Finalmente, porque alguns continuam e persistem enfrentando todo tipo de obstáculo e impedimento (p. 511)?

Entendem os autores que é possível identificar a existência de três identidades ligadas ao empreendedorismo, a saber: a) identidade de inventor (ou inventora), em que a paixão empreendedora é por atividades envolvidas em identificar, inventar e explorar novas oportunidades; b) identidade de fundador (a), em que a paixão empreendedora é por atividades envolvidas em estabelecer um negócio para comercializar e explorar 
oportunidades e c) a identidade de desenvolvedor (a) / realizador (a), cuja paixão é por atividades relativas a nutrir, fazer crescer e expandir o negócio já criado (Cardon et al., 2009, p. 516).

Empreendedores (as) encontram significado interno em cada uma das identidades. Aquela que for saliente e distintiva motiva o (a) empreendedor (a) a se engajar em certas atividades (e desengajar de outras). A identidade resulta em uma fonte de motivação para ações que validam socialmente o auto-conceito.

A identidade de inventor (a) envolve a busca de novas idéias, o brincar com o desenvolvimento de novos produtos e também o monitoramento do ambiente para oportunidades disruptivas de mercado. Por sua vez, a identidade de fundador (a) inclui a paixão por atividades que envolvam juntar os recursos necessários para criar uma firma, incluindo os financeiros, e a identidade de desenvolvedor (a) afirma a paixão por engajarse em atividades relacionadas ao desenvolvimento de mercados (atrair novos clientes) e crescimento financeiro (criação de valor). Uma vez que não há necessariamente uma única identidade dominante, pode ocorrer que a paixão pelo papel de inventor seja tão grande que a pessoa nunca realmente tente levar seu produto para o mercado ou explore realmente a oportunidade. Pode ocorrer também, se a identidade de fundador for saliente, que o indivíduo venda a firma para outros (as) que estejam mais interessados (as) em fazê-la crescer para realizar todo o seu potencial de mercado.

Empreendedores (as) diferem no grau em que podem regular suas emoções e suas respostas comportamentais para lidar efetivamente com a realidade, especialmente quando múltiplos estados emocionais associados com identidades não integradas consistentemente 
são ativados. Pode ocorrer a sub-regulação, ou seja, a inabilidade para controlar ou equilibrar estados emocionais internos, dando lugar a respostas impulsivas ou a superregulação, envolvendo a supressão de um ou mais desses estados internos, acarretando a falta de resposta espontânea.

Quando uma identidade é ativada, espera-se que a experiência da paixão mobilize os processos de auto-regulação do (a) empreendedor (a) que estão dirigidos à efetividade no alcance da meta empreendedora correspondente. Esses objetivos, por sua vez, envolvem a validação da identidade focal pelo engajamento cognitivo e comportamental em atividades da maneira característica das intensas emoções positivas.

Empreendedores (as) tomados (as) pela paixão evidenciam engajamento comportamental em atividades empreendedoras caracterizadas por: a) solução criativa de problemas, definida como a produção de idéias ou ações novas e úteis; b) persistência, definida como a continuação do esforço de ação apesar dos fracassos, impedimentos, ameaças, tanto reais como imaginários e c) absorção, definida como estar completamente concentrado (a) e profundamente mergulhado (a) em seu próprio trabalho. Observam os autores que persistência refere-se à duração do engajamento na tarefa e a absorção, ao nível desse envolvimento.

Estaria a possibilidade de viver a paixão e alcançar a emancipação comprometida nos ambientes organizacionais? Tendo explorado a criatividade e o trabalho criativo e diferenciado, de forma preliminar, a criatividade da inovação, importa agora delinear os principais aspectos envolvidos no processo criativo no interior das organizações e discutir a gênese dos empreendimentos inovadores, pressupondo que os determinantes 
organizacionais configurem esses processos de forma distinta de outros contextos, o que será feito no capítulo seguinte.

\subsection{Criatividade e conceitos correlatos}

Embora invenções, descobertas, criatividade e inovação sejam conceitos passíveis de diferenciação quando analisados a partir do rigor científico, eles se confundem como categorias de prática, sendo frequentemente tratados, no discurso cotidiano, como sinônimos.

De fato, são atividades que se sobrepõem no processo inovador-empreendedor, no qual se observa claramente uma elaboração criativa da condição humana, seja aquela objetivação, transcendência, ou combinação de elementos, à qual se somam participações diversas, advindas das descobertas, invenções e outras. Para além do ato criativo, a atividade de inovação empreendedora implica o manejo do contexto / ambiente no sentido de construção de uma dada arquitetura. Inteligência, criatividade e sabedoria participam do percurso de gestação da inovação: a inteligência possibilita a identificação dos desafios e respectiva produção de respostas; a criatividade, a transformação destes em oportunidades e fonte do elemento sublime da resposta, que não se limita à eficácia; e a sabedoria que permite, a cada momento, definir o que manter e o que mudar / transformar nos ajustes que a adaptação humana requer. 
Capítulo V 


\section{A criatividade no universo das organizações e dos negócios}

É a partir do design como categoria central do processo de produção na economia contemporânea que a criatividade se torna cada vez mais presente nas organizações e nos negócios atuais. O design transcende o mero valor de uso, incorporando valores simbólicos, imagéticos, funcionais e ergonômicos, configurando uma resposta adequada à fase do capitalismo que se apóia na idéia de diferencial como fundamento da escolha. Entretanto, no contexto do trabalho organizado, a criatividade do design tem que enfrentar as barreiras dos modelos de gestão que se cristalizaram ao longo de toda a era industrial. Originários da teoria da administração científica (Taylor, 1948), as teorias e práticas da gestão se desenvolveram a partir de pressupostos tais como evitar o erro, maximizar a eficiência e eliminar a subjetividade o que, de forma geral, é impeditivo ou dificultador da criatividade. Em outras palavras, o sentido estético e a subjetividade humana, por muitos anos exilados nas artes, ressurgem no processo produtivo, mas devem enfrentar todo tipo de barreiras num cenário que lhes foi hostil até então. Assim, os discursos e as máximas da inovação hoje professadas ainda não encontram ressonância no clima e na cultura organizacional. Essa é uma das características que explicam o chamado efeito Einstellung e a "armadilha do sucesso" e acentuam a necessidade de ambidestria organizacional.

Investigar como a criatividade se insere na dinâmica das organizações é o objetivo deste capítulo. O impacto das estruturas e da cultura organizacional será um dos assuntos aqui discutidos. Nesse capítulo, retoma-se também a relação entre o empreendedorismo e a criatividade, revelando a força emancipatória e identitária oriunda da criação de novos empreendimentos por parte de pessoas que tiveram projetos criativos e inovadores 
rejeitados por organizações nas quais trabalhavam. São esses os parâmetros para a análise dos dados empíricos coletados para efeito desta tese, objeto do capítulo seguinte. 


\subsection{A nova fase do capitalismo}

Thrift (2006) identifica duas direções opostas na evolução atual da economia. Por um lado, a exploração e a acumulação primitiva que ainda prevalecem em muitas partes do mundo, em especial naquelas em que predomina a economia do óleo, gás, gemas e nos países que dependem de atividades ilegais, como contrabando, drogas, lavagem de dinheiro e tráficos de toda ordem. Por outro, há a tendência denominada por ele "economia das qualidades"31, que pode ser descrita a partir de duas características: a) a centralidade do design, que passa a permear todo o processo produtivo, transformando-se em categoria central da inovação; e b) a alteração da equação produção - distribuição - consumo em função da participação cada vez maior dos (as) consumidores (as) na co-criação dos produtos e serviços. Aludindo às inovações abertas, afirma o autor que, nesta economia, aqueles (as) que produzem e aqueles (as) que consomem não se encontram somente ao final do processo, mas em inúmeras situações ao longo dele (Thrift, 2006, p. 279 e 280).

Mais ainda, esta situação atual do capitalismo pode ser denominada economia da experiência, uma vez que "nem produtos, nem serviços constituem a base do valor", pois este [valor] está incorporado nas vivências criadas pelo indivíduo num ambiente experimental que a empresa co-cria com os consumidores (Trhift, 2006, p. 290). A mercadoria não é mais uma coisa fixa, mas um experimento aberto de inovação cujo propósito maior agrega o estímulo às emoções (p. 288).

\footnotetext{
${ }^{31}$ Economia das qualidades, para o autor, designa um "ambiente preenchido com inteligência aplicada [...] envolto em constante interação e feedback" (p. 291).
} 
Duas decorrências derivam do estudo de Thrift (2006): a primeira, a presença da categoria estética, mencionada quando da conceituação da criatividade ${ }^{32}$ e a segunda, apontada pelo próprio autor, o espaço organizacional que se abre para invenções e experimentos e também para novas formas de consumo em que "o mero uso é superado pelo prazer da atividade em si, na qual a mercadoria é uma parceira ativa" (p. 290). Assim, o mercado não está mais somente voltado para a venda de mercadorias, mas para a oferta de experiências. O sentido de eficácia se transforma, demandando que o capitalismo se torne tanto um negócio quanto uma arte liberal, pesquisando constantemente as paixões e entusiasmos dos (as) consumidores (as), capturando e trabalhando o potencial das coisas serem diferentes daquilo que são (Tarde, 2007). O que vale no capitalismo atual é, portanto, capturar as expectativas e desenvolver o potencial de forma a atender ao (à) cliente. Confirma-se, assim, a importância da criatividade no universo atual dos negócios e na chamada "economia das qualidades" (Trhift, 2006), tornando-se importante estudar seus componentes e a especificidade do que se produz, bem como as formas aí assumidas e legitimadas. Isso poderá ser melhor compreendidas ao acompanhar as considerações de Jean Baudrillard ([1973], 2000; [1981], 2005) sobre os padrões de consumo e as características dos objetos, símbolos e signos da era atual.

\subsubsection{A questão semiótica do novo no contexto industrial e pós-industrial}

Baudrillard ([1973], 2000), em uma análise comparativa do objeto pré-industrial com relação ao modelo industrial, afirma que o estatuto do objeto moderno é dominado pela oposição modelo / série. Antes da era industrial, não seria possível falar nem em modelo nem série, uma vez que, naquela sociedade, a homogeneidade entre os objetos era maior, porque em seu modo de produção prevalecia o trabalho à mão, havia menos especialização

\footnotetext{
${ }^{32}$ Ver capítulo II desta tese.
} 
em sua função e o leque de formas culturais era menos vasto. $\mathrm{O}$ exemplo utilizado pelo autor é o da "mesa Luiz XV”, que, no século XVIII, guardava pouca relação com a mesa campesina: "um fosso separa as duas categorias de objetos como as duas classes sociais a que pertencem" (p. 146). E acrescenta que "não se pode, tampouco, dizer que a mesa Luís XIII [tenha sido] o modelo da qual as inúmeras mesas e assentos que em seguida a imitaram vêm a ser a série" (p. 146). O modelo permanece ligado à transcendência e série alguma provém dele, no sentido moderno do termo. E conclui que o equivalente para os objetos desta concepção transcendente é hoje, o estilo. Há, portanto, uma distinção entre objetos "de estilo", pré-industriais e os modelos atuais que deve ser levada em conta na análise das relações entre modelos e séries no sistema contemporâneo de produção. Ao adquirir um objeto de série, adquire-se, concomitantemente, o estilo.

No universo moderno, estabeleceu-se "em nome da informação e da comunicação de massa que difundem tais modelos, uma circulação não somente dos objetos, mas uma circulação "psicológica" que assinala a diferença radical entre a era industrial e a préindustrial de transcendente distinção de "estilo"” (p. 147). A aquisição e o uso de um objeto de série, para largas camadas da população, são imbuídos de modelos. Observa o autor que existem, cada vez menos, modelos ou séries puras, "a transição de um a outro vai se diferenciando ao infinito".

Referindo-se ainda à modernidade, Baudrillard ([1973], 2000) aborda o objeto personalizado (p. 146) que aparece, de maneira mais evidente, na indústria vestuário, que contrapõe vestidos assinados por costureiros (as) famosos (as) ao "prêt à porter". Dessa forma, introduz a diferença entre modelo de luxo e modelo de série, ponto de menor resistência da noção de modelo. Mas o mesmo não vale para os objetos coletivos, as 
máquinas, pois uma máquina pode ser mais "moderna" que outra e nem por isso se torna um "modelo" das quais outras, menos aperfeiçoadas, constituiriam a série.

Nas máquinas, como por exemplo, os tratores e as prensas industriais, a noção de modelo de luxo / modelo de série, além de ser menos evidente, não se constitui a base para dinâmicas psicológicas que se estabelecem a partir dos objetos. "A dinâmica psicossociológica do modelo e da série não atua, pois, ao nível da função primária do objeto, mas ao nível de uma função segunda, que é a do "objeto personalizado"” (p. 149). Daí decorre que a sociedade industrial, se comparada à pré-industrial, é a sociedade da escolha, pois "objeto algum é oferecido ao consumo em um único tipo. [...] O que pode ser recusado [a você] é a possibilidade de comprá-lo. Mas aquilo que [lhe] é dado a priori na nossa sociedade industrial como graça coletiva e como signo de uma liberdade formal, é a escolha. [...] Sobre tal disponibilidade repousa a "personalização". E é na medida em que todo um leque lhe é oferecido que o (a) consumidor (a) ultrapassa a estrita necessidade da compra [...], [pois] não há mais a possibilidade de não escolher e simplesmente comprar um objeto em função do uso" (p. 149, 150, grifos nossos).

Na sociedade da escolha, "nenhum objeto se propõe como objeto de série e sim todos como modelos" e cada objeto se distingue dos outros em função de alguma diferença, seja ela cor, acessório ou detalhe. Tais diferenças são, no entanto, marginais ou, segundo o autor, inessenciais, pois a exigência de personalização só pode ser satisfeita no plano da inessencialidade. "Para personalizar os automóveis, o produtor unicamente pode tomar um chassi de série, um motor de série, modificar algumas características exteriores ou acrescentar alguns acessórios ${ }^{33}$. O automóvel, na qualidade de objeto técnico essencial não

\footnotetext{
${ }^{33}$ Como se verá adiante, esta seria a base das inovações incrementais, bastante difundidas nas organizações atuais.
} 
pode ser personalizado, só os aspectos inessenciais é que o podem" (Baudrillard, [1973], 2000, p. 150). Muitas vezes, como diz Baudrillard, "a função de personalização não é somente um valor acrescentado, é um valor parasitário”. E continua afirmando que essas diversas combinações de aspectos inessenciais são por sua vez retomadas e serializadas na produção industrial. "É esta seriação segunda que constitui a moda" (p. 151) que produz séries sempre mais limitadas fundadas sobre diferenças cada vez mais ínfimas e específicas. Assim, "não há mais modelos absolutos que se oponham categoricamente a objetos de série destituídos de valor". Baudrillard deduz da análise precedente que o consumo, como uma modalidade característica da sociedade industrial, não é um processo de satisfação de necessidades, mas um modo ativo de relação não apenas com os objetos, mas com a coletividade e com o mundo, um modo de atividade sistemática e de resposta global no qual se funda todo o sistema cultural (p. 206).

A separação "modelo - série" não se aplica a objetos de design, categoria anteriormente mencionada, pois a própria expressão diz respeito àquilo que é único, exclusivo, singular, sendo sua pluralização ou comodificação uma descaracterização total do mesmo.

Em outra obra, o mesmo autor introduz a noção de simulacro, a partir da história dos indígenas da Melanésia que, sentindo-se maravilhados com os aviões que viam passar nos céus, lançaram-se a construir um simulacro, "delimitaram um espaço que iluminavam à noite e punham-se pacientemente à espera que os verdadeiros aviões ali viessem aterrisar". (Baudrillard, [1981], 2005, p. 21). Para ele, é o pensamento mágico que governa o consumo, uma mentalidade sensível ao miraculoso que rege a vida cotidiana, representada pela crença na onipotência dos signos (p. 22, grifos do autor). O autor compara a atitude dos indígenas aos telespectadores que "apertam o botão e esperam que as imagens do 
mundo todo venham até [ele]" e a diferença entre o mundo real e o imaginário, de natureza técnica, não invalida a comparação, pois também pode estar presente o pensamento mágico na consciência do (a) consumidor (a) (p. 22).

“A era do consumo, em virtude de constituir o remate histórico de todo o processo de produtividade acelerada sob o signo do capital, surge igualmente como a era da alienação radical". Generalizou-se a lógica da mercadoria, que regula hoje não só os processos de trabalho e os produtos materiais, mas a cultura inteira, a sexualidade, as relações humanas e os próprios fantasmas e pulsões individuais. "Tudo foi reassumido por esta lógica, não apenas no sentido de que todas as funções, todas as necessidades se encontram objetivadas e manipuladas em termos de lucro, mas ainda no sentido mais profundo de que tudo é espetacularizado, quer dizer, evocado, provocado, orquestrado em imagens, em signos, em modelos consumíveis” (Baudrillard, [1981], 2005, p. 205, grifo do autor).

A análise de Baudrillard (2000, 2005) possibilita a discussão da economia dos signos ou o "valor de signo" dos objetos, que transcenderia tanto seu valor de uso quanto o de troca. Assim, se o valor simbólico de um objeto é irredutível tanto ao valor de uso quanto ao de troca, decorrem quatro tipos distintos de lógica sobre o objeto: a) a lógica das operações práticas, que corresponde ao valor de uso, predominante na era pré-industrial; b) a lógica da equivalência, correspondente ao valor de troca, característica da época industrial, momento em que a vida comunitária, sendo paulatinamente substituída pela vida citadina, impõe relações de troca entre grupos humanos; c) a lógica da ambivalência, que corresponde à troca simbólica, presente em todos os períodos históricos, mas acentuada na modernidade e no chamado capitalismo metafísico ${ }^{34}$ (Lash, 2007); e d) a lógica da diferença, associada ao valor do signo. Essas lógicas podem ser resumidas como as de

\footnotetext{
${ }^{34}$ Ver, na sequiência do texto, a discussão proposta por Lash (2008).
} 
utilidade, do mercado, do presente e do status, respectivamente, e associadas aos diferentes momentos da história humana. "Os estilos de vida e os valores - não a necessidade econômica - são a base da vida social" (Baudrillard, sem data, p. 261, grifos nossos).

Para esse autor, a era do código começa a penetrar todo o tecido social e um dos sintomas disso é que "os opostos começam a entrar em colapso e tudo se torna 'indecível': o bonito e o feio na moda, a esquerda e a direita na política, o verdadeiro e o falso na mídia, o útil e o inútil no [plano] dos objetos; [...] todos se tornam intercambiáveis na era da reprodução e da simulação" (Baudrillard, sem data, p. 262).

As proposições de Baudrillard agregam importantes elementos ao estudo da criatividade no contexto do mundo atual, uma vez que enfatizam a necessidade de diferenciação permanente, a importância dos estilos e a existência de uma economia simbólica, elementos esses, como se viu até aqui, relacionados à criatividade. $\mathrm{O}$ estudo das características da criatividade no universo atual das organizações será agora complementada pela diferenciação entre capitalismo físico e metafísico, proposta por Lash (2007).

\subsubsection{Capitalismo físico e capitalismo metafísico}

“A neo-commodity é um genótipo informacional agindo num algoritmo de mutações, em que apenas algumas conseguirão unir-se a um ambiente e alcançarão o status de fenótipo" (Lash, 2007, p.9). 
Para Lash (2007), a nova fase do capitalismo deveria receber a denominação de capitalismo metafísico, pois se, na definição clássica, a mercadoria física, os meios físicos de produção e a fisicalidade da força de trabalho eram unidos para produzir um produto físico, com a utilização intensiva da tecnologia, esta passou a atuar como uma segunda natureza, possibilitando a nova denominação para a fase atual do sistema capitalista.

Estas características atuais causam impactos na forma e no tempo do trabalho. Nas palavras do autor, "muito do trabalho no novo capitalismo tem lugar nos projetos e nas redes de projetos: aqui o tempo de trabalho é regulado pelo projeto em si, fazendo com que os cronômetros do capitalismo clássico tornem-se crescentemente irrelevantes". Revela-se uma nova relação com o tempo do trabalho, pois, se o tempo de trabalho no capitalismo físico seria qualitativo, métrico, extensivo e quantificável, no capitalismo metafísico, o tempo de trabalho também é quantitativo, mas não é mais métrico; passa a ser indivisível e intensivo. A questão do tempo do trabalho e do tempo no trabalho será retomada adiante quando será discutida a noção de tempo para a criação.

A análise de Lash aborda ainda a evolução do próprio conceito de matéria, que, em sua definição clássica é associado a um tempo de trabalho abstrato, homogêneo e congelado. Diferentemente de valor de uso e de troca, pois ambos têm a ver com propósito, esse valor-trabalho é o valor-substância da mercadoria. O valor de troca é questão de função, mais que de estrutura; não é interno à mercadoria, que é estruturalmente gerada pela sua substância, por seu valor-substância. $\mathrm{O}$ valor de troca tem a ver com propósito e necessidade; é a confirmação exterior da mercadoria por sua demanda ou oferta. No capitalismo metafísico, pode-se falar em valor estético, confirmando toda a valorização do design como função imprescindível aos processos produtivos atuais. 
Segundo Lash (2007), é possível identificar quatro contrastes entre o físico e o metafísico, a saber: extensão - intensidade; equivalência - inequivalência; equilíbrio - desequilíbrio; fenômeno - nômeno. Em todas elas, manifesta-se a questão do princípio da identidade ou da ontologia da diferença. Ao analisar o valor da marca no capitalismo atual, o autor aponta uma importante mudança na dinâmica atual da vida produtiva: se a mercadoria (commodity) é divisível em quantidades de valor de troca, a marca (brand), não é. No chamado capitalismo metafísico, fenômeno e nômeno se fundem. Ele exemplifica: a pesquisa não é mais só pesquisa: é $\mathrm{P} \& \mathrm{D}$ (pesquisa e desenvolvimento); a propriedade não é mais só propriedade: é propriedade intelectual. Com as questões abordadas por Lash, é fácil entender a complexidade do processo criativo incorporado às inovações e invenções discutidas no capítulo precedente.

Além de realçar a importância e a necessidade da criatividade no universo atual dos negócios, os problemas elencados por Thrift (2006), Baudrillard ([1973], 2000; [1981], 2005) e Lash (2007) apontam para o fato de que as pesquisas sobre inovação deverão buscar identificar o valor simbólico que porventura venham a agregar. E, uma vez que é a dimensão estética que promove a diferenciação com relação à funcionalidade de um objeto, o diferencial competitivo, a busca pelo ser diferente ou fazer a diferença guardarão necessariamente relação com a estética, mas é no valor simbólico que se revela toda a magnitude do objeto no momento histórico atual, assinalando a complexidade de qualquer análise sobre inovação.

Um dos exemplos mais emblemáticos do capitalismo metafísico é do telefone celular. Diferindo inicialmente do telefone convencional pela possibilidade de captação do sinal 
em ambientes distantes de uma base fixa, foi paulatinamente agregando novas funcionalidades, transformando-se em algo distinto do inicialmente planejado. Ou seja, o objeto em si já não é mais ele mesmo, mas transformou-se em outro (s), acoplando a si propriedades que estariam presentes em outros objetos, característica da criatividade enquanto objetivação e também como combinação de elementos. Atualmente, há aparelhos de telefonia celular que são simultaneamente câmaras fotográficas, câmaras de vídeo, despertadores, agendas, calendários e microcomputadores capazes de receber e enviar mensagens via Internet. Do ponto de vista de seu consumo, a aquisição desse objeto leva em consideração as inúmeras funcionalidades que ele potencializa e, por vezes, comprá-lo pode não ser determinado pelo sinal telefônico que ele oferece, mas pelos parâmetros de status, modelo ou qualidades a ele adicionadas. O valor simbólico e seu significado ultrapassam o objeto físico e seu consumo não mais se baseia em seu valor de uso, nem em seu valor de troca. Um telefone celular é símbolo e, simultaneamente, signo, carregando distintos significados. Não é mais o objeto físico que importa, mas a experiência que ele propicia, o design a ele incorporado e as qualidades que se colocam para além do sinal telefônico. De acordo com as categorias de contrastes propostas por Lash (2007) e expostas acima, pode-se afirmar que as mudanças introduzidas tornam o telefone celular mais extenso ao agregar as novas funções (extensão versus intensidade), inequivalente (equivalência - inequivalência) e mais equilibrado (equilíbrio desequilíbrio), além de incluí-lo dentre os objetos para os quais o contraste nômeno fenômeno perde o sentido, pois ambos fazem parte do mesmo objeto.

\subsubsection{Economia criativa e indústrias criativas.}


Surgido na Austrália, o termo indústrias criativas ganhou maior espaço na literatura da Inglaterra, em função de um levantamento detalhado sobre este tipo de indústria no país que classificou como setores criativos a publicidade, a arquitetura, o mercado de artes e antiguidades, o artesanato, o design e o design de moda, o cinema, os softwares em geral e os interativos para lazer, a música, as artes performáticas, a indústria editorial, o rádio, a TV, os museus, galerias e as atividades ligadas às tradições culturais (DCMS, 2005, citado por Bendassolli et al., 2009, p. 10). Em última instância, são indústrias cujo produto tangível depende da matéria-prima que é a criação humana. Outras definições atribuem o termo indústrias criativas ao fato de que seu principal insumo são as pessoas criativas. A distinção entre tais indústrias e as indústrias culturais, estudadas pela Escola de Frankfurt, poderia ser meramente semântica, como propõem Bendassolli et al. (2009), embora a crítica ao desaparecimento da aura a que se refere Walter Benjamin ${ }^{35}$ permaneça válida mesmo sob a nova nomenclatura.

Mesmo estas indústrias, caracterizadas pelo desenvolvimento contínuo (de produtos, processos e pessoas) e renovação permanente de propriedades intelectuais, na medida em que amadurecem (conforme o ciclo descrito anteriormente), tendem a se tornar mais direcionadas ao mercado, da mesma maneira que as indústrias manufatureiras (Tschang, 2007). A evolução de qualquer organização, para Tschang, leva cada vez mais a considerações sobre eficácia e, simultaneamente, à redução das preocupações com a inovação, à custa da criatividade (p. 989). Logo, o binômio racionalidade - criatividade $^{36}$, seja ele na indústria criativa, seja nos setores mais tradicionais da manufatura, tende a ser a questão central a enfrentar do ponto de vista da inovação. A racionalidade, definida a partir do foco predominante nos interesses e lucros de um negócio, a partir de processos

\footnotetext{
${ }^{35}$ Ver capítulo IV desta tese.

${ }^{36}$ A tensão racionalidade - criatividade é discutida mais adiante neste capítulo.
} 
orientados à produção e à produtividade, geralmente ocorre à custa da criatividade. Uma das expressões desse fenômeno são as restrições às descobertas serendípicas (Tschang, 2007, p. 990). O autor exemplifica com a indústria cinematográfica que, na busca de incremento de eficiência, utiliza-se de scripts cena-a-cena, constrangendo idéias que podem surgir de forma relâmpago durante essa produção.

A indústria de videogames é similar a todas as demais indústrias criativas, explica Tschang. Nela, a atividade dos (as) funcionários (as) _ que são chamados de desenvolvedores (as) _ envolve uma grande quantidade de pensamento criativo e os jogos devem satisfazer as expectativas de seus clientes. Nos estúdios se processa o trabalho criativo, que inclui o design e o desenvolvimento dos jogos, mas, se analisado sob a perspectiva desse setor industrial específico, há um isomorfosimo institucional que faz com que as organizações se assemelhem umas às outras (p. 1001). Há um comportamento que pode ser denominado isomorfismo mimético, em função das duas tendências contraditórias que devem ser atendidas simultaneamente, quais sejam, a novidade e a familiaridade, as motivações comerciais e as artísticas, a investigação e a exploração (em inglês, exploitative e explorative). Tais contradições são resolvidas, muitas vezes, pela criação de novas empresas que, ao nascer, conseguem dedicar-se ao novo (p. 1002) ou, dentro das organizações existentes, pela criatividade combinatória _ combinação de características de jogos do passado _ que pode resultar em inovações. Este último aspecto está em acordo com a proposição de Schumpeter que definia inovação como "novas combinações de conhecimento existente e aprendizagem incremental” (In: Tschang, 2007, p. 1002). No plano cognitivo, a criatividade combinatória está relacionada ao “construtivismo, filosofia de aprendizagem baseada na premissa de que [nosso] entendimento e representação do mundo reflete [nossas] experiências. Nos games, o 
construtivismo envolve a fertilização cruzada de idéias de jogos anteriores e outras mídias, incluindo livros e filmes" (p. 1002). A imagem da fertilização cruzada e da combinação de elementos de distintas mídias guarda consistência com a conceituação de criatividade como bissociação (Koestler) ou combinação de elementos (Boden, 1999).

Se o aspecto racionalidade - criatividade é comum às indústrias criativas e às tradicionais, um diferencial entre as duas é que as primeiras são muito mais dirigidas pela busca da novidade do que as outras. Entretanto, mesmo neste aspecto, diz Tschang que se os (as) consumidores (as) esperam novidades em seus produtos e mercadorias, eles também esperam que tais novidades possam ser familiares e acessíveis. Ou seja, espera-se que estas indústrias possam desempenhar uma quantidade significativa de pensamento criativo, mas, ao mesmo tempo, elas devem atender às expectativas de seus (suas) clientes.

O estudo de Tschang (2007), que foi realizado na indústria de videogames, exemplifica bem a existência permanente desta tensão. Constituída por três tipos de atores, a saber, os estúdios independentes, as editoras e os consumidores (as), é aos estúdios que fica reservado o trabalho de criação; são eles que desenham e desenvolvem os jogos. Mas o trabalho criativo sofre com as restrições impostas pelas racionalidades por parte das editoras e do público consumidor.

A influência das forças racionais na inovação incremental pode ser analisada pelas lentes do isomorfismo institucional ou as forças institucionais que obrigam as organizações a se assemelharem às outras (Tschang, 2007, p. 1001). Na indústria estudada por ele, estúdios e editoras fazem produtos cada vez mais similares e utilizam-se dos mesmos processos. Há também o isomorfismo mimético, devido às incertezas do ambiente, conceito que também 
ajuda a compreender o comportamento imitativo por parte dos estúdios. As práticas de benchmarking, comuns às organizações na modernidade, contribuem para este mimetismo, fazendo com que muitas organizações se pareçam com as outras e, no geral, tornem-se muito semelhantes. Outro aspecto identificado pelo autor em sua pesquisa foi a tendência a uma forma normativa de isomorfismo na profissionalização do setor. Este aspecto não será explorado neste estudo, mas caberia investigar se o mesmo ocorre em outros setores ou somente nas indústrias criativas.

Novidade e familiaridade são, portanto, os dois pólos opostos que dinamizam a inovação nas organizações. A pesquisa do novo tende a ocorrer lado a lado com o refinamento e a expansão das competências existentes. Investigar e pesquisar a novidade ou utilizar e refinar o existente? Como afirmava Schumpeter (In: Tschang, 2007), pensar a inovação envolve "novas combinações de conhecimentos existentes e aprendizagem incremental".

A solução deste dilema organizacional pode induzir à criação de novas empresas para pessoas ou grupos em busca de caminhos radicalmente inovadores, como em alguns casos estudados (vide capítulo V).

\subsubsection{Racionalidade versus criatividade}

À medida que as organizações evoluem, a inovação dá lugar a considerações sobre a eficiência. De acordo com estudiosos (as), "a taxa de inovação de produto é a mais alta na fase emergente [de uma] indústria" (Abernathy \& Utterback, 1978 In: Tschang, 2007). Analisando o ciclo de vida das empresas, (Anderson \& Tushman, 1990, In: Tschang, 
2007) identifica períodos em que certos designs dominantes são seguidos por variações em produtos que, por sua vez, são seguidos por novos designs dominantes.

Racionalidade é definida como a predominância do foco em interesses dos negócios ou processos de produção orientados à produtividade, em geral à custa da criatividade (Tschang, 2007, p. 989). Ela pode restringir práticas criativas como as descobertas serendípicas.

A influência das forças racionais na inovação incremental pode também ser vistas sob as lentes do isomorfismo institucional ou das forças institucionais que constrangem as organizações a se tornarem semelhantes umas às outras (p. 1001). Estúdios e editoras tendem a fazer produtos similares e até utilizar-se dos mesmos processos. Esse isomorfismo mimético, isto é, o "isomorfismo devido à incerteza do ambiente em torno", ajuda a explicar o comportamento imitativo identificado pelo autor em seu estudo. Acrescente-se a isso que a "tendência à profissionalização nesta indústria representa que uma forma normativa de isomorfismo pode estar ocorrendo (p. 1001).

\subsection{Questões específicas da criatividade no contexto organizacional}

A criatividade no ambiente do trabalho humano talvez seja um "sonho impossível", como afirma Collier (1997). Se, por um lado, o discurso atual enfatiza a necessidade de criar e os indivíduos criativos são considerados ativos fundamentais das organizações, por outro, as práticas recompensam o comportamento seguro e não aceitam o risco envolvido nos gestos criativos. O lado escuro deste discurso está ligado a encarar estes ativos organizacionais como perigos à manutenção do status quo. Como diz Collier, "um [a] 
subordinado [a] capaz de elaborar uma idéia é um subordinado [a] capaz de perceber que ele [ela] não tem nenhum particular motivo para ser um [a] subordinado [a], especialmente [desta particular organização]" (Collier, 1997, p. 97). As considerações de Collier remetem à discussão dos ambientes propícios à criatividade e, em especial, da cultura organizacional como fator-chave na determinação desta ambientação. A frase da autora será base da análise que se segue acerca desses fatores e permitirá estabelecer o quão distante ou próxima está a realidade - praticada - em relação a este sonho - idealizado ou teorizado.

Segundo a autora, os ambientes propícios à criatividade envolvem: a) respeito pelos "ambientes" internos aos indivíduos (sua subjetividade), b) qualidade de relações interpessoais no âmbito de grupos ou equipes de trabalho e c) receptividade ou neutralidade para com a produção dos grupos de trabalho (Collier, 1997, p. 107). Em decorrência destas características, o clima organizacional propício à criatividade deveria promover confiança interpessoal, aceitação de comportamentos e idéias desviantes, desejo de e qualidade do ouvir; espírito de cooperação, encorajamento para a expressão de idéias, confrontação aberta de conflitos, amigabilidade para com colegas, respeito pelos sentimentos do outro, ausência de defensividade e inclusão de todos os membros de um grupo (Collier, 1997, p. 108).

Ainda de acordo com ela, do ponto de vista da organização, deve haver: liberdade para experimentar novas idéias, baixo nível de supervisão, responsabilidade delegada, encorajamento à participação, metas de trabalho desafiadoras, provisão dos recursos necessários, tempo para esforços criativos, confiança manifesta nas pessoas, interação com aspectos externos à organização encorajada, feedback a qualquer tempo. A partir de um 
ambiente como este, as pessoas poderão desenvolver: a) curiosidade; b) habilidade para suspender o julgamento [das idéias]; c) otimismo; d) humor; e) abertura para idéias; f) persistência; g) autoconfiança; h) tolerância à ambigüidade; i) espontaneidade ou impulsividade; j) habilidade para usar a imaginação e l) habilidade de se concentrar em um problema (p. 107).

Se todos esses aspectos devem se fazer presentes para que se potencialize a emergência da criatividade, estariam as organizações atuais preparadas para promover ou favorecer a criação do novo ou mantém-se a tendência da gestão baseada nos modelos tayloristas?

\subsubsection{Estruturas flexíveis: um paradoxo?}

Estruturas são necessárias para garantir a regularidade, mas podem matar a criatividade. Seria possível sujeitá-las a redesenhos permanentemente? Em função de serem representações compartilhadas, espaços para autoralidade e subjetividade, elas também estarão determinadas pela aceitação ou rejeição ao novo. A flexibilidade organizacional defendida por inúmeros autores (as) como necessária à promoção da criatividade é sinônima de limites de tolerância amplos e constantemente ampliados. Mas essa flexibilidade é antônima à burocracia, presente na realidade e no imaginário das organizações.

A flexibilidade é necessária em função das crises hoje enfrentadas pelas organizações, que dizem respeito aos aspectos operacionais, funcionais e adaptativos, tais como: a) diferenças entre o trabalho prescrito e real, tornando inviável o controle pela regulagem externa; b) necessidade de rapidez na tomada de decisões, tornando a centralização 
inviável; e c) exigência de contínuo desenvolvimento pessoal, tornando inviável a execução do treinamento por meio de regras formais (Malvezzi, 2008, mimeo).

Se os negócios crescem em complexidade, diversidade, incertezas e ambigüidades e seus dirigentes carecem da compreensão de todos os aspectos do contexto, bem como da certeza do significado, do valor e do poder das informações de que dispõem e não podem garantir a eficácia de suas decisões, pode-se deduzir que essas novas contingências demandam maior flexibilidade das organizações, como, por exemplo, o trabalho em redes. A flexibilidade torna-se, então, um aspecto crucial para a eficácia das organizações atuais. Interessa, portanto, incluir aqui a análise de Georgsdottir \& Getz (2004) sobre o desenvolvimento da flexibilidade nas pessoas e nas organizações.

Flexibilidade é definida pelos autores como a "capacidade de mudança e adaptação a um ambiente desafiador" (p. 166) e também pode ser entendida como sinônimo das margens de liberdade permitidas pela estrutura. Pode ser adaptativa - quando os desafios estão presentes no ambiente - ou espontânea - uma preferência pela mudança sem que haja qualquer pressão externa. A partir destas definições, os autores iniciam a análise desses dois tipos de flexibilidade aplicada à cognição e personalidade, por um lado, e à flexibilidade na recepção de inovações, por outro, enfatizando a relação entre mudança, adaptação e inovação, características da gestão por projetos, como pano de fundo da análise. Vale ressaltar que a categorização de flexibilidade como resposta a demandas externas ou propensão interna assemelha-se às tipologias da criatividade propostas por Kaufmann (2004) e Unsworth (2001), descritas no capítulo II. 
A partir da representação de inovação como "os processos comportamentais e sociais envolvendo indivíduos, grupos ou organizações na busca de alcançar mudanças desejáveis e evitar as penalidades da inação" (West \& Richards, 1999, p. 45 In: Georgsdottir \& Getz, 2004), os autores desenvolvem a análise da flexibilidade como característica do (a) inovador (a) e da audiência (indivíduos ou grupos envolvidos com a avaliação da inovação).

As conclusões deste estudo apontam que "a flexibilidade permite [ao inovador] superar os impasses quando da resolução de problemas, ver os problemas de uma perspectiva que não havia sido notada antes e até mesmo identificar novos problemas para solucionar" (p. 173). Quanto à audiência para a inovação - envolvendo seu processo de avaliação - a necessidade de flexibilidade se evidencia em função de que esta precisa ser receptiva, dando oportunidade às idéias novas e não usuais, sendo capaz de ouvir e receber propostas de todo tipo de pessoas. A flexibilidade, no plano individual, pode ser desenvolvida por meio de alterações na organização do trabalho, mudanças na rigidez das atitudes ou via desenvolvimento da flexibilidade pessoal, para a qual os autores apresentam proposições. No plano da audiência para a inovação, a alteração deve ser na estrutura organizacional, nas mudanças das atitudes rígidas da gerência ou no desenvolvimento da flexibilidade gerencial.

Do ponto de vista da inovação e do incentivo à criatividade nas organizações, o primeiro ponto a destacar é, portanto, a necessidade de flexibilidade, seja do ponto de vista da estrutura organizacional propriamente dita, seja para a tomada de decisões que tenham impacto na estratégia dos negócios. 
Entretanto, a flexibilidade, tão necessária à configuração organizacional propiciadora da inovação, tem que enfrentar o já cristalizado modelo taylorista, rígido e controlador e servir de base a um novo modelo, ainda por definir. Nesse sentido, a inovação de produtos, processos e serviços - no que concerne a decisões e estratégias - deveria estar organicamente integrada à inovação organizacional, o que não se confirma na pesquisa empírica empreendida para efeito desta tese. O argumento de Collier sobre o sonho impossível seria, então, sustentável?

\subsubsection{A dinâmica propícia à criação}

A benção nasce na dádiva da água que encontra o potencial da semente e o desperta. (Nilton Bonder)

O capitalismo metafísico - era do design - traz consigo novas necessidades, tanto no plano do processo produtivo quanto na gestão. Questões ligadas à imagem e à marca ficam ladoa-lado em grau de importância com a funcionalidade e a integração. Se, como se viu anteriormente, a flexibilidade na organização conota dar espaço ou acomodar a subjetividade, esse elemento tem que ser incluído nas práticas de gestão. Como se verá adiante, o paradoxo organizacional atual diz respeito à necessidade de ambidestria, ou seja, administrar simultaneamente a inovação e, simultaneamente, manter a regularidade. Se a administração da inovação tem interfaces com a imagem organizacional (questão simbólica) e com sua identidade (sistema de significados), como potencializar e fertilizar o novo nesse contexto? 
O encontro entre um determinado potencial e um cenário que fertiliza é uma das imagens que propiciam a compreensão dos aspectos ambientais necessários à criação ${ }^{37}$. A atmosfera do ambiente favorecedor ou inibidor do processo criativo é discutida por Lapierre \& Giroux (2003). Utilizando-se de um instrumento denominado “Questionário de Clima Criativo", abordaram, em sua pesquisa, dez dimensões do clima organizacional associadas ao tema: desafio, liberdade, apoio à idéia, confiança / abertura, dinamismo / vitalidade, diversão / humor, debates, conflitos, correr risco, tempo da idéia, além dos aspectos ligados à liderança e à gestão do processo criativo, focados em seis dimensões, quais sejam: desafio, liberdade, características do trabalho em grupo, encorajamento por parte da supervisão e apoio da organização.

Ao considerar a perspectiva psicológica dos indivíduos na organização, os autores, baseados em outros trabalhos (Couger, 1995 In: Lapierre \& Giroux, 2003) argumentam que "propiciar aos empregados cursos de solução criativa de problemas é um dos melhores programas de aperfeiçoamento que uma organização pode esposar" (p. 12).

Esses mesmos autores enfatizam um ponto até então não mencionado neste trabalho, mas que merece destaque em função de sua importância. Trata-se da serendipidade, também tratada por Kao (1996) e Robinson \& Stern (1997). Dizem eles: "Para viver um momento serendipitoso, deve-se estar aberto a diversos estímulos”. [Assim], uma organização deve prover fontes, treinamento e informação não relacionados às áreas principais de interesse de seus empregados ${ }^{38}$ (p. 13).

\footnotetext{
${ }^{37}$ A imagem foi extraída do livro "O Sagrado", de Nilton Bonder. RJ, Ed. Rocco, 2007. Nele, a idéia de benção é explicada como a conjugação de possibilidades internas e externas (p. 45).

${ }^{38}$ Veja também, abaixo, o capítulo relativo ao tempo.
} 
Embora suas conclusões sejam mais direcionadas a empresas do ambiente de alta tecnologia, o estudo empírico conduzido por Lapierre \& Giroux (2003) tem o mérito maior de investigar as lacunas dos achados anteriores que pudessem combinar as perspectivas psicológicas e gerenciais acerca da criatividade.

Também Georsdottir \& Getz (2004), baseados em pesquisa realizada em organizações européias, apontam que as "abordagens elitistas, nas quais a criatividade era vista como um raro atributo de indivíduos excepcionais os quais deveriam ser identificados e cultivados pelas organizações" (p. 173) devem ser substituídas por outras que considerem a participação abrangente de todos os funcionários". Na referida pesquisa, os autores identificaram que $80 \%$ das inovações derivaram de iniciativas de empregados que ocupavam posições mais simples nas organizações e, "na média, tais inovações foram avaliadas como mais radicais que aquelas cuja iniciativa partiu de pessoas de $P \& D^{39}$, marketing e outras unidades organizacionais de elite" (p. 173).

A partir da proposição de um "Sistema de Gerenciamento de Idéias", estes autores concluem que "ao invés de ter pessoas lidando com inovação em alguns lugares, todo mundo, qualquer que seja seu trabalho ou posição, está produzindo idéias que são prontamente avaliadas e implementadas. Além disso, ao invés de pessoas inovando apenas em áreas específicas e pré-determinadas, a inovação está ocorrendo em todos os domínios úteis para a organização" (p. 173).

Vale ressaltar que, quando se enfoca a criatividade a partir de seu processo, não cabe ressaltar os bloqueios individuais que podem emperrar o seu bom desenvolvimento; tornase imperativo apontar os elementos sociológicos e políticos que podem interferir

\footnotetext{
${ }^{39}$ P\&D: abreviatura utilizada para a área de pesquisa e desenvolvimento.
} 
negativamente. Assim, o elenco de características componentes de um ambiente propício à criatividade no interior das organizações é um elemento-chave na presente análise, confirmando, mais uma vez, a afirmação de Collier sobre o sonho - talvez - impossível.

\subsubsection{Avaliação e erro nas organizações}

Quanto tempo levou a humanidade para aceitar que a Terra é redonda?

(Neilson, Louise. Mediating with Picasso)

Ao questionar as causas dos insucessos e fracassos de idéias criativas, Mumford et al. (2006) constatam que não bastam esforços e capacidades para assegurar sua consecução. Exemplificam que Thomas Edison, um inventor inquestionável, falhou ao tentar desenvolver o telefone; que a empresa Xerox, embora tenha desenvolvido o primeiro protótipo do computador pessoal, não conseguiu implementar esta tecnologia e que também Andy Warhol teve "fracassos abismais" com seus filmes (Mumford et al., 2006, p. 75).

Segundo Mumford et al. (2006), nem todos os problemas demandam pensamento criativo. Problemas criativos são aqueles que requerem novas soluções, ou, pelo menos, soluções que sejam novas para o indivíduo, contendo as seguintes características: a) tendem a ser mal definidos (não são aparentes os elementos e a estrutura); b) tendem a ser complexos (envolvem múltiplas peças de informação e múltiplas ações de processamento); e c) são, por natureza, dinâmicos, com soluções desdobrando-se no tempo. 
Dadas as características de complexidade, dinamismo e falta de definição, tais problemas envolvem alto grau de incerteza, gerando, por isso, muitos caminhos viáveis. Logo, há decisões a tomar; decisões sob incerteza, apresentando inúmeras similaridades com o momento atual, descrito no capítulo I desta tese.

Os autores analisam muitos dos vieses cognitivos que podem induzir a erros ao longo das etapas que caracterizam o processo criativo. Baseados nas mesmas questões da teoria desenvolvida por Tverski e Kahneman (1988), discutem os vieses que podem levar a erros no caso específico do ambiente criativo. Inicialmente, apontam para as etapas do processo criativo (p. 78), a saber: a) construção do problema; b) coleta de informações; c) seleção de conceitos; d) combinação conceitual; e) geração de idéias; f) avaliação de idéias; g) plano de implementação e h) monitoramento. A cada uma das etapas corresponderia determinado tipo de viés e, consequentemente, a tendência a um tipo particular de erro.

As análises sobre os erros que a seguir são apresentadas provêm de estudos experimentais e também de estudos históricos sobre inovações tecnológicas notáveis, realizados por estes autores. Os erros relativos aos fenômenos de interação social, como o pensamento grupal, a pressão para a conformidade e a chamada vagabundagem social, não foram analisados por eles.

Inicialmente, esclarecem que os erros podem ocorrer (ou ser induzidos) por mecanismos conscientes e inconscientes, associacionais, coleta ou armazenamento de informação. Por exemplo, pesquisadores (as) tendem a se basear mais em fontes locais verbais de informação do que em fontes como artigos de jornal, encontros profissionais e benchmarking. O viés aqui utilizado é denominado informação disponível. 
Por sua vez, a familiaridade e o comprometimento com um determinado modelo mental podem levar o indivíduo a ignorar coisas que não se encaixam nestes modelos. Especialistas, em geral, têm à disposição muitas categorias para organizar e entender os eventos em determinado domínio, muitas estruturas exemplares. A expertise traz consigo estruturas de conhecimento pré-existentes e, embora conhecimento e expertise sejam necessários para o pensamento criativo, há um ponto a partir do qual não contribuem para tal. Protocolos de uso freqüente, bastante acessíveis aos mais experientes, podem levar a pessoa a ignorar ou descontar aspectos únicos do problema. Além disso, a expertise leva à formação de crenças sobre causas e relações entre eventos. A fixação em determinado tipo de raciocínio parece dificultar a solução de novos problemas, uma vez que não enfoca os dados atuais do problema.

Com respeito à informação, eventuais dicas na situação-problema tendem a ativar associações freqüentes e recentes e podem bloquear outros caminhos de informação que poderiam levar ao novo.

Outros vieses tratados pelos autores referem-se a estratégias de simplificação, a saber, representatividade, correlação ilusória e ancoragem (p. 86). Quando categorias ou conceitos são definidos por casos exemplares, estruturados a partir de certas características, a tendência é ater-se aos atributos mundanos, de fácil acesso do conceito, o que reduz a chance de novas características emergirem em combinações conceituais. Tal processo é denominado viés da representatividade. 
Com relação ao viés relativo às muitas categorias organizadas por meio de múltiplas características, explicam os autores que quando um objeto ou evento é designado para uma determinada categoria, isso ocorre mesmo que essas características não sejam evidentes no caso em questão (correlação ilusória) (p. 87).

No que concerne à ancoragem, tem-se um estímulo ou conceito inicial que é selecionado para avaliar o problema em questão e definir os parâmetros da solução e essas âncoras são ajustadas à medida que novas informações se tornam disponíveis, mas tais ajustes são feitos muito lentamente. A persistência na âncora pode levar a um caminho inefetivo.

Um dos vieses mais relevantes do ponto de vista deste estudo é o da aversão ao risco. Uma vez que os problemas criativos demandam soluções novas para problemas pouco estruturados, o risco estará necessariamente presente e os estudos demonstram que há uma correlação entre o envolvimento com a solução criativa de problemas e a disposição ou propensão à tomada de risco. Paradoxalmente, há uma aversão ao risco e as estratégias para gerenciar o risco durante o processo criativo podem induzir a erros. Este tipo de viés e possível erro foi identificado especialmente na fase de avaliação de idéias, a partir da tendência a avaliar e rejeitar idéias que impliquem risco excessivo (ou indevido), particularmente naquilo que se refere a resultados, podendo envolver a percepção de perdas ou prejuízos financeiros. A aversão ao risco pode também se manifestar na relutância em tomar decisões ou comprometer-se com um determinado curso de ação e, neste momento, o evitar se comprometer com um curso de ação pode induzir a erro e ser especialmente complicado quando se precisa persistir mesmo que tenha havido fracasso inicial. A própria coleta de informações (dados) para resolver um determinado problema pode ser uma estratégia para a redução dos riscos e, assim, levar a erros. Um experimento 
de tomada de decisões em situação de pressão de tempo revelou que as pessoas se engajavam em verificar mais de uma vez as informações disponíveis, usando o tempo para isso e não investindo em combinações conceituais ou geração de idéias (p. 90).

Uma outra estratégia para reduzir o risco que pode induzir ao erro é a consideração dos atributos gerais das alternativas ao problema. Um experimento descrito por Mumford et al. (2006) sobre tomada de decisão envolvendo o aluguel de um apartamento descrevia as vantagens e desvantagens gerais de cada imóvel, incluindo os melhores e piores atributos de cada um. Como resultado, os sujeitos que, além da consideração pelos dados gerais do problema, decompuseram analiticamente cada alternativa, tiveram melhores resultados.

Outro fator relacionado ao erro é a tendência ao otimismo. Os autores alertam para a existência de uma tensão entre a aversão ao risco e o otimismo. O excesso de otimismo diante do novo ou a excessiva confiança nas idéias e abordagens anteriormente comprovadas pode induzir ao erro. Exemplo disso seria o erro de estimativa, a falha na avaliação acurada do tempo e dos recursos necessários para completar um trabalho (p. 92). A tendência, num experimento realizado com alunos de graduação, foi subestimar o tempo necessário para completar as tarefas acadêmicas, em função de desconsiderar os vários impedimentos que poderiam advir quando se começa o trabalho.

Uma vez que as ações criativas baseiam-se em linhas de menor probabilidade e existem inúmeras dificuldades relativas à percepção do novo pelo ser humano e à originalidade desses atos, a problemática da avaliação dos produtos criativos está sujeita a inúmeros vieses e erros. Seja na produção acadêmica, em que prevalece o julgamento pelos pares, seja na seleção de empresas para incubação, seja nos pareceres que são emitidos por 
revistas especializadas para inclusão ou não de artigos ou ainda na avaliação de trabalhos científicos inscritos em congressos, é fato que esta problemática está presente.

Para Drucker, a inovação necessita práticas específicas quanto à estrutura organizacional, provisão de pessoal e gerência, remuneração, incentivos e recompensas. Tais práticas compreendem a remoção ou redução de obstáculos. Além disso, deve-se delinear relacionamentos baseados em empreendedorismo e assegurar que seja recompensado e não punido o comportamento empreendedor (intraempreendedor). $\mathrm{O}$ autor sugere organizar separadamente a gestão da inovação da gestão da rotina do negócio, pois "o novo parece insignificante, pouco promissor diante da segurança do negócio em andamento e [há] a tentação de adiar ações empreendedoras ou inovadoras até que seja tarde demais" (Drucker, 1985, p. 225). Atribuir uma posição especial para a nova iniciativa na organização é a solução proposta pelo autor.

Ainda há um elemento a analisar quanto à problemática da avaliação e do erro. Diz ele respeito às inúmeras formas de premiação da criatividade humana que foram instituídas ao longo do século XX, tais como o Prêmio Nobel, na ciência e na paz; o Grammy, na música, e o Oscar ${ }^{40}$, no cinema, apenas para mencionar alguns. No caso do empreendedorismo e de negócios inovadores no Brasil, destacam-se o Prêmio ANPROTEC $^{41}$ e o Prêmio FINEP ${ }^{42}$ de Inovação.

A história do Prêmio Nobel é bastante ilustrativa e emblemática sobre as premiações. Alfred Nobel, em seu testamento, manifestou expressamente o desejo de recompensar a criatividade humana e, para isso, criou um fundo que premiasse boas idéias (Barlach,

\footnotetext{
${ }^{40}$ Movie Academy Awards, popularmente denominado Oscar do cinema.

${ }^{41}$ Associação Nacional de Entidades Promotoras de Empreendimentos Inovadores.

${ }^{42}$ Financiadora de Estudos e Projetos.
} 
2008). Ser laureado (a) com o Nobel é fator distintivo de reconhecimento de uma obra criativa e padrão de excelência que indivíduos buscam atingir. No entanto, nem todo ato criativo recebe este tipo de reconhecimento. Outros sofrem dos vieses cognitivos discutidos, tornando problemática a avaliação de seus respectivos objetos, causando desconfortos a pessoas criativas, que podem ter atos criativos preteridos ou ignorados.

\subsubsection{A cultura organizacional e o efeito Einstellung}

No contexto organizacional, a presença de modelos e comportamentos arraigados pode ser detrimental com relação a processos inovadores. Um dos aspectos mais paradoxais deste fenômeno diz respeito ao fato de que, se a cultura organizacional reforça os elementos que foram bem sucedidos ao longo de sua história ${ }^{43}$, transformando-os em rituais, crenças, valores ou símbolos, este mesmo aspecto pode ser impeditivo para enxergar o novo. Assim, as premissas básicas de uma cultura podem - ou não - estimular a criatividade dos indivíduos, sendo os fatores mais relevantes para a caracterização de uma cultura inovadora: um alto grau de flexibilidade, a busca da melhoria contínua e o olhar para o futuro.

Assim, a própria definição de cultura dá lugar à reflexão sobre a armadilha do sucesso comentada por Kaufmann, pois ela é a representante do passado na organização, daquilo que foi assumido como legítimo, consistente ou eficaz. Nesse sentido, pode-se considerar paradoxal a consideração de uma cultura organizacional inovadora, como faz Shyniashiki (2004), tendo como base o modelo de Quin e Cameron. Caracterizada por um alto grau de

\footnotetext{
43 A cultura é formada pelo conjunto de pressupostos básicos que um grupo inventou, descobriu ou desenvolveu ao aprender a lidar com problemas / desafios de adaptação externa e integração interna e que funcionaram bem o suficiente para serem considerados válidos e ensinados a novos membros como a forma correta de perceber, pensar e sentir com relação a estes problemas (Schein, 2004).
} 
flexibilidade, a busca da melhoria contínua e o olhar para o futuro, além de convívio com a incerteza e as rupturas, a cultura inovadora de uma organização ou a cultura de uma organização inovadora precisaria de sua antítese para se afirmar como inovadora.

O paradoxo cultura - inovação nas organizações pode ser compreendido a partir do chamado efeito Einstellung (Kaufmann, 2004). As pesquisas que o identificaram basearam-se no seguinte: 1) Indivíduos resolvem uma série de problemas de acordo com determinada fórmula; 2) a seguir, [esses indivíduos] são confrontados com uma tarefa ligeiramente desviante que pode ser solucionada de acordo com a velha fórmula, mas pode mais facilmente ser resolvida por meio de nova fórmula. [Um grande número de participantes nestes experimentos continuou a usar a velha e complicada fórmula, ao invés da nova, mais conveniente]; 3) um novo problema é apresentado que não pode ser resolvido com a fórmula padrão, mas é facilmente solucionado por meio de uma fórmula nova e simples. [Resultados mostram que um surpreendentemente grande número de pessoas não consegue resolver este problema simples em função da necessidade de acomodações na busca da solução].

A questão do efeito Einstellung remete à armadilha do sucesso nas organizações (Kaufmann, 2004), à valorização daquilo que deu certo no passado como predominante nas culturas organizacionais e as dificuldades para "pensar fora da caixa", na terminologia de Bono (1990).

O moderno discurso social e organizacional enfatiza a necessidade de inovar, de buscar o novo, em quase todos os campos de conhecimento e ação social. Fala-se muito acerca da necessidade de inovação nas organizações (e também das organizações) tratando esta 
necessidade como um imperativo do tipo "Inovar ou morrer" (Jeanes, 2006, p. 127) ou como um "mantra" (Jeanes, 2006, p. 127; Plonski, 2006 ${ }^{44}$ ). Entretanto, muitos indivíduos que buscam a inovação internamente às organizações ainda enfrentam a rejeição de seus projetos devido a obstáculos de ordem cultural e política, como nos casos que serão descritos no presente estudo.

\subsubsection{Ambidestria organizacional: investigação do novo e utilização do consagrado}

Em ambientes marcados pela dinâmica da mudança constante, as organizações precisam de capacidades de integrar, construir e reconfigurar recursos e competências para alcançar a inovação contínua. A exploração de novas idéias, tecnologias e conhecimentos, por um lado, e, por outro, a utilização (ou integração) do conhecimento existente é essencial para um processo bem sucedido de inovação. Organizações precisam decidir quão bem alocar seus escassos recursos para ambas as atividades e, ao mesmo tempo, construir capacitações dinâmicas que possam mantê-las atualizadas com relação às condições de mercado, o que, por sua vez, é influenciado pela capacidade de assimilar conhecimentos de cada organização (Soosay \& Hyland, 2008, p. 20).

“A essência da empresa inovadora é sua habilidade de se adaptar às mudanças do mercado, influenciada pela integração organizacional de uma base de habilidades e da velocidade na qual novas competências e habilidades são desenvolvidas para atender às demandas das novas tecnologias" (Harryson et al., 2008, p. 746) O lócus da inovação estará em redes e não mais em empresas individuais, pois a habilidade de identificar e incorporar idéias e tecnologias externas aumenta a flexibilidade da empresa para responder às necessidades mutáveis dos (as) consumidores (as) (Harryson et al., 2008, p. 747).

\footnotetext{
44 “A inovação é um dos mantras das sociedades contemporâneas” (Plonski, 2004).
} 
Sobre a tensão entre a utilização, refinamento e expansão das competências existentes versus a investigação de novas possibilidades, Tscahng (2007) acrescenta que elas envolvem indiretamente a necessidade de novidade e de familiaridade por parte de futuros usuários. Embora o autor também enfatize a necessidade da ambidestria organizacional para enfrentar tal dilema, ele observa que a solução desta tensão muitas vezes envolve a criação de novas empresas que se dedicarão às novas criações.

\subsection{Criatividade e empreendedorismo}

Drucker (1985) analisa o avanço do empreendedorismo no mundo a partir de dados da evolução da economia americana que, até meados dos anos 1970 concentrava-se nas instituições que já eram grandes - as [chamadas] 500 da Fortune, incluindo as maiores empresas, os governos federais, estaduais e municipais, as universidades grandes e supergrandes, as grandes escolas secundárias, o grande hospital [...] "Tais instituições criaram praticamente todos os empregos existentes na economia americana no quarto de século depois da segunda guerra mundial" (Drucker, 1985, p. 1). A partir de então, slogans como "economia crescimento zero", "desendustrialização", tornaram-se axiomas, indicando um redirecionamento profundo da economia, de gerencial para empreendedora. Segundo o mesmo autor, as 500 empresas da lista da revista Fortune apresentaram queda em vendas e lucros e acarretaram perda de empregos, ao passo que empresas pequenas e médias não só geraram empregos, como tiveram boa taxa de crescimento.

Mas é necessário relevar que "nem todos os pequenos negócios novos são empreendedores" (Drucker, 1985, p. 28). Para ele, a rede de fast food McDonald’s é um 
caso de empreendimento, mas não houve invenção alguma uma vez que seu produto final já vinha sendo produzido há muitos anos. Há, neste caso, inovação, pois, ao aplicar conceitos de administração e técnicas gerenciais (perguntando o que é valor para o consumidor), padronizando o produto, desenhando processos e equipamentos, baseando o treinamento de seu pessoal na análise do trabalho a ser feito e a partir daí estabelecendo os padrões de qualidade que exigiria, não somente elevou drasticamente o rendimento dos recursos como criou novo mercado e novo consumidor. Isso é empreendimento.

Todas as pequenas empresas novas têm muitos pontos em comum. Entretanto, para ser empreendedora, uma empresa tem que possuir características especiais, além de ser nova e pequena. Empreendimentos constituem a minoria dentre as pequenas empresas. Para considerá-los empreendimentos, deve estar presente a criação de algo novo, diferente; o mudar ou transformar valores (Drucker, 1985, p. 29).

A possibilidade de empreender não fica restrita aos pequenos negócios. Em função desta definição, também velhas e grandes empresas podem praticar o empreendedorismo. E este, por sua vez, não fica restrito a instituições econômicas, pois há que se considerar mudanças sociais e culturais (p. 30). Exemplos de inovações "não-técnicas" são o jornal, o seguro e as compras a prazo. A mudança inserida na economia diz respeito ao fato de que esta não é mais dirigida pela oferta, mas pela procura.

Como se viu até aqui, criatividade, inovação e empreendedorismo compartilham significados. Drucker (1985, p. 35) frisa que "empreender é fazer diferentemente e não fazer melhor o que vem sendo feito". Nesta definição, a criatividade representa o pólo do 
fazer diferente, dependendo do empreendedorismo para se viabilizar e explicita-se o que não é, necessariamente, inovação, a saber, melhorar algo que já vem sendo praticado.

\subsubsection{Criação de empresas e empreendedorismo inovador}

Se há um "mercado de idéias" similar ao mercado de ações, como propõem Sternberg et al (1997), o empreendedorismo inovador tem sido um dos beneficiados pelos investimentos recebidos, seja em capital de risco, seja na incubação destes empreendimentos.

O termo empreendedorismo inovador poderia ser considerado um pleonasmo em face da conceituação de Drucker (1985) mencionada no capítulo III, que afirma que "a inovação é a função específica do [a] empreendedor [a]... é o meio pelo qual ele [ela] cria novos recursos produtivos de riqueza ou dota os recursos existentes de potencial aumentado para criar riqueza" (p. 37). Haveria, então, algum tipo de empreendedorismo que não fosse inovador? A resposta à questão é complexa, pois, embora inúmeros sejam os empreendimentos que não inovam, em cada novo empreendimento há um elemento novo que é introduzido, mesmo que este seja mais próximo do conceito de novidade apresentado no capítulo II, em que não há mudança, mas variação, ênfase de um - ou outro - elemento pré-existente. O fato de nem todos os empreendimentos serem inovadores pode ser facilmente comprovado pelo fato de que o órgão governamental brasileiro de apoio ao empreendedorismo, o $\mathrm{SEBRAE}^{45}$, tem uma divisão específica para a inovação, entendendo que a grande maioria dos novos negócios é convencional, e também justifica a existência da ANPROTEC, instituição brasileira voltada especificamente para o apoio a empreendimentos inovadores.

\footnotetext{
${ }^{45}$ Serviço Brasileiro de Apoio às Micro e Pequenas Empresas.
} 


\subsubsection{Incubação de empresas}

Em março de 2008, o Brasil contava com quase 400 incubadoras de empresas (Oliveira e Marques, 2008, p.69). Locais de "gestação do novo" ou "nascedouro de negócios", as incubadoras cumprem o papel de reverter o quadro de baixa inclinação da indústria brasileira à inovação. A grande maioria das incubadoras brasileiras tem vínculos com alguma instituição de ensino ou instituto de pesquisa, estabelecendo, assim, as bases para que as criações ali gestadas possam se apresentar ao mercado de potenciais usuários dos produtos, serviços ou processos desenvolvidos. Nas incubadoras, a relação universidadeempresa permite visualizar a tensão criação - mercado, mencionada anteriormente, especialmente no momento em que os negócios nascentes têm que buscar investidores (as) ou capital de risco. Em uma das entrevistas realizadas ao longo da elaboração desta tese ${ }^{46}$, a entrevistada relatava seu temor de que, ao se apresentar aos futuros sócios-capitalistas, sua idéia fosse "roubada" ou, em outras palavras, que seu projeto fosse apropriado pelo capital que desenvolveria o "seu" projeto de forma autônoma e diferente de sua proposta original. Essa empreendedora, embora tivesse patenteado sua invenção, receava que o caminho entre a invenção e a inovação pudesse ser desviado por interesses econômicos que se apropriassem do projeto.

A criação de incubadoras de empresas que, no Brasil, tem início no final da década de 1980, talvez possa ser explicada em função do fato de que, em sua fase nascente, as empresas são mais inovadoras e a incubação pode trazer inúmeros benefícios para viabilizar os projetos criativos e reduzir a taxa de mortalidade (Plonski, 2008). Esse apoio institucional a empreendedores é um recurso já consolidado e freqüente na realidade brasileira.

\footnotetext{
${ }^{46}$ Ver capítulo VI desta tese.
} 


\subsection{Ambidestría individual}

Fazer bem feito, fazer com esmero (para além da eficiência) $e$ não somente aquilo que não pode deixar de ser feito [um aforismo].

No capitalismo metafísico, seja no cotidiano, seja no trabalho organizado, a criatividade se faz presente em função da ambiência de incerteza, ausência de modelos ou falência de outros. Em função de seu poder de introduzir aquilo que é diferente, original, novo, a criatividade é ferramenta para a introdução das inovações tão necessárias para a competitividade atual.

As organizações enfrentam muitos tipos de obstáculos ao novo: estruturas burocráticas ou excessivamente hierarquizadas, culturas que cristalizaram valores e crenças do passado, necessidade de monitoramento permanente de seu ambiente (não sendo compatível com modelos de gestão focados apenas nos aspectos internos da organização), demandas específicas de mudanças no processo de produção pela consideração do imperativo do design, além de questões jurídicas ligadas a patentes. A problemática da avaliação e do erro, discutida no presente capítulo, introduz o assunto que se tratará no capítulo seguinte, a saber, o fato de que determinadas políticas internas às organizações podem impedir a viabilização de projetos potencialmente inovadores, sendo fonte de frustração para indivíduos que os abraçavam e que, em função disso, decidem empreender negócios próprios.

Os aspectos históricos, culturais e políticos envolvidos com as questões da criatividade e da inovação ficam flagrantes quando se analisam afirmações como: "Não há nenhum propósito em alguém ter um computador em sua casa" (K. Olsen, presidente da empresa 
Digital, 1977) ou "Que uso pode ter esse brinquedo elétrico?" (W. Orton, presidente da Western Union, rejeitando pagar US\$ 100.000 pelo invento de Graham Bell). A necessidade de enfrentar preconceitos e estereótipos sociais, seja na "introdução de um novo bem, cujos consumidores ainda não estejam familiarizados, seja na introdução de um novo método de produção e que tenha sido gerado a partir de uma descoberta científica ou ainda na abertura de um novo mercado em que uma área específica da indústria não tenha penetrado, independente do mercado existir antes ou não" (Schumpeter, 1934), é outra questão relevante nas pesquisas sobre a criatividade no universo dos negócios. Em outras palavras, a temática do reconhecimento, de fato, é mais complexa no interior das organizações.

Embora o discurso da inovação esteja cada vez mais presente, inúmeros obstáculos ainda se fazem marcantes nas organizações, tais como a postura conservadora, a intolerância quanto a riscos e fracassos, a falta de liberdade para funcionários (as) desenvolverem seus próprios projetos, a falta de patrocinadores internos e os rígidos sistemas de controle, dentre outros.

O modelo gerencial proposto por Taylor, Fayol e outros teóricos da escola de administração científica cristalizou-se nas organizações ao longo do século XX. Nele, a busca da eficácia, do controle e da previsibilidade não favorece o novo. O capitalismo da inovação - ou capitalismo metafísico -, demanda sensibilidade, espaço para a perfeição interna ao invés da ênfase plena com relação ao mercado, como ocorre com o elemento estético do design, que introduz inúmeras questões antes restritas ao universo artístico que devem ser gerenciadas por organizações em que ainda prevalecem os velhos modelos de gestão. 
É importante frisar que a ambiência mencionada traz consequiências na carreira dos indivíduos: “À medida que as organizações tornam-se menos estruturadas e menos planejadas, a chance dos indivíduos serem criativos na construção de suas carreiras é aumentada" (Peiperl et al., 2002, p.29). Há menos scripts pré-elaborados e mais oportunidades de improvisação e esta situação proporciona não só ameaças, mas oportunidades de crescimento e afirmação da autenticidade (Baxter, 1982). Lembrando que: a) auto-realização não tem relação necessária com aumento de produtividade (p. 174), b) “a existência autêntica nem sempre é possível no contexto organizacional” (p. 175), c) competência não se confunde com eficiência (p. 183), Baxter (1982) conclui que "embora o atual sistema de trabalho ainda seja baseado na alienação do self da pessoa em relação ao outro da organização47, existe nos parâmetros organizacionais espaço suficiente para o indivíduo criticamente consciente avaliar que, enquanto seus esforços para alcançar a auto-realização no trabalho podem levar a uma super-dependência das estruturas e metas da organização, [...], eles podem também levar à emergência de uma força interior ou coragem ontológica do ser que, por sua vez, servem como um trampolim para sua participação em uma forma de trabalho que não tem origem na alienação para com um outro" (Baxter, 1982, p. 185). A autenticidade do eu [self] demanda, por vezes, a ruptura com o outro [organização]. Há uma ambidestría individual que obriga o sujeito a gerenciar simultaneamente sua criatividade [self] e restrições do outro [organização, por exemplo]. Os casos discutidos no capítulo seguinte ilustram este processo.

\footnotetext{
${ }^{47}$ A análise de Baxter (1982) sobre alienação / estranhamento ou autenticidade / auto-realização está baseada na relação eu - outro, sendo o outro, a organização. Tal como Martin Buber, em seus estudos sobre a intersubjetividade [eu - tu], Baxter também conclui que, nesta relação, pode haver encontro ou desencontro, diálogo ou surdez.
} 
Capítulo VI 


\section{Do intraempreendedorismo criativo ao empreendedorismo inovador}

Mesmo tendo empreendido as análises anteriores, o apoio de dados empíricos esclarece melhor como se manifestam as categorias de análise em casos concretos. Sem pretender qualquer generalização ou representatividade estatística, realizou-se uma pesquisa qualitativa com pessoas que criaram seu próprio negócio, manifestando de forma aplicada idéias e projetos inovadores. Foi possível realizar a pesquisa com pessoas em processo de viabilização de seus projetos, vinculadas a incubadoras de empresas, que apóiam empreendimentos inovadores.

A cultura organizacional com forte ênfase na conformidade, a dificuldade de gerenciar de forma ambidestra a organização e a cegueira dos agentes do reconhecimento quando diante de projetos potencialmente inovadores são três dos fatores que se revelaram como obstacularizadores à criatividade nas organizações. Por outro lado, a causalidade pessoal revelou-se como a força vital propulsora para a continuidade das pessoas entrevistadas no sentido de dar continuidade a seus projetos na qualidade de empreendedores.

O objetivo deste capítulo é descrever a pesquisa empírica empreendida; nele são analisados e discutidos os resultados, à luz da revisão teórica.

\subsection{Descrição da pesquisa empírica}

Foi planejada a produção de dados empíricos, visando o apoio às análises anteriormente efetuadas, com o objetivo de compreender a criatividade no ambiente organizacional, incluindo o trabalho criativo, o indivíduo criativo nesse contexto, incluindo as empresas 
que promovem a criatividade e a inovação e o empreendedorismo sob a forma de criação de empresas ou projetos inovadores. Os dados teóricos subsidiaram a arquitetura de narrativas elaboradas por inovadores (as) - empreendedores (as) em situação de entrevista. Essa estratégia foi considerada mais adequada do que o uso de questionários porque estes poderiam não apreender a dinâmica e todas as variáveis implicadas em cada caso. Igualmente não foi escolhida a observação devido ao tempo que esta tática demandaria. Além disso, as narrativas são situações que podem ser analisadas a partir das categorias e problemas considerados na análise teórica descrita nos capítulos anteriores.

\subsection{A estratégia}

A estratégia para a realização deste estudo consistiu na investigação da narrativa como o dado empírico que revela a história de cada um dos sujeitos. Nela seria apreciada a experiência criativa, o desejo de realização na empresa onde cada um se encontrava, as dificuldades e a ação empreendida. A expectativa idealizada era de que cada caso pudesse conter a representação de todas as etapas do processo criativo que leva ao empreendedorismo inovador. A pressuposição norteadora dessa estratégia foi a produção de narrativas que revelassem o processo inovador-criativo em todos os seus elementos e etapas. Por meio das narrativas, seria possível analisar os dados e informações sobre o processo de interação entre o universo organizacional e os atos criativos. Reproduzem-se, nas narrativas, a relação entre a empresa e sua busca por inovação e a participação da pessoa nesse processo. 
Com iniciativas intraempreendedoras, essas pessoas tiveram tais idéias rejeitadas pelas organizações nas quais trabalhavam e, a partir daí, envidaram esforços para criar a sua própria empresa e desenvolver seu próprio projeto.

\subsection{Método}

Tendo em vista que a criatividade é um objeto que não pode ser reduzido a itens, o estudo de caso se impôs como caminho para permitir a apreensão do maior número de aspetos do problema. Observações ou questionários não seriam apropriados para captar a totalidade dos aspectos pertinentes a este estudo. Optou-se, portanto, pela realização de entrevistas semi-dirigidas, que possibilitassem a sujeitos elaborarem narrativas sobre suas experiências empreendedoras, expondo a textura de causalidades nas quais estas estiveram implicadas. A questão básica dessa metodologia era buscar (descobrir) padrões e situações que se replicam em diferentes experiências inovadoras - empreendedoras.

\subsection{População}

Foram buscados, como sujeitos da pesquisa, profissionais que passaram por alguma experiência recente de empreendedorismo-inovador em algum novo negócio a partir de uma idéia ou projeto criado por eles mesmos. Pressupunha-se que a vivência de criação de um empreendimento fosse uma das condições que possibilitariam a elaboração de narrativas. A expectativa idealizada era de que os sujeitos tivessem uma carreira em empresas nas quais se encontravam claros sinais de empreendedorismo interno e, que posteriormente, tivessem criado sua própria empresa para poder realizar projetos que não foram aceitos nas empresas que os contratavam. Na prática, esse critério de escolha dos 
sujeitos foi afunilado para pessoas que eram proprietárias de empresas incubadas num centro incubador da cidade de São Paulo e outras que foram por elas indicadas.

Não houve busca de representatividade neste estudo com relação às organizações como um todo e tampouco foi adotado um critério amostral. O objetivo foi observar a condição criativa nas organizações e sua trajetória, passando pela inovação e pelo empreendedorismo para compreender como esses elementos se integram. Dentro desses critérios, foram buscados empreendedores-inovadores em diversos lugares, tais como incubadoras de empresas e redes de inovação. Os sujeitos escolhidos para este estudo foram identificados a partir de pré-entrevistas com diversas pessoas do universo dos negócios nascentes e solicitado a elas que indicassem casos de projetos de desenvolvimento de idéias criativas. Depois de consultas e conversas diversas para levantamento de suas historias de vida profissional e sua relação com empreedimentos inovadores, foram encontrados seis sujeitos que preenchiam os pré-requisitos e uma dezena de outros descartados. Esses seis profissionais eram provenientes de organizações distintas quanto ao porte, à complexidade, setor de atuação e número de funcionários. Em cada um dos sujeitos, havia elementos que permitiam supor a existência de um processo criativo que o levou a empreender alguma ação inovadora. Não houve dúvidas que esse grupo não poderia ser considerado representativo de alguma população, porém todos eles poderiam ser capazes de descrever o processo criativo inovador-empreendedor, que é o objeto desta tese.

\subsection{Procedimentos}


Feitos os contatos com pessoas do ambiente de negócios inovadores, foram identificados casos de indivíduos que criaram empreendimentos inovadores considerando particularmente aqueles (as) que tiveram projetos rejeitados no ambiente organizacional e imprimiram novo rumo à sua trajetória profissional para realizá-la. A partir dessas indicações, foi feito o contato telefônico com os potenciais sujeitos e, através de uma préentrevista foi feita a avaliação se os sujeitos preenchiam os requisitos estabelecidos no desenho da pesquisa, a saber, se haviam tido a experiência recente de criação de um negócio próprio consistente com a condição de empreendimento-inovador.

Nessa pré-entrevista foram apresentados os objetivos da pesquisa e a solicitação da colaboração como sujeito da presente tese. As entrevistas foram anotadas, tendo os sujeitos sido informados sobre a possibilidade de ter acesso às anotações a qualquer momento da entrevista e também ao texto completo dela em momento posterior. Houve concordância de todos (as) os (as) entrevistados (as) que, em sua maioria, manifestou desejo de receber o texto completo.

$\mathrm{Na}$ entrevista para a coleta de dados, cada sujeito foi convidado a relatar livremente o desenvolvimento de seu projeto de empreendimento inovador, contando todos os aspectos pessoais, profissionais e circunstanciais que teriam alguma relação com essa trajetória empreendedora. Sem apresentar um roteiro ao sujeito, as entrevistas foram apoiadas em roteiro (descrito a seguir) utilizado apenas pela entrevistadora para avaliação de eventuais necessidades de complementação, valorização e consistência dos dados verbalizados. Esse roteiro foi um apoio significativo para evitar digressões, que não contribuíssem para o tema central e para se ter um mesmo referencial de dados esperados em relação a todos os seis sujeitos. 


\section{ROTEIRO}

\section{Dados biográficos}

\section{$\underline{\text { Família de origem }}$}

- Contexto familiar: número de irmãos; seu lugar na família;

- Espaço físico e local de moradia (cidade / campo / interior / capital); a família nuclear, família extensa e a comunidade (relações entre elas)

- Modelos: pai, mãe, tios (as), avós

- Como define a sua família?

- Religião e prática religiosa

- Fatos significativos que marcaram sua infância e adolescência

\section{$\underline{\text { Família atual }}$}

- Contexto: número de pessoas, moradia, local, seu espaço na família atual, a família nuclear, família extensa e a comunidade (relações entre elas)

- Como define a sua família?

- Religião e prática religiosa

- Fatos significativos 


\section{Trajetória profissional}

- Fale-me de sua trajetória profissional

- Descreva, com detalhes, a mudança de rumo em sua carreira (de funcionário (a) a empreendedor (a))

- Que elementos pesaram em sua decisão?

- Quais os fundamentos da dúvida?

- Conte, em detalhes, a gênese de sua criação / invenção

\section{Projeto empreendedor}

- Descreva como desenvolveu seu projeto empreendedor

- Quais fatores, a seu ver, contribuíram para o sucesso de seu projeto?

\subsection{Análise dos dados}

As entrevistas foram submetidas à análise por categorias que, em seu conjunto, contivessem os elementos que poderiam indicar algum tipo de causalidade com o empreendimento inovador empreendedor. Tais categorias foram: dados biográficos, características criativas pessoais empreendedoras, ações que poderiam ser categorizadas como descoberta, invenção, inovação, rearranjo ou criação, obstáculos e ações para superação dos obstáculos. Tendo em mãos as narrativas e esse roteiro para analisar a textura de causalidades, a reflexão sobre tais elementos, a partir de diversas leituras de cada caso, completou as ferramentas para se entender e avaliar o empreendedorismo inovador, como manifestação da criatividade no contexto da inovação, resultando nos 
quadros 1 a 6, em que nas colunas à esquerda são colocadas as categorias e nas colunas à direita são reproduzidas as frases proferidas pelo sujeito, referidas a cada uma delas.

Para se elaborar os quadros, foram efetuadas diversas leituras de cada entrevista tendo como critério básico a consistência entre os elementos em suas relações de causalidade. Essa técnica de análise de conteúdo foi apoiada nos procedimentos de Bardin (2007). A identificação das categorias acima descritas foi realizada a partir de destaque em cores das frases que se enquadravam e forneciam informações sobre cada uma delas.

Os dados foram organizados em um quadro para cada sujeito, sendo cada quadro precedido por uma síntese dos dados biográficos e profissionais de cada sujeito. Ao final do quadro, é apresentada outra síntese na qual é sumariado o processo criativo inovadorempreendedor de cada sujeito.

À exceção de uma pessoa que declarou não dispor desse tempo para esta finalidade, todos os demais sujeitos disponibilizaram o tempo necessário para a entrevista que foi realizada no local de trabalho de cada um (a). Os sujeitos mostraram-se motivados a relatar suas experiências recentes de empreendedorismo e muitos deles estenderam, voluntariamente, o tempo dedicado à entrevista em função do interesse em expor a sua vivência.

\subsection{Resultados}

Os resultados obtidos são apresentados na forma de um quadro para cada sujeito que, a seguir, passam a ser denominados aleatoriamente pelas letras do alfabeto. Antes de cada quadro, há uma síntese dos dados biográficos e profissionais de cada sujeito e, ao final da 
descrição do caso, elaborou-se um comentário em que a ação empreendedora é interpretada a partir do referencial proposto nos capítulos anteriores.

Caso A: sexo feminino, criou e patenteou adesivo tendo a água como solvente. Em sua trajetória profissional, teve rejeitado um projeto para desenvolver esta nova linha de produtos em empresa em que trabalhava. Mesmo sem contato direto com a linha de produção, a toxicidade dos solventes utilizados nesse tipo de produtos foi causadora de uma doença diagnosticada como muito grave. Ela desenvolveu a fórmula, criou a própria empresa para fabricar e comercializar os produtos. Inicialmente contou com a incubação de sua empresa para testar e prototipar a idéia. Tendo avançado muito no desenvolvimento do negócio, passou a contar com ajuda de um sócio.

\begin{tabular}{|c|c|c|}
\hline Categoria & Caso A & \\
\hline Dados biográficos & & $\begin{array}{l}\text { Meu pai e meu avô foram empreendedores. } \\
\text { Meu pai queria ter negócio próprio, não queria seguir ao passos da sua } \\
\text { família, por isso veio para o Brasil, com cinco filhos. Encontrou um } \\
\text { mundo muito estranho. Perdeu dinheiro. Sempre foi muito ativo como } \\
\text { comerciante. Sua ambição era provar para si mesmo que não ia dar errado. } \\
\text { Meu pai veio para o Brasil, perdeu, ganhou, etc., mas sempre dizia que ia } \\
\text { dar certo lá na frente... } \\
\text { Minha mãe trabalhava junto com meu pai. Meus pais esperavam muito dos } \\
\text { filhos: "Tem que dar certo" } \\
\text { Ainda criança, eu acompanhava meu pai e o ajudava a traduzir para o } \\
\text { português; meu pai perguntava se podia assinar ou não e eu o ajudava a } \\
\text { brigar. Ajudá-lo fez com que eu ficasse mais fluente para me virar. } \\
\text { Vim com oito anos, num navio. } \\
\text { Sou divorciada. }\end{array}$ \\
\hline Características & & eu pai me perguntava: porque trabalhar para os outros? E me incentivava \\
\hline
\end{tabular}




\begin{tabular}{|c|c|}
\hline $\begin{array}{l}\text { pessoais criativas e } \\
\text { / ou } \\
\text { empreendedoras }\end{array}$ & $\begin{array}{l}\text { a ser proprietária, empresária. } \\
\text { - } \text { Sempre tive o sonho de lançar produto novo } \\
\text { - A família que veio para o Brasil não tinha ninguém. "Tem que dar certo", } \\
\text { era frase do meu pai. Arrumei emprego pelo jornal. Não havia quem } \\
\text { indicasse, laços, família [extensa]. A família [nuclear] era muito unida. } \\
\text { - Sou trabalhadora e briguenta. Não consigo entender quem não é super } \\
\text { trabalhador. Acho que venho de uma família e de uma sociedade } \\
\text { diferentes. } \\
\text { - Gosto de comer, cozinhar, mexer na Internet, viajar. Divirto-me com muita } \\
\text { - Coisa. } \\
\text { - Se eu me aposentar, quero viajar, dar aulas para criança, ser guia turística, } \\
\text { gosto de pessoas. } \\
\text { determinado produto que era vendido em grandes quantidades para algo } \\
\text { doméstico, tornando o produto vendável no varejo. } \\
\text { - }\end{array}$ \\
\hline $\begin{array}{l}\text { Descoberta, } \\
\text { invenção, criação } \\
\text { ou inovação }\end{array}$ & $\begin{array}{l}\text { - } \text { Características diferenciadas do produto } \\
\text { - Não parei neste produto. Tenho tantas idéias. Tudo começa na curiosidade. } \\
\text { - } \quad \text { TTenho] várias patentes. } \\
\text { - Proposta: desenvolvimento de produtos por meio de tecnologia limpa. }\end{array}$ \\
\hline Obstáculos & $\begin{array}{l}\text { - A empresa não quer fazer: o timing é diferente. } \\
\text { - Já tinha feito pesquisa e tinha sugerido para a empresa o desenvolvimento } \\
\text { do produto. Não teve eco. Empresa é imediatista. } \\
\text { - Vai fazer investimento de } 2 \text { a } 3 \text { anos em mim?? }\end{array}$ \\
\hline $\begin{array}{l}\text { Superação de } \\
\text { obstáculos }\end{array}$ & $\begin{array}{l}\text { - } \quad \text { Os filhos já estão grandes. Não há problema de dinheiro. } \\
\text { - } \quad \text { Encontrei o momento propício; já conhecia incubadoras e órgãos de }\end{array}$ \\
\hline
\end{tabular}




\begin{tabular}{|l|l|l|}
\hline fomento & Tive sorte na vida profissional; queria devolver algo para a sociedade. \\
$\bullet$ & Tive redução de $30 \%$ dos glóbulos brancos quando era gerente de \\
& desenvolvimento, mesmo tendo contato com o produto somente pelo ar. \\
& Fiquei afastada por três meses, depois, me curei. \\
Orgulho de ver o produto disseminado em bons lugares. Prazer em & divulgá-lo e dizer que é ecológico, de alta performance e que pode ajudar \\
$\bullet$ & Gosto de sentir que dou o melhor para a pessoa, de empregar muita gente, \\
praticar a inclusão social, fazer a diferença na vida das pessoas. & Gostaria que a empresa ganhasse mais para pagar salário maior.
\end{tabular}

A pessoa, aqui denominada caso $\mathbf{A}$, teve sua trajetória profissional bem sucedida na área de pesquisa e desenvolvimento interrompida quando da recusa de um projeto seu de inovação de produto com tecnologia limpa. A toxicidade dos produtos que eram, até então, fabricados na empresa em que ela trabalhava produziram efeitos nocivos à sua saúde e ela, então, se dedicou ao desenvolvimento do projeto rejeitado por meio da criação de uma empresa própria que contou com o apoio de uma incubadora de empresas de base tecnológica. Em sua biografia, destacam-se elementos de convívio com outra cultura (familiar) e com o empreendedorismo de seu pai.

Esse caso (caso A) confirma a importância da competição por um padrão de excelência, característico da motivação para a auto-realização (McClelland et al., 1953). A pessoa assim motivada não compete com outros (as), mas com um nível de exigência internalizado ("Tem que dar certo"). Revela-se também a causalidade pessoal, definida por De Charms (1968) como a "iniciação, por um indivíduo, de um comportamento com a intenção de produzir uma mudança no seu ambiente" (p.6) em especial na decisão da 
pessoa criar sua própria empresa depois de ter seu projeto rejeitado pela organização em que trabalhava. Descoberta, invenção e inovação, neste caso, se integram a partir do espírito empreendedor manifesto pela pessoa entrevistada. A concessão de patente e reconhecimento por meio de prêmio de empreendedorismo inovador tornam este caso o mais emblemático do ponto de vista do presente estudo.

Caso B: sexo feminino, criou e patenteou novo eletrodoméstico de linha branca. Detectou a necessidade do produto pela própria vivência e acreditou que o incômodo que sentia pela ausência de um produto como aquele poderia ser compartilhado por outras mulheres. Contou com o apoio do irmão para realizar as primeiras experiências e com a incubadora de empresas para a fase de desenvolvimento do negócio.

\begin{tabular}{|c|c|c|}
\hline Categoria & Caso B & \\
\hline Dados biográficos & & $\begin{array}{l}\text { Depois de uma experiência de } 18 \text { anos como comissária de vôo, resolvi } \\
\text { parar. "Cansei". A profissão era desumana; a segurança, precária. }\end{array}$ \\
\hline $\begin{array}{l}\text { Características } \\
\text { pessoais criativas e } \\
\text { / ou } \\
\text { empreendedoras }\end{array}$ & $\bullet$ & $\begin{array}{l}\text { "Vendi" a idéia para meu irmão e ele aceitou bem. Trabalhávamos nos } \\
\text { finais de semana e nos feriados. Levamos seis meses para equacionar os } \\
\text { problemas técnicos, como o fato de que uma roupa que já foi passada e só } \\
\text { tem pequenas marcas é diferente da roupa que acabou de ser lavada. Isso } \\
\text { se tornou um protótipo provisório, que ainda não era automatizado. } \\
\text { Mesmo tendo tido o protótipo recusado em três empresas e estando à } \\
\text { espera da patente, decidi que meu TCC na faculdade seria sobre este } \\
\text { assunto (uma das áreas da Arquitetura é o desenho industrial). Falei com } \\
\text { meu orientador que gostou da idéia e me incentivou a fazer. Criei o } \\
\text { protótipo (muitas pranchas). A banca adorou. } \\
\text { Depois, perguntei-me "O que fazer com a patente?" Considerei que tinha } \\
\text { recursos; "não iria atrás de ninguém". Mandei fazer as peças e montei o }\end{array}$ \\
\hline
\end{tabular}




\begin{tabular}{|c|c|}
\hline & $\begin{array}{l}\text { produto em sua casa, com meu irmão. } \\
\text { - Pelo jornal, vi que havia inscrições abertas para incubação de empresas, } \\
\text { para projetos inovadores numa incubadora Como o projeto já estava } \\
\text { pronto, prestei a seleção e passei. Fui classificada e entrei na modalidade } \\
\text { hotel de projetos para depois ser empresa residente. } \\
\text { Depois de incubada a empresa, desenvolvemos } 30 \text { máquinas piloto e } \\
\text { solicitamos a uma firma com nome conceituado uma pesquisa qualitativa } \\
\text { com o usuário final. Inicialmente, deixamos por } 29 \text { dias as primeiras cinco } \\
\text { máquinas em casas de usuários para teste. As pessoas adoraram e não } \\
\text { queriam devolver; todos queriam pagar para ter o produto. Depois, a } \\
\text { pesquisa foi transferida para um hotel em que os aparelhos ficavam } \\
\text { expostos. Duzentas pessoas foram convidadas para a pesquisa. Havia uma } \\
\text { entrevista prévia e elas viam as máquinas em funcionamento. } 87 \% \\
\text { declararam que comprariam. }\end{array}$ \\
\hline $\begin{array}{l}\text { Descoberta, } \\
\text { invenção, criação } \\
\text { ou inovação }\end{array}$ & $\begin{array}{l}\text { Passar roupa é uma coisa que não dá para apertar um botão e deixar a } \\
\text { máquina fazendo enquanto vai estudar ou fazer outra coisa. } \\
\text { Na aviação, leva-se na mala um uniforme extra e usava-se o vapor do } \\
\text { chuveiro para alisar a roupa. Pendura-se a roupa no cabide enquanto toma- } \\
\text { se banho, pois, nos hotéis, o aquecimento é feito por caldeiras e dá para } \\
\text { secar mesmo com a umidade. Lembrei-me daquilo, mas vi que, em casa, } \\
\text { não há tanto vapor e o chuveiro elétrico é caro. Como estava estudando } \\
\text { Arquitetura, resolvi pesquisar aquilo e fazer um modelo. Meu irmão, } \\
\text { técnico em mecânica, me ajudou a instalar o modelo em casa. }\end{array}$ \\
\hline Obstáculos & $\begin{array}{l}\text { O produto funcionava; já fazia um ano que eu estava usando. Tentei, } \\
\text { então, vender para empresas. Foram três empresas de grande porte e, nas } \\
\text { três, em reuniões com gerentes, diretores, etc., eu e meu irmão fomos tidos } \\
\text { como loucos. As respostas que ouvimos foram semelhantes: "A patente } \\
\text { não vai sair; isso não é possível; demoraria três a quatro anos para } \\
\text { desenvolver; o investimento seria muito grande". Ouvimos também frases } \\
\text { como "Se fosse possível, já teriam inventado" e "Com tanto engenheiro }\end{array}$ \\
\hline
\end{tabular}




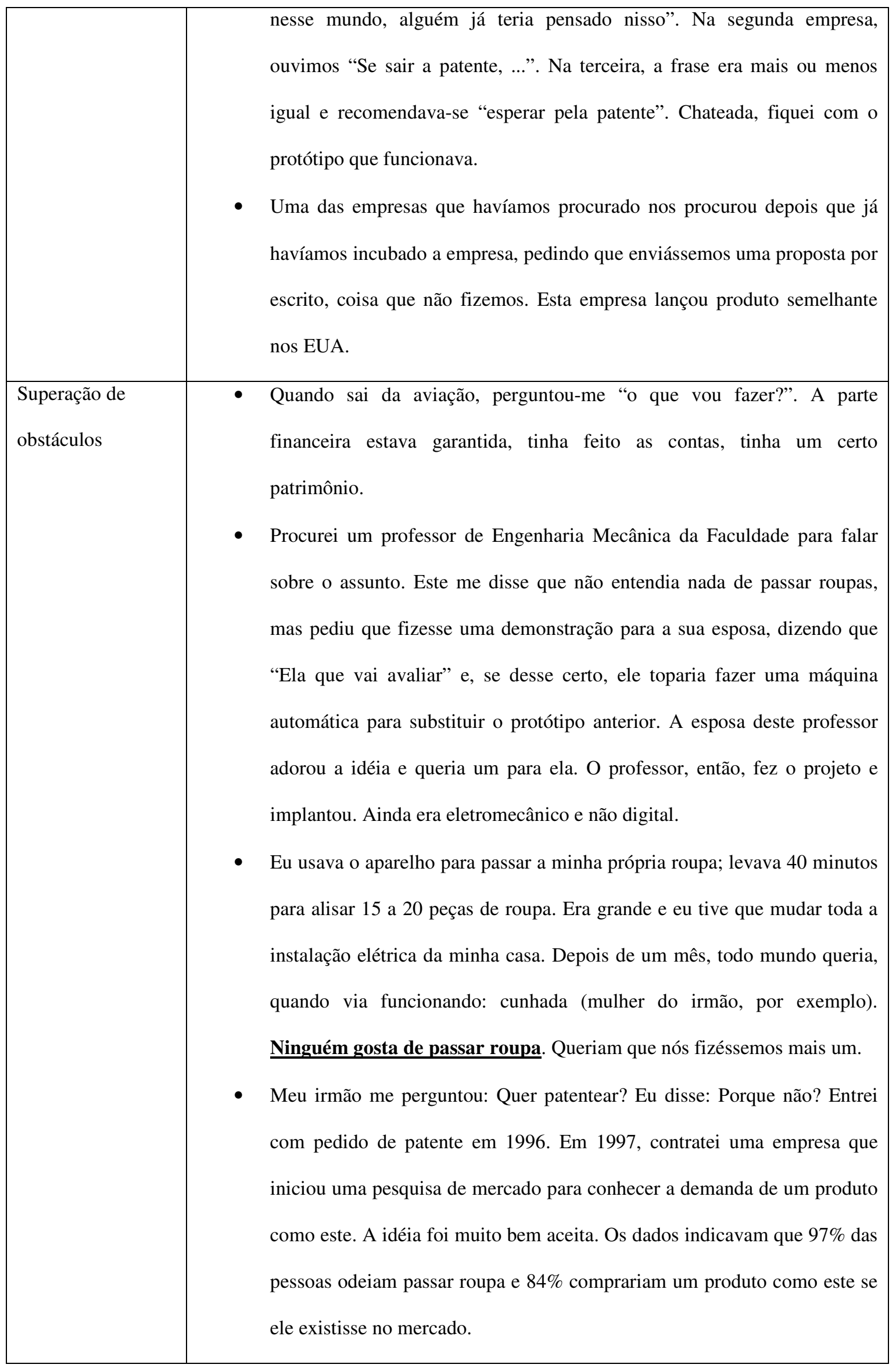


No caso B, a idéia de criar um novo eletrodoméstico surgiu da experiência prévia adquirida no cotidiano de muitas viagens como comissária de bordo. Muitos anos se passaram entre a vivência nesta profissão e a ação empreendedora que deu origem ao negócio atual, revelando que uma idéia pode permanecer incubada por longo período no plano inconsciente e ser acessada pelo consciente quando a pessoa está diante de uma oportunidade relacionada àquela idéia.

O caso B apresenta duas peculiaridades não comuns aos outros em que se sobressaem aspectos discutidos na literatura: a primeira diz respeito ao medo que a pessoa manifesta de "ter sua idéia roubada", confirmando um dos traços de personalidade identificados no estudo de Zibarras et al. (2008), a saber, o "medo de ser criticado ou culpado". O segundo aspecto diz respeito à origem da idéia que levou à criação do produto. A pessoa (caso B) se inspirou em sua própria aversão a determinado tipo de atividade, pesquisou se outras pessoas nutriam o mesmo sentimento que ela sobre isso e desenvolveu uma solução que liberasse a ela e a outras pessoas dessa atividade. Na tipologia proposta por Unsworth (2001), trata-se da criatividade contributiva, em que há uma "resposta voluntária a questões abertas específicas, na qual os problemas são apresentados (colocados) em função de motivos internos".

Descoberta, invenção e inovação, da mesma forma que no caso A, se integram a partir da ação empreendedora manifesta pela pessoa entrevistada.

Caso C: sexo masculino, criou empresa na área de telefonia. Em função de uma vivência pessoal no contato com familiares que estavam em outras cidades, percebeu a necessidade de comparação de preços entre operadoras que prestam esse tipo de serviço e "inventou" 
um sistema que possibilita a comparação de preços, subsidiando a tomada de decisão sobre as vantagens de uma dada operadora em um determinado momento.

\begin{tabular}{|c|c|c|}
\hline Categoria & Caso C & \\
\hline Dados biográficos & & $\begin{array}{l}\text { Morávamos em um sítio na periferia da capital de São Paulo, era como se } \\
\text { fosse interior, atividades da família eram rurais, mas não como fonte de } \\
\text { renda. A família nuclear eram meus pais e minha irmã, pois o irmão mais } \\
\text { velho estudava em colégio interno e depois, foi morar com um tio no Rio } \\
\text { de Janeiro. A família extensa quase não existia, pois os parentes de meu } \\
\text { pai moravam no Rio de Janeiro e os de minha mãe em Goiás ou em Minas } \\
\text { (Triângulo), ela era percebida quando de alguma visita de um parente, mas } \\
\text { era muito raro. A comunidade era formada por algumas famílias de } \\
\text { pessoas do comércio local ou vizinhos, na maioria, pessoas simples com } \\
\text { pouca educação formal. } \\
\text { Fatos marcantes: a separação da minha primeira esposa, a prática de dez } \\
\text { anos de terapia, que me levou a mudar muito como pessoa, a busca } \\
\text { contínua pelo aperfeiçoamento espiritual e como ser humano. }\end{array}$ \\
\hline $\begin{array}{l}\text { Características } \\
\text { pessoais criativas e } \\
\text { / ou } \\
\text { empreendedoras }\end{array}$ & $\begin{array}{l}\bullet \\
\bullet\end{array}$ & $\begin{array}{l}\text { Muita leitura, desde pequeno, aos } 12 \text { anos já havia lido tudo que havia na } \\
\text { biblioteca de casa (mais de } 100 \text { livros), incluindo a bíblia sagrada. Leitura } \\
\text { de livros sobre ocultismo que me abriram a pluraridade das religiões. } \\
\text { Militância no movimento estudantil secundarista. } \\
\text { Formei-me em engenharia e comecei a trabalhar em uma empresa nacional } \\
\text { como engenheiro de desenvolvimento de produtos; esta empresa cresceu } \\
\text { muito e tornou-se a maior empresa nacional do ramo eletrônico, e fui } \\
\text { galgando postos até me tornar gerente de desenvolvimento, quando a } \\
\text { empresa começou a declinar me desentendi com a diretoria e fui demitido. } \\
\text { Mudei para outra empresa nacional em fase de expansão, na qual fiquei } \\
\text { um ano, pois não gostei da cultura da empresa. Mudei para uma empresa }\end{array}$ \\
\hline
\end{tabular}




\begin{tabular}{|c|c|c|}
\hline & & $\begin{array}{l}\text { estrangeira de automação industrial, da qual gostei muito do trabalho e do } \\
\text { ambiente, mas ao final me desentendi com o gerente geral quanto aos } \\
\text { rumos da empresa e fui demitido, fiquei um ano desempregado e então fui } \\
\text { contratado por outra empresa nacional da qual gostava muito da cultura, } \\
\text { mas detestava o trabalho e fui demitido quando a empresa reduziu o } \\
\text { quadro a } 1 / 3 \text { em função da privatização das telecomunicações. } \\
\text { Persistência: Inicialmente inscrevi uma patente para resguardar a } \\
\text { tecnologia concebida e, entre aprender sobre patentes e conceber } \\
\text { minimamente o sistema, levei nove meses. Após dar entrada no processo } \\
\text { de patente, com a segurança de poder revelar a idéia, passei a procurar } \\
\text { quem pudesse investir no desenvolvimento do produto e criação do } \\
\text { negócio, as pessoas achavam interessante, mas não punham dinheiro, então } \\
\text { comecei a procurar entidades oficiais, BNDES, Finep. Fiquei sabendo da } \\
\text { incubadora, me inscrevi fui aprovado e lá consegui recursos para tocar o } \\
\text { projeto. }\end{array}$ \\
\hline $\begin{array}{l}\text { Descoberta, } \\
\text { invenção, criação } \\
\text { ou inovação }\end{array}$ & $\bullet$ & $\begin{array}{l}\text { Estava envolvido no desenvolvimento de outro negócio, mas como meus } \\
\text { filhos moravam no interior e eu tinha que selecionar a operadora para ligar } \\
\text { para eles, pesquisei as tarifas delas e verifiquei que era muito complexo até } \\
\text { para alguém da área saber escolher. Criei então um processo de análise de } \\
\text { tarifas e criação de tabelas para informação da operadora mais barata para } \\
\text { cada destino da ligação em cada dia da semana em cada horário do dia. } \\
\text { Estas tabelas precisavam de atualização frequente. Percebi que aí poderia } \\
\text { haver um negócio de prestação de serviços. }\end{array}$ \\
\hline Obstáculos & $\bullet$ & $\begin{array}{l}\text { A certeza da dificuldade de achar um novo emprego na minha idade, a } \\
\text { consciência de não ser capaz mais trabalhar em algo que não me motivasse } \\
\text { e no qual não acreditasse, de não ser capaz de seguir ordens que eu não } \\
\text { concordasse, e a necessidade de criar algo que pudesse me fornecer a } \\
\text { subsistência e ser um legado para os meus filhos. }\end{array}$ \\
\hline
\end{tabular}




\begin{tabular}{|l|l|}
\hline & $\begin{array}{l}\text { A dúvida naquele momento era se ainda seria possível encontrar um } \\
\text { ambiente de trabalho não dirigido por mim, no qual eu conseguisse me } \\
\text { realizar profissionalmente, que fosse ético, justo e voltado para o } \\
\text { desenvolvimento contínuo. Não era uma dúvida, era uma certeza, não } \\
\text { existia. }\end{array}$ \\
\hline Superação de & \\
\hline obstáculos & \\
\hline
\end{tabular}

A pessoa denominada caso $\mathbf{C}$ teve a idéia de desenvolver um sistema de telefonia a partir de problemas enfrentados em seu cotidiano. Vale notar que, embora grande número de pessoas enfrente este mesmo problema em seu dia-a-dia, não são todos que desenvolvem ações empreendedoras e inovadoras para resolvê-lo, revelando assim que uma das características das pessoas criativas é a existência dinamismos psíquicos que acionam impulsos criativos.

O fato de que, no caso $\mathbf{C}$, a base para a criação do sistema inovador ligado à telefonia originou-se na busca de solução para problemas que a pessoa enfrentava em seu cotidiano, caracteriza a criatividade contributiva, na visão de Unsworth (2001). O objeto da criação o desenvolvimento do sistema que permite a precificação, a qualquer momento, da chamada telefônica das operadoras que prestam o mesmo tipo de serviço - dependeu da criatividade para a combinação de elementos. Os dados - armazenados em bancos de dados - são combinados ao instante de forma a produzir a resposta à questão do melhor preço. O elemento criativo está no arranjo peculiar dos dados que, combinados, oferecem a solução ao problema. 
O caso $\mathbf{C}$ configura uma invenção (identificação e combinação de propriedades da matéria) que, aliada à atitude empreendedora do sujeito, pôde se transformar em inovação. A criatividade manifesta neste caso ocorreu a partir de elementos cujas propriedades eram conhecidas que, uma vez combinados, permitiram a produção do novo.

Caso D: sexo masculino, desenvolveu cosméticos à base de nanoemulsões. Tendo trabalhado com nanotecnologias em outro tipo de atividade, combinou essa competência técnica com a experiência de ter ajudado, anos antes, a irmã com seu negócio na área de cosméticos. Ainda em fase de desenvolvimento dos produtos, a empresa encontra-se incubada.

\begin{tabular}{|c|c|}
\hline Categoria & Caso D \\
\hline Dados biográficos & $\begin{array}{l}\text { - Eu tinha uma formação muito valorizada pelo mercado: experiência em } \\
\text { P\&D + visão de negócio. } \\
\text { - Meu pai, um fiscal do ICMS, foi importante na primeira fase da minha } \\
\text { vida e, depois, para empreender: ajudou-me com dinheiro e no } \\
\text { conhecimento das relações das empresas com órgãos públicos (nota fiscal, } \\
\text { etc.); conhecimentos administrativos e contábeis. } \\
\text { Minha mãe, dona de casa. Meu avô, de parte de mãe, português; } \\
\text { antecedentes (mais longínquos) do pai, holandeses e ingleses. }\end{array}$ \\
\hline $\begin{array}{l}\text { Características } \\
\text { pessoais criativas e } \\
\text { / ou } \\
\text { empreendedoras }\end{array}$ & $\begin{array}{l}\text { - Tinha duas carreiras paralelas: como engenheiro de qualidade e como } \\
\text { empresário junto com a irmã. } \\
\text { - Não tinha vontade de ser empresário nem de ir para a área acadêmica. } \\
\text { Queria mesmo P\&D. } \\
\text { - Trabalhei, nesta empresa, com o desenvolvimento de polímeros (plásticos } \\
\text { e borrachas) tanto em processos quanto em produtos. } \\
\text { A outra vertente, paralela, da carreira, foi puxada pela minha irmã, }\end{array}$ \\
\hline
\end{tabular}




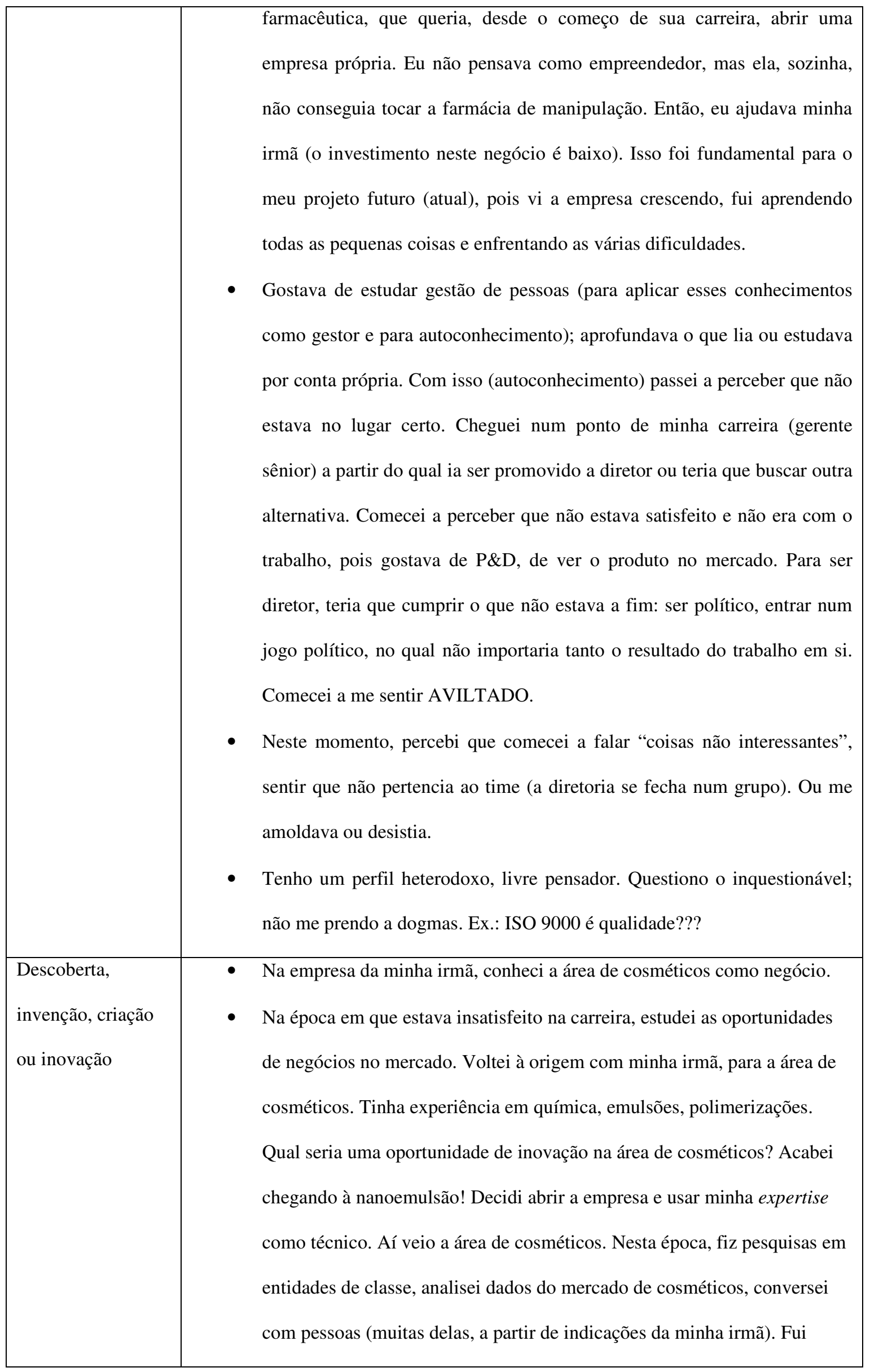




\begin{tabular}{|l|l|}
\hline \multirow{1}{*}{} & estruturando. Depois da idéia do projeto, precisava de dados específicos \\
& daquele nicho. \\
& Percebi que o que há de mais novo e as tendências da área de cosméticos \\
& eram para tratamento (cosmecêuticos). Criam-se ativos específicos. Tive \\
& um insight: veio a idéia do nano. Já tinha trabalhado com nanoemulsões no \\
& início da carreira. Na hora da idéia, tive um frisson! Comecei a modelar a \\
& idéia. \\
\hline Obstáculos & Minha esposa é médica, deu força, entrou de sócia. Ela trabalha com \\
\hline Superação de & seguradoras de saúde. Tinha a reserva financeira e o dinheiro do trabalho \\
obstáculos & da minha esposa.
\end{tabular}

A pessoa denominada caso D desenvolve uma carreira profissional bem sucedida e, simultaneamente, ajuda sua irmã que tem um negócio próprio. Em determinado momento, a proposta de mudança de cargo na empresa em que trabalhava desafia seus valores e crenças, incitando-o a se desligar e motivando-o a iniciar seu próprio negócio.

Esse caso (caso D) ilustra, dentre outros, o fenômeno do insight. No momento em que decide abrir o próprio negócio, o sujeito se pergunta por que não combinar a experiência profissional que teve na área de nanoemulsões com o ramo de cosméticos que conhecia por meio do negócio de sua irmã. Esse movimento integra suas duas "carreiras", a técnica e a empreendedora. Trata-se de uma invenção que embasa a gênese do empreendimento inovador.

Sua descrição autobiográfica (“Tenho um perfil heterodoxo”, "Não me prendo a dogmas”) confirma a pesquisa de Zibarras et al. (2008) sobre a personalidade criativa. 
Caso E: sexo feminino, proprietária de empresa na área de assessoria de imprensa. Pioneira na prestação desse serviço no Brasil, que não contava com este tipo de negócio, adaptou para a realidade local idéias provenientes de outros países com que teve contato por meio da agência em que trabalhava. Associou-se a uma colega de trabalho para abrir sua empresa. Em função de sua trajetória empreendedora, assessora negócios nascentes em incubadoras.

\begin{tabular}{|c|c|c|}
\hline Categoria & Caso E & \\
\hline Dados biográficos & $\bullet$ & $\begin{array}{l}\text { Há dez anos atrás, tive a síndrome do pânico (após um aborto). Fiz terapia } \\
\text { em paralelo com a carreira. A minha terapeuta, de linha psicodramatista, } \\
\text { me incentivava para o empreendedorismo. } \\
\text { Meu pai, descendente de italianos; minha mãe, de portugueses. Meus avós } \\
\text { imigraram para o Brasil. A minha mãe era costureira e tinha um ateliê em } \\
\text { casa; quando precisava entregar vários vestidos para um casamento, ficava } \\
\text { até muito tarde da noite trabalhando. Meu pai trabalhava numa empresa de } \\
\text { tecelagem (empresas grandes, tipo Rhodia). } \\
\text { Eu era a única filha mulher, dois irmãos, } 10 \text { anos mais velhos. Quando } \\
\text { tinha } 18 \text { anos, lia cinco livros ao mesmo tempo, estudava inglês, russo } \\
\text { (tempos de marxista). Gostava de estudar, ler, tecnologia. Fiz } \\
\text { processamento de dados na época do colégio, mas logo percebi que } \\
\text { gostava como usuária, não como programadora. Fiquei frustrada, mas fui } \\
\text { que com matemática. }\end{array}$ \\
\hline $\begin{array}{l}\text { Características } \\
\text { pessoais criativas e } \\
\text { / ou } \\
\text { empreendedoras }\end{array}$ & & $\begin{array}{l}\text { Comecei a desacreditar de franchising, achando que empreender não é } \\
\text { isto. Meu marido tinha loja de tecnologia no esquema de franchising. Eu } \\
\text { segui rumo paralelo ao dele. O franchising dá uma coisa pronta ao } \\
\text { empreendedor; a pessoa não é aquilo. O empreendedor é aquele que sabe } \\
\text { fazer algo muito bem ("tá no sangue") e quer fazer do jeito dele. É mais }\end{array}$ \\
\hline
\end{tabular}




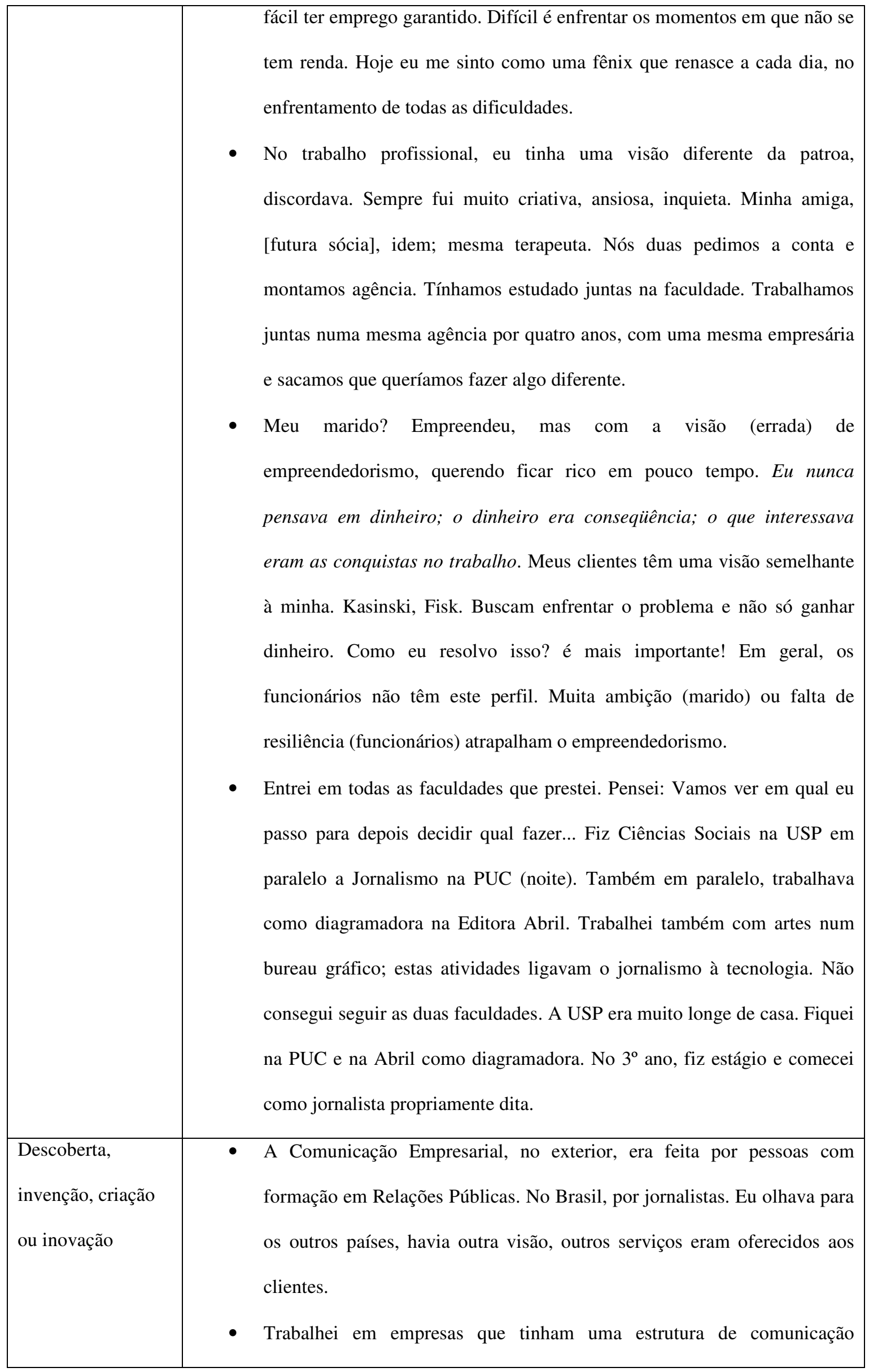




\begin{tabular}{|c|c|}
\hline & $\begin{array}{l}\text { vinculada a grupos americanos; absorvi a visão de lá. Tropicalizei. Aqui já } \\
\text { havia empresas fazendo isso, mas para grandes grupos. Foi um nicho de } \\
\text { mercado trazer este trabalho de relações públicas para as empresas médias. } \\
\text { Na época em que cursei jornalismo, nem havia uma matéria como } \\
\text { "Assessoria de Imprensa", "Jornalismo Empresarial” ou assemelhadas. } \\
\text { Não havia Internet. Fiz cursos em Associações. Vi tendências. Participei } \\
\text { de Congressos na Área de Comunicação. A dona da agência não tinha esta } \\
\text { preocupação. }\end{array}$ \\
\hline Obstáculos & $\begin{array}{l}\text { - Descrédito por parte de outros jornalistas. } \\
\text { - } \text { Recusa da proprietária da agência em que trabalhava a respeito deste novo } \\
\text { negócio. } \\
\text { - No começo, muita dificuldade, um cliente só, não cobria o salário de nós } \\
\text { duas }\end{array}$ \\
\hline $\begin{array}{l}\text { Superação de } \\
\text { obstáculos }\end{array}$ & $\begin{array}{l}\text { - Dúvida? Impulso! Eu acreditava que ia dar certo; jornalistas elogiavam o } \\
\text { meu trabalho. O relacionamento com a dona da agência estava ficando } \\
\text { difícil, discordava dela. CRISE + OTIMISMO + RESILIÊNCIA. O que } \\
\text { iam perder? Fui construindo o negócio de forma sustentada, investindo } \\
\text { com o que ganhava. }\end{array}$ \\
\hline
\end{tabular}

Ao longo de sua trajetória de carreira em organizações, a pessoa denominada caso $\mathbf{E}$ mantinha um olhar inovador, atento àquilo que se fazia em empresas estrangeiras, por exemplo, e uma atitude inconformista com relação à falta de visão de futuro que via em seu ambiente de trabalho. Contando com o apoio de uma amiga que compartilhava o mesmo sentimento, decidiu iniciar seu próprio negócio, visando desenvolver essa visão inovadora mais plenamente.

O processo criativo do caso E envolveu a "tropicalização" de uma forma de trabalho já praticada em outros países. Não se trata de descoberta ou de invenção, mas é uma 
inovação, sustentada na adaptação de certas práticas a uma realidade diferente. Não se trata de plágio, mas de criação, da mesma forma que as fantasias e variações produzidas por Louis Moreau Gottschalk sobre os hinos nacionais de vários países ou as Bachiannas Brasileiras, de Villa Lobos. Cria-se sobre algo que já existe, mas introduz-se a marca pessoal da criação. Quanto à pessoa criativa, o caso, como os demais, ilustra a força da causalidade pessoal (De Charms, 1968).

Caso F: sexo masculino, proprietário de empresa de publicidade. Quando trabalhava em grandes agências, criou propagandas amplamente veiculadas na mídia. Descreve o processo criativo como funcionário destas organizações e, posteriormente, com a criação de seu próprio negócio.

\begin{tabular}{|c|c|c|}
\hline Categoria & Caso $\mathbf{F}$ & \\
\hline Dados biográficos & & $\begin{array}{l}\text { Família de imigrantes que vieram para o Brasil "sem um tostão no bolso". } \\
\text { O avô começou como mascate vendendo gravatas que lhe eram dadas pelo } \\
\text { irmão que havia chegado há mais tempo no Brasil, mesmo sem saber falar } \\
\text { a língua [portuguesa]. Todos [membros da família que imigrou] } \\
\text { sobreviveram do comércio. }\end{array}$ \\
\hline $\begin{array}{l}\text { Características } \\
\text { pessoais criativas e } \\
\text { / ou } \\
\text { empreendedoras }\end{array}$ & & $\begin{array}{l}\text { "Saber ouvir sem julgar" para poder entender o que o cliente quer e o que } \\
\text { precisa. }\end{array}$ \\
\hline $\begin{array}{l}\text { Descoberta, } \\
\text { invenção, criação } \\
\text { ou inovação }\end{array}$ & & Criou várias propagandas que se tornaram bastante conhecidas do público. \\
\hline Obstáculos & & $\begin{array}{l}\text { O momento mais legal é quando a idéia é "parida". Depois, vem o diretor } \\
\text { de criação, o pessoal do atendimento, o produto pronto; isso tudo não é tão }\end{array}$ \\
\hline
\end{tabular}




\begin{tabular}{|l|ll|}
\hline & & legal. Nem ver a propaganda na TV. \\
& $\bullet \quad$ Criar e atender ao cliente. \\
\hline Superação de & $\bullet \quad$ Criação de empresa própria. Poder ter o domínio do processo completo, \\
obstáculos & ser dono do negócio. \\
\hline
\end{tabular}

Em sua carreira na área de publicidade, a pessoa denominada caso $\mathbf{F}$ criou propagandas e campanhas de grande alcance na mídia. Trabalhando para grandes empresas, ele não encontrava sua plena realização profissional, revelando que, mesmo nas chamadas indústrias criativas, não há necessariamente espaço para a manifestação da criatividade individual.

No caso F, fica patente a distinção entre o momento da criação e sua posterior apropriação por outrem, gerando estranhamento no sujeito da criação. O caso ilustra também a tensão "criação - mercado" e a tendência a inviabilizar o novo, mesmo nas chamadas indústrias criativas.

Do ponto de vista biográfico, destaca-se, como no caso $\mathbf{A}$, a convivência com outra cultura (família de estrangeiros) como fator potencializador da criatividade.

\subsection{Visão geral dos resultados}

O exame dos casos mostra elementos comuns aos sujeitos e revela claramente o processo criativo-empreendedor e alguns de elementos constituintes e / ou correlatos, a saber, a criatividade, as descobertas, as invenções, as inovações e o empreendedorismo, fato que por si mesmo estimula estudos futuros mais amplos, explorando aspectos revelados em casos específicos e não em outros. 
Considerando as tipologias descritas por Unsworth (2001) no capítulo II, os comportamentos empreendedores manifestos nos casos A, B, C e D tiveram início via escolha auto-determinada, não foram respostas a demandas externas. "Na escolha autodeterminada, revela-se a autonomia e as pessoas experienciam a si próprias como iniciadoras de seu comportamento". O caso A, inicialmente, pode ser analisado como de criatividade esperada, na linguagem desse autor, pois havia "a necessidade de descobrir problemas em função de motivos exteriores". Depois, passa à contributiva, pois a pessoa "escolhe se engajar na solução criativa de um problema no qual ele (a) não está diretamente envolvida". Os casos B, C e D seriam de criatividade proativa, segundo a visão de Unsworth (2001), pois houve a "busca ativa por problemas para resolver ou o processo de descobrir problemas em função de motivos internos". Nos casos E, e F, as ações foram causadas por demandas externas, ou seja, os indivíduos se engajaram nesse tipo de comportamento porque a situação assim o exigiu. $\mathbf{O}$ caso $\mathbf{F}$ revela diversas facetas da criatividade no universo dos negócios. Inserido numa indústria criativa como a da publicidade, sua trajetória corrobora a análise de Tschang (2007) de que "a evolução de qualquer organização leva cada vez mais a considerações sobre eficácia e, simultaneamente, à redução das preocupações com a inovação, à custa da criatividade" (p. 989), fator que o afasta da grande organização e o leva à criação de seu próprio negócio. O caso ilustra também que a criatividade encontra mais espaço para expressão nas indústrias nascentes, mesmo na chamada indústria criativa.

A convivência dos sujeitos A e F com outras culturas emergiu como um elemento potencializador tanto da sua criatividade quanto de seu empreendedorismo, indicando que o contato precoce com o "outro", o "diferente" pode contribuir para a inovação. A teoria 
da Gestalt, com seu princípio figura - fundo, ajuda a explicar este processo. Nos casos mencionados, identidade e alteridade se alternavam, ora como figura, ora como fundo, configurando a flexibilidade psicológica necessária para isso. A entrevista com caso A indicou que, desde criança, ela acompanhava seu pai em visitas comerciais e o auxiliava como tradutora e intérprete, da língua portuguesa para sua língua de origem e vice-versa. A atitude empreendedora se beneficiou sobremaneira pelo convívio com os negócios do pai e com o seu papel de tradutora.

Esse fenômeno talvez possa ser explicado pela afirmação de que as "pessoas estão normalmente tão mergulhadas na própria cultura que não a vêem" (Lubart, 2008) e alerta para a importância da cultura, das influências familiares e da educação para a criatividade humana.

Vale ressaltar ainda que a globalização da economia e a internacionalização das empresas atualmente em curso possibilitam o contato intercultural que podem vir a beneficiar, sobremaneira, a criatividade e a inovação.

\subsection{Criatividade e criação de empresas: para além do empreendedorismo}

Mesmo que a descoberta e a invenção não estejam sempre presentes, a criatividade está subjacente a todos os casos de inovação estudados. Esse fato leva à reflexão sobre os motivos que estimulam as pessoas a criar. Como mencionado no caso $\mathbf{C}$, inúmeras pessoas que enfrentam o mesmo problema cotidiano não se motivaram a criar um sistema que as ajudasse a resolvê-lo. Assim, é possível afirmar que as pessoas criativas são diferenciadas.

No cenário atual das organizações, descrito no capítulo $\mathrm{V}$, as empresas necessitam inovação e, desse ponto de vista, pessoas criativas são estratégicas. Entretanto, mesmo 
neste contexto, é possível identificar muitos casos de pessoas que optaram pela criação de uma nova empresa pelo fato de ter seus projetos, ideais ou criações rejeitadas nas empresas em que anteriormente trabalhavam.

Compreender porque as organizações deixam passar oportunidades de inovação demandaria novos estudos. Pode-se perguntar se isso se deve à cegueira dos agentes de reconhecimento, mas é igualmente possível questionar a relação deste fenômeno com processos seletivos, avaliação do desempenho ou gestão do conhecimento. 


\section{Capítulo VII}




\section{Conclusões}

Este capítulo apresenta as principais conclusões do presente estudo, tanto do ponto de vista dos elementos conceituais como com relação às investigações empíricas procedidas. Recomendações para futuros estudos, bem como sugestões contributivas para pesquisas e práticas no campo da criatividade são aqui apresentadas. 
O final do século XX é um marco histórico para o sistema capitalista, período em que o lema "inovar ou morrer" ganhou dimensões concretas para a sobrevivência das organizações, das instituições - públicas e privadas - e dos indivíduos trabalhadores. Momento de incertezas, é um terreno fértil para a criatividade em todas as esferas da vida humana, uma vez que os referenciais teóricos, as referências práticas e os paradigmas de todas as ordens não mais servem de bússola norteadora para a ação humana. É também um momento em que não basta mais produzir em série ou possuir a propriedade de um meio de produção; demanda diferenciação, criação da alteridade, num cenário em que grandes e pequenos negócios podem ser expulsos a qualquer momento de um mercado cada vez mais competitivo. O mesmo se aplica aos (às) profissionais que devem se atualizar, reciclar, renovar e inovar permanentemente para sobreviver neste universo.

$\mathrm{Na}$ era das diferenças e dos diferenciais competitivos, dos valores simbólicos e de profundas transformações na vida social e econômica, o reconhecimento do novo e da originalidade são fatores cruciais para a sobrevivência e para a expressão plena de um diferencial.

No entanto, considerando que a inovação não é uma opção, mas um imperativo da competitividade no contexto organizacional e que a literatura é unânime em apontar a pressão que as organizações enfrentam para inovar - envolvendo aí um diferencial competitivo que dependerá da criatividade - este estudo indicou que, paradoxalmente, elas [empresas / organizações] nem sempre apóiam a viabilização das idéias e atos criativos de seus (suas) colaboradores (as). O ranço dos modelos tradicionais de gestão emperra os processos de inovação e impõe restrições à criatividade nesse contexto. Todos os sujeitos entrevistados tentaram agir como empreendedores internos às organizações e a maioria 
deles teve seus projetos ou idéias inovadoras recusadas, apontando para o fato de que a cultura organizacional é uma questão crucial para inovação e esta pode se configurar como obstáculo ao longo desse processo. Pelo menos em um dos casos estudados, o efeito Einstellung ou armadilha do sucesso revelou-se determinante para a interrupção de uma inovação tecnológica importante, em que os valores sustentabilidade e tecnologia limpa estavam subjacentes.

Muitos anos de convivência com um modelo de gestão que zela pela conformidade aos padrões, a repetição rotineira das práticas e a exclusão do conflito humano e da dimensão estética, fazem com que a flexibilidade do olhar para o reconhecimento do novo ainda seja uma exceção e não a regra. A inovação e a criatividade devem enfrentar, então, a rigidez e a cristalização desse modelo para poderem florescer nas organizações e na vida social em geral.

Criatividade não é imitação, plágio, rotina, cópia ou repetição. A originalidade é o parâmetro distintivo entre o que é criativo daquilo que não é, mesmo que se reconheça a existência de um continuum entre eles. Uma vez que não há originalidade em si mesma, esta será sempre julgada ou avaliada em função da cultura ou comunidade em que a criação estiver inserida, enquadrando-se em um sistema de valores e estando sujeita a toda conjuntura social, com seus estereótipos, preconceitos e vieses cognitivos. Esta é a condição que levou à escolha desse tipo de caso como objeto de estudo desta tese. Considerando o entendimento de Piaget (1985), "para interpretar a gênese dos possíveis, é preciso assinalar o papel das limitações das quais o sujeito deve libertar-se, que se prendem a uma indiferenciação inicial entre o real, o possível e o necessário" (p. 10), as pessoas entrevistadas são criativas, pois superaram os pseudo-necessários que se 
apresentaram como reais, visualizando os possíveis, seja com relação ao objeto de suas criações, seja quanto à natureza de suas experiências profissionais anteriores à criação de seus negócios.

O capitalismo metafísico (Lash, 2007) traz consigo inúmeras questões antes restritas ao universo artístico e as organizações não parecem preparadas para o seu reconhecimento. Essa ambiência gera conseqüências na carreira dos indivíduos. Para alcançar a autorealização no trabalho, pessoas como as entrevistadas neste estudo rejeitam a dependência das estruturas e metas das organizações e buscam a autenticidade e a emancipação pela criação de uma empresa.

Confirmando a tradição teórica desse campo de conhecimento, é possível afirmar que a criatividade nos negócios, objeto de estudo desta tese, não difere essencialmente da criatividade cotidiana, científica ou artística. Como se viu no capítulo II, analisando a natureza ontológica do conceito - transcendência ou objetivação - e a categoria de prática - combinação de elementos, a criatividade pode se manifestar por meio de qualquer desses referenciais e ganhar expressão em qualquer contexto humano.

No ambiente empresarial, dentre as muitas manifestações criativas, a criação de uma empresa - ação empreendedora - tem o sentido de transcendência, de instituição da alteridade (Bartoli, 2008). Seu conteúdo - o produto ou serviço proposto no negócio pode ser analisado a partir de mais de uma abordagem. Alguns podem ser vistos como objetivação (casos D e E); outros são analisados como transcendência (casos A e B). e, outros ainda, não se enquadram nessa categoria, pois configuram combinação de elementos (caso C). 
Na tipologia de Unsworth (2001), importa não somente o resultado do processo criativo para a análise do ato criativo, mas o tipo de engajamento do indivíduo com relação a ele. Os sujeitos estudados não criaram a própria empresa porque a situação assim o exigiu ou se apresentou, mas experimentaram a si próprios como causa desta ação criativa, motivados por razões internas. Revelam-se, portanto, pessoas diferenciadas, como se mencionou no capítulo III, pois esse tipo de empreendedorismo difere substancialmente da decisão de abrir um negócio próprio em função de "receber o dinheiro do fundo de garantia”. Pessoas diferenciadas como os sujeitos deste estudo tendem a desenvolver, quando inseridas em organizações, a criatividade contributiva, escolhendo, voluntariamente, se engajar na solução criativa de problemas em que não estão diretamente envolvidas ou ainda a criatividade proativa, na qual buscam os problemas a resolver motivadas por razões interiores. O cenário atual demanda profissionais assim diferenciados, mas, como se viu, nem sempre os apóia ou contribui para a viabilização de suas idéias, em muitos casos em função da cegueira do curto prazo.

O objeto da criatividade "é o transformável de todo objeto, [...], quando se aplica a ela um trabalho de modificações reestruturantes" (Fiorini, p. 195). Decorre desta mobilidade potencial do objeto - plasticidade de relações, formas e conteúdos - a associação da criatividade com a saúde mental ${ }^{48}$, uma vez que o sujeito que exerce as funções que configuram as capacidades transformadores é aquele que emerge transformado da experiência criativa.

\footnotetext{
${ }^{48}$ Lembrando que, para a psicanálise, a fixação e a tendência à repetição seriam as características das diversas patologias.
} 
Segurança e liberdade psicológicas são dois dos atributos do clima favorecedor para o ato criativo (Rogers, 1959), pois o desenvolvimento da criatividade implica o exercício da liberdade e do "correr riscos", além da disponibilização de tempo e espaço para a iniciativa pessoal. Assim, sugere-se que estudos futuros se dediquem à investigação de organizações que propiciam a seus (suas) colaboradores (as) espaço e tempo para criar e apoio a idéias e projetos de risco, bem como aprofundar a análise de outros casos de pessoas que se tornaram empreendedoras, interrompendo carreiras profissionais para criar empresas próprias a partir de motivos distintos dos tratados nesta tese.

Concluir este estudo é gratificante pela percepção de que a questão inicialmente proposta continua em aberto. No percurso de elaboração desta tese, aprendeu-se que, mais do que resolver problemas, uma pesquisa serve para levantar problemas e investir criatividade em sua compreensão. 


\section{Referências}

AKTOUF, Omar. A administração entre a tradição e a renovação. São Paulo: Atlas, 1996.

ALENCAR, Eunice M. L. Soriano. Criatividade. Brasília, DF: Ed. Universidade de Brasília, 1993.

AMABILE, Teresa. Creativity in context: Update to social psychology of creativity. Colorado, US: Westview Press, 1996. 317 p.

AMABILE, Teresa. How to kill creativity. Harvard Business Review, v. 76, n. 5, p. 7687, Sept./Oct., 1998.

ARCHER, Margaret S. Being human: The problem of agency. Cambridge, UK: University Press, 2000.

AUGRAS, Monique. Criatividade e heurística. Arquivos Brasileiros de Psicologia Aplicada, v. 24, n. 4, p. 15-29, out./dez. 1972.

BARATA, Germana. Conceito do que é tóxico muda através dos tempos. Ciência e Cultura, v. 59, n. $\quad 1, \quad$ p. 16-17. Disponível em: <http://cienciaecultura.bvs.br/pdf/cic/v59n1/a09v59n1.pdf>. Acesso em: 16 mar. 2009.

BARDIN, Laurence. Análise de conteúdo. Lisboa: Edições 70, 2007, 223 p. 
BARLACH, Lisete. Book Review of Larsson, Ulf (Ed) (2006), Cultures of creativity. Creativity and Innovation Management, v. 17, n. 1, p. 90-91, 2008.

BARLACH, Lisete. O que é resiliência humana? Uma contribuição para a construção do conceito. Dissertação (Mestrado) - Instituto de Psicologia, Universidade de São Paulo, São Paulo, 2005.

BARTOLI, Jean. Espiritualidade na dissociedade supercapitalista: impasses e alternativas. Tese (Doutorado) - Pontifícia Universidade Católica de São Paulo, São Paulo, 2008.

BAUDRILlard, Jean. Curso Política de Negócios. São Paulo: Fundação Getúlio Vargas, s.d. (Apostila).

BAUDRILLARD, Jean. (1974). O sistema dos objetos. São Paulo: Perspectiva, 2000.

BAUDRILLARD, Jean. (1981). A sociedade de consumo. Lisboa: Edições 70, 2005.

BAXTER, Brian. The transcendence of alienation and estrangement in organizations: the quest for self-actualization. In: Brian Baxter: Alienation and authenticity. London: Tavistock Publications, 1982, p. 164 - 188. 
BENDASSOLLI, Pedro F.; WOOD JR., Thomaz; KIRSCHBAUM, Charles; PINA, E.; CUNHA, Miguel. Indústrias criativas: definição, limites e possibilidades. Revista de Administração de Empresas, v. 49, n. 1, jan./mar. 2009, p. 10 -18.

BENJAMIN, Walter. (1936). A obra de arte na era de sua reprodutibilidade técnica. In: ADORnO, T. et al. Teoria de cultura de massa. São Paulo: Paz e Terra, 2000, p. 221254.

BILTON, Chris. Management and creativity. Hoboken, NJ: Blackwell Publishing, 2007.

BODEN, Margaret. Dimensions of creativity. Boston: MIT Press, 1999.

BONO, Edward. Lateral thinking. New York: Perennial Library, 1990.

BURRELL, Gibson; MORGAN, Gareth. Sociological paradigms and organizational analysis. Heinemann, London, 1979. p. 1-37.

BUSCH, Lawrence. The moral economy of grades and standards. Journal of Rural Studies, v. 16, n. 3, p. 273-283, July 2000.

CARDON, Melissa S.; WINCENT, Joakim; SINGH, Jagdip; DRNOVSEK, Mateja. The nature and experience of entrepreneurial passion. Academy of Management Review, v. 34, n. 3, p. 511-532, 2009. 
CARPEAUX, Otto Maria. Uma nova história da música. São Paulo: Ed. Tecnoprint, 1958.

CETRANS Centro de Educação Transdisciplinar. Disponível em: <wwww.cetrans.com.br>. Acesso em: 15 mar. 2009.

CHAUÍ, Marilena. Convite à filosofia. São Paulo: Ática, 1997.

CHAUÍ, Marilena. Introdução à história da filosofia: dos pré-socráticos a Aristóteles. São Paulo: Brasiliense, 1994. v. 1.

COLLIER, Lindsay E. The Whack-a-mole theory. [S. 1.]: Wham Books, 1997. 162 p.

COUGER, J. Daniel; HIGGINS, Lexis F.; McINTYRE, Scott C. Differentiating creativity, innovation, entrepreneurship, intrapreneurship, copyright and patenting for I. S. product / process. System Sciences. In: PROCEEDINGS OF THE $23^{\text {RD }}$ ANNUAL HAWAII INTERNATIONAL CONFERENCE, 1995, p. 370-379. v. 4.

DE CHARMS, Richard. Personal causation. New York: Academic Press, 1968.

DE MASI, Domenico. Criatividade e grupos criativos. Rio de Janeiro: Sextante, 2003.

DRUCKER, Peter. Inovação e espírito empreendedor: práticas e princípios. Tradução de Carlos J. Malferrari. São Paulo: Pioneira, 1985. 
FERREIRA, Aurélio Buarque de Holanda. Novo dicionário da língua portuguesa. Rio de Janeiro: Nova Fronteira, 19--.

FIORINI, Hector Juan. Criatividade: dinamismos fundantes de um sistema no psiquismo humano. In: Estruturas e abordagens em psicoterapias psicanalíticas. Tradução de Cláudia Berliner. São Paulo: Martins Fontes, 2004.

FIORINI, Hector Juan. Teoria e técnica de psicoterapias. Rio de Janeiro: Francisco Alves, 1995. $233 \mathrm{p}$.

FREUD, Sigmund. (1908). On creativity and the unconscious (a difficulty of psychoanalysis). New York: Harper Collins, Jan. 1976.

GARDNER, Howard. Mentes que criam. Porto Alegre: Artes Médicas, 1996.

GARGIONI, Luiz A.; PLONSKI, Guilherme A.; LOURENÇÃO, Paulo T. M. Fatores críticos de sucesso para modelagem de parques tecnológicos privados no Brasil. In: XI SEMINÁRIO LATINO-AMERICANO DE GESTIÓN TECNOLÓGICA, Salvador, Bahia, 25 a 28 outubro 2005.

GEORGSDOTTIR, Asta S.; GETZ, Isaac. How flexibility facilitates innovation and ways to manage it in organizations. Creativity and Innovation Management, v. 13, n. 3, Sept. 2004, p. 166-175. 
GLOVER, John; RONNING, Royce; REYNOLDS, Cecil. Handbook of creativity. New York: Plenum Press, 1989.

HABERMAS, Jürgen. O futuro da natureza humana: a caminho de uma eugenia liberal? São Paulo: Martins Fontes, 2004.

HAMEL, Gary. The why, what and how of management innovation. Harvard Business Review, Feb. 2006, p. 1-19.

HANER, Udo-Ernst. Spaces for creativity and innovation in two established organizations. Creativity and Innovation Management, v. 14, n. 3, p. 288-298, Sept. 2005.

HIRSCH, Paul. Processing fads and fashions: an organization-set analysis of cultural industries system. American Journal of Sociology, v. 77, n. 4, 1972, p. 639 - 659.

HLAVACEK, Jim; MAXWELl, Craig; WILLIAMS JR., Jimmy. Learn from new product failures. ResearchTechnology Management, Vol. 52, n. 4, July/Aug. 2009, p. 31-39.

HOFSTEDE, Geert. Cultures and organizations: software of the mind. NY: McGrawHill, 1997, 279 p.

HUIZINGA, Johan. What play is. Parabola, p. 59-63, Fall 1996.

JEANES, Emma L. Resisting creativity, creating the New. A Deleuzian perspective on creativity. Creativity and Innovation Management, v. 15, n. 2, 2006, p. 127 - 134. 
JULLIER, Laurent. Qu'est-ce qu'un bom film? [S. 1.]: La Dispute.

KAMOTO, Cleusa Kazue. Três vértices da criatividade segundo Winnicott: o potencial, a experiência e a atmosfera criativa. Boletim de Psicologia, v. 50, n. 112, p. 75-84, 2000.

KAO, John. Jamming: The art and discipline of business creativity. New York: Harper Collins Publishers, 1996.

KAUFMANN, Geir. Two kinds of creativity - but which ones? Creativity and Innovation Management, v. 13, n. 3, Sept. 2004, p. 154 - 165.

KIRTON, Michael. Adaptors and innovators: A description and measure. Journal of Applied Psychology, v. 61, n. 5, p. 622-629, 1976.

KIRTON, Michael. (Ed.). Adaptors and innovators. New York: Routledge, 1989.

KOESTLER, Arthur. Act of creation. London: Penguin Books, 1964.

KOFFKA, Kurt. Princípios da psicologia da gestalt. São Paulo: Cultrix, 1975. 703 p.

KUHN, Thomas S. A estrutura das revoluções científicas. São Paulo: Perspectiva, 1962.

KURATKO, Donald F. Entrepreneurship education: Emerging trends and challenges for the 21st century. Coleman Foundation White Papers Series for the U.S. Association of 
Small Business \& Entrepreneurship, 2003. Disponível em: $<$ http://www.unm.edu/ asalazar/Kauffman/Entrep_research/e_ed.pdf $>$. Acesso em: 05 maio 2008.

LAPIERRE, Jozée; GIROUX, Vicent-Pierre. Creativity and work environment in a HighTech Context. Creativity and Innovation Management, v. 12, n. 1, p. 11-23, Mar. 2003.

LARSSON, Ulf. (Ed). Cultures of creativity. Sagamore Beach, Massachusetts: Watson Publishing International \& The Nobel Museum, 2005. 240 p.

LASH, Scott. Capitalism and metaphysics. Theory, Culture \& Society, v. 24, n. 5, p. 126, 2007.

LATNER, J. America's Protean Creativity: Gestalt Therapy and Creative License - essay and book review. International Gestalt Journal, v. 28, n. 2, p. 67-122, 2003.

LEWIS, Richard. Time is a child playing. Parabola, p. 56-58, Fall 1996.

LOWEN, Alexander. Prazer: uma abordagem criativa da vida. 7. ed. São Paulo: Summus, 1984.

LUBART, Todd. Creativity across cultures. Palestra proferida no II International Creativity \& Innovation Management Community Meeting. Buffalo, NY: PROCEEDINGS OF II INTERNATIONAL CREATIVITY \& INNOVATION MANAGEMENT COMMUNITY MEETING, 2008. 
LUBART, Todd. Psicologia da criatividade. Porto Alegre: Artmed, 2007. 192 p.

MALVEZZI, Sigmar. Desarrollo organizacional. 2008. (Manuscrito não publicado)

MARX, Karl. O capital (Crítica da Economia Política) (1867). Livro I - Processo de produção do capital, vol. I - Capítulo I - A mercadoria. Rio de Janeiro: Civilização Brasileira, 1980, $6^{\text {a }}$ edição.

MASLOW, Abraham Harold. The farther reaches of human nature. New York: Viking Press, 1971.

MAY, Rollo. A coragem de criar. Rio de Janeiro: Nova Fronteira, 1975. 143 p.

McCLELLAND, David C. The achieving society. Princeton, NJ: D. Van Nostrand Company, 1961.

McCLELLAND, David C.; ATKINSON, John W.; CLARK, Russel A.; LOWELL, Edgar C. The achievement motive. New York: Appleton Century Crofts, 1953. 384 p.

MICHAELIS, Henriette. Novo Michaelis: dicionário ilustrado. São Paulo: Melhoramentos, 1979.

MILLER, Blair; VEHAR, Jonathan; FIRESTIEN, Roger. Creativity unbound. 3. ed. Buffalo, NY: Innovation Resources, 2001. 
MUMFORD, Michael D.; BLAIR, Cassie; DAILEY, Lesley; LERITZ, Lyle E.; OSBURN, Holly K. Errors in creative thought: Cognitive biases in a complex processing activity. Journal of Creative Behavior, v. 40, n. 2, p. 75-110, Second Quarter 2006.

NACHMAMOVITCH, Stephen. Ser criativo: o poder da improvisação na vida e na arte. São Paulo: Summus, 1993.

NEILSON, Louise. Mediating with Picasso: creativity in conflict resolution. 2008. (Unpublished manuscript)

NICHOLSEN, Shierry W. Book Review of Hagman, George (2005) Aesthetic experience: Beauty, creativity and the search for the ideal, $168 \mathrm{pp}$. International Journal of Psychoanalysis, v. 87, p. 1737-1740, 2006.

OLIVEIRA, Marcos de; MARQUES, Fabrício. Nascedouro de negócios. Pesquisa FAPESP, n. 145, p. 68-75, mar. 2008.

OSBORN, A. F. O poder criador da mente. São Paulo: IBRASA, 1965.

OSTROWER, Fayga. Criatividade e processos de criação. Rio de Janeiro: Imago, 1977. $187 \mathrm{p}$.

PEIPERL, Maury; ARTHUR, Michael; ANAND, N. Thinking creatively about careers: The use of metaphor. In: Career creativity. New York: Oxford University Press, 2002. 
PEREIRA, Isidoro. (1951). Dicionário grego - português e português - grego. Braga, Portugal: Livraria Apostolado da Imprensa, 1990. 1054 p.

PIAGET, Jean. Possível e necessário. Porto Alegre: Artes Médicas, 1985. 2 v.

PIAGET, Jean. Criatividade. In: VASCONCELOS, Mário Sérgio. (Org.). Criatividade. São Paulo: Moderna, 2001.

PLONSKI, Guilherme Ary. Mantras da Inovação. In: Maria Tereza Fleury e Afonso Carlos Correa Fleury (org.) Política Industrial 2. São Paulo: Publifolha, 2004, p. 93-118.

PLONSKI, Guilherme Ary. Inovação: como vencer esse desafio empresarial. São Paulo: Clio Editora, 2006 (Resenha).

PLONSKI, Guilherme Ary. Anotações de aula "Habitats de Inovação" ministrada no curso de graduação em Sistemas de Informação, disciplina "Empreendedores em Informática”, ministrada no campus da USP Leste, 01/12/2008.

RANK, Johannes; PACE, Victoria L.; FRESE, Michael. Three avenues for future research on creativity, innovation and initiative. Applied Psychology, an International Review, v. 53, n. 4, p. 518-528, 2004.

REICH, Wilhelm. A função do orgasmo. São paulo: Brasiliense, 1974. 
RIBOT, Theodule Armand. (1906). Essay on the creative imagination. New York: Arno Press, 1973. Translation from the French by Albert H. N. Baron, 370 pp. (First edition, 1906).

RINDOVA, Violina; BARRY, Daved; KETCHEN JR., David J. Entrepreneuring as emancipation. Academy of Management Review, v. 34, n. 3, p. 477-491, 2009.

RODRIGUES, Suzana Braga. De fábricas a lojas de conhecimento. In: FLEURY, Maria T. Leme; OLIVEIRA Jr., Moacir de Miranda. Gestão estratégica do conhecimento: integrando aprendizagem, conhecimento e competências. São Paulo: Atlas, 2001. 349 p.

ROGERS, Carl R. Toward a theory of creativity. In: ANDERSON, H. H. (Ed.). Creativity and its cultivation. New York: Harper \& Row, 1959.

ROTHENBERG, David. Spontaneous effort. Parabola, p. 7-12, Fall 1996.

SASSENBERG, Kai; MOSKOWITZ, Gordon. Don't stereotype, think differently! Overcoming automatic stereotype activation by mindset priming. Journal of Experimental Social Psychology, v. 41, p. 506-514, 2005.

SCHAFFER, Simon. Caracterizando a descoberta. In: BODEN, Margaret. Dimensões da criatividade. Boston: MIT Press, 1999. 
SCHEIN, Edgard H. Organizational culture and leadership. San Francisco: JosseyBass, 2004.

SHAPIRO, Carl. Navigating the patent thicket: cross licenses, patent pools and standard setting. In: Adam B. Jaffe, Josh Lerner and Scott Stern. Innovation Policy and the economy. Boston: MIT Press, 2001, p. $119-150$.

SHYNIASHIKY, Gilberto. Cultura organizacional. São Paulo: Fundação Instituto de Administração, 2004. (Apostila do Curso de Gestão da Cultura e da Mudança Organizacional)

SMITH, Edward W. L. Art, artists and the Gestalt approach: an introduction. The International Gestalt Journal, v. 30, n. 2, p. 1-26, Fall 2007.

SOOSAY, Claudine; HYLAND, Paul. Exploration and exploitation: the interplay between knowledge and continuous innovation. International Journal of Technology Management, v. 42, n. 1/2, p. 20-35, 2008.

STERNBERG, Robert J. The theory of successful intelligence. Revista Interamericana de Psicología, v. 39, n. 2, p. 189-202, 2005.

STERNBERG, Robert J. Wisdom, intelligence, and creativity synthesized. New York, NY: Cambridge University Press, 2003. 
STERNBERG, Robert J. What is the common thread of creativity? American Psychologist, v. 56, n. 4, p. 360-362, 2001.

STERNBERG, Robert J. Handbook of creativity. New York: NY: Cambridge University Press, 1999.

STERNBERG, Robert J.; O’Hara, Linda A. \& Lubart, Todd I. Creativity as investment. California Management Review, v. 40, n. 1, Fall 1997, p. 8 - 22.

STYHRE, Alexander. The element of play in innovation work: the case of new drug development. Creativity and Innovation Management, v. 17, n. 2, 2008, p. 136-146.

TARDE, Gabriel. Economic psychology. Economy and Society, v. 36, n. 4, p. 614-643, 2007.

TAYLOR, Frederick W. Princípios da administração científica. Rio de Janeiro: DASP, 1948.

THRIFT, Nigel. Re-inventing invention: new tendencies in capitalist commodification. Economy and Society, v. 35, n. 2, p. 279-306, May 2006.

TORRANCE, E. Paul. The search for satori \& creativity. Buffalo, NY: Creative Education Foundation, 1979. 
TORRANCE, E. Paul. Pode-se ensinar criatividade? São Paulo: Ed. Pedagogica e Universitaria, $1974.50 \mathrm{p}$.

TORRANCE, E. P. Desarrollo de la creatividad del alumno. Buenos Aires: Livreria del Colegio, 1970.

TORRINHA, Francisco. Dicionário português - latino. Porto, Portugal: Ed. Domingos Barreira, 1939, 1129 p.

TSCHANG, F. Ted. Balancing the tensions between rationalization and creativity in the video games industry. Organization Science, v. 18, n. 6, p. 989-1005, Nov./Dec. 2007.

UNSWORTH, Kerrie. Unpacking creativity. Academy of Management Review, v. 26, n. 2, p. 286-297, 2001.

VASCONCELLOS, Liliana. Gestão da inovação e competitividade. São Paulo: Fundação Instituto de Administração, 2008. (Apostila)

WECHSLER, Solange Múglia. Criatividade: descobrindo e encorajando. Campinas, SP: Editorial Psy, 1993.

WEST, M. A.; FARR, J. L. Innovation and creativity at work: psychological and organizational strategies. Chichester: John Wiley, 1990. 
WEST, M. A.; ANDERSON, N. R. Innovation in top management teams. Journal of applied psychology, 81, 1996, p. 680 - 693.

WEST, Michael A. Sparkling fountains or stagnant ponds: An integrative model of creativity and innovation implementation in work groups. Applied Psychology: An International Review, v. 51, n. 3, p. 355-424, 2001.

WINNICOTT, D. W. O brincar e a realidade. Rio de Janeiro: Imago, 1975.

ZIBARRAS, Lara D.; PORT, Rebecca L.; WOODS, Stephen A. Innovation and the "dark side" of personality: Dysfunctional traits and their relation to self-reported innovative characteristics. Journal of Creative Behavior, v. 42, n. 3, Third Quarter 2008, p. 201215. 